\title{
EL IMPACTO DE LA GRAN RECESIÓN SOBRE LOS MIGRANTES DOMINICANOS
}

\section{Jaime Aristy-Escuder ${ }^{*}$}

Resumen: El objetivo del presente estudio es identificar y analizar cuáles han sido los principales efectos de la Gran Recesión, en particular la registrada en los Estados Unidos -incluyendo a Puerto Rico- y España, sobre los niveles de vida de la comunidad dominicana en esos países. Se evaluará cómo los dominicanos en el exterior están reaccionando al impacto de la crisis (e. g., consumo e inversión) y se analizará el impacto de la recesión sobre las remesas enviadas a la República Dominicana.

Abstract: The purpose of this study is to identify and analyze which were the principal effects of the Great Recession, in particular in the United States -including Puerto Rico- and Spain, on the wellbeing of Dominican communities in those countries. The reaction of Dominicans living abroad will be assessed and the impact of the recession on remittances sent to the Dominican Republic will be analyzed.

\footnotetext{
* Profesor del INTEC. Email: jaimearisty@gmail.com
} 


\section{Introducción y objetivos}

La República Dominicana es un país con una gran cantidad de emigrantes. Alrededor del 15\% de los dominicanos vive en el extranjero, población que mantiene un continuo contacto con sus familiares que residen en el territorio nacional. Las remesas constituyen una prueba fehaciente de esas fuertes y continuas relaciones. Cada año, la comunidad dominicana en el exterior envía remesas por un monto superior a los 3,100 millones de dólares $(5.3 \%$ del PIB), preponderantemente desde los Estados Unidos y España. ${ }^{1}$ Ese dinero se inserta a la economía dominicana, a través de un incremento del consumo y, en menor medida, de la inversión. ${ }^{2}$

La crisis financiera internacional, que posteriormente desembocó en la Gran Recesión, deterioró la capacidad de generar empleos en los países desarrollados. En los Estados Unidos -incluyendo a Puerto Rico- y en España, principales polos de atracción de los dominicanos emigrantes, la tasa de desempleo alcanzó el 10\% y $27 \%$, respectivamente. El aumento del desempleo repercutió negativamente sobre la capacidad de los dominicanos de insertarse o mantenerse en el mercado laboral con el mismo nivel de ingreso, deteriorando la calidad de vida de los emigrantes y de sus familiares que residen en territorio nacional.

Debe resaltarse que los dominicanos en el extranjero constituyen un segmento social muy vulnerable. Los datos revelan que los dominicanos ocupan principalmente puestos de trabajo de poca calificación y, en consecuencia, de baja remuneración. Esto produce

\footnotetext{
1 De acuerdo a la Encuesta Nacional de Ingresos y Gastos de los Hogares, alrededor del $72 \%$ de las remesas proviene de los Estados Unidos; el 10\% de España; y el 6.5\% de Puerto Rico.

2 Se estima que alrededor del $60 \%$ de los ingresos por remesas se utilizan para financiar necesidades básicas y el 17\% para el pago del servicio de educación.
} 
que la incidencia de la pobreza en los países receptores sea superior entre los dominicanos que en el promedio de la población. ${ }^{3}$

La crisis económica internacional, que se concentró inicialmente en las actividades de construcción, manufactura y finanzas, redujo la capacidad de generación de ingresos de los dominicanos que trabajan en esas actividades. El descenso de las remuneraciones laborales es un factor que se manifiesta en el patrón de consumo de bienes y servicios y en la disminución de las remesas, afectando negativamente a los familiares que residen en el territorio dominicano. Entre 2008 y 2010, las remesas familiares recibidas en la República Dominicana descendieron en un $7 \%$.

El objetivo del presente estudio es identificar y analizar cuáles han sido los principales efectos de la Gran Recesión, en particular la registrada en los Estados Unidos y España, sobre los niveles de vida de la comunidad dominicana en esos países. Se evaluará cómo los dominicanos en el exterior están reaccionando al impacto de la crisis (e. g., consumo e inversión) y se analizará el impacto de la crisis sobre las remesas enviadas a la República Dominicana. El conocimiento de cómo los dominicanos han reaccionado a la crisis económica es indispensable para que puedan adoptarse medidas o influir en el diseño de políticas públicas que tiendan a mejorar sus condiciones de vida, tanto en el exterior como en el territorio nacional.

Para obtener los resultados se aplicó una encuesta ${ }^{4}$ a dominicanos residentes en los Estados Unidos -incluyendo a Puerto Rico- y en España para determinar el impacto de la crisis económica sobre su acceso a un puesto de trabajo y, en consecuencia, sobre su nivel de ingreso laboral. Se aplicaron 381 cuestionarios, 178 en

\footnotetext{
3 Véase Aristy-Escuder (2008).

4 El cuestionario aplicado puede obtenerse en https://dl.dropboxusercontent.com/u/ 57667013/Cuestionario\%20Emigrantes \%20dominicanos $\% 20$ revisado $\% 20$ final.pdf y la data puede requerirse directamente al correo del autor jaimearisty@gmail.com
} 
las ciudades de Nueva York y New Jersey (Estados Unidos), 126 en Madrid (España) y 77 en San Juan de Puerto Rico. La información de esa encuesta se presenta en un análisis descriptivo de las variables que permiten relacionar la crisis económica y el bienestar de los dominicanos emigrantes. Además, esos datos posibilitaron la elaboración de modelos econométricos que cuantifican el impacto de la desaceleración de la economía de los Estados Unidos y de España en los ingresos de los dominicanos y, por lo tanto, en su capacidad de envío de remesas hacia la República Dominicana.

La selección de las ciudades donde se aplicaron los cuestionarios tuvo en consideración que los países de destino donde se concentra la migración dominicana son los Estados Unidos -incluyendo a Puerto Rico- y España. En el censo del año 2000 había en los Estados Unidos 799,768 dominicanos, concentrados principalmente en la ciudad de Nueva York. ${ }^{5}$ Se estima que en 2010 esa población alcanzó una cifra de 1.5 millones, de los cuales el 57\% nació en la República Dominicana. ${ }^{6}$ En el caso de España, la migración dominicana se incrementa significativamente en la última década del siglo pasado. A partir de 1990 comenzó a registrarse un aumento sistemático de la población dominicana, principalmente mujeres, admitidas a trabajar en territorio español. Se estima que los dominicanos en el año 2004 ascendían a la cifra de 65,777 personas, concentrándose el $70.7 \%$ en Madrid y Barcelona. ${ }^{7}$ Hacia el año 2010 se tenía empadronados en el territorio español a 135,734 dominicanos.

Las personas entrevistadas se abordaron de manera aleatoria en distintos puntos de las ciudades de Nueva York, New Jersey, Madrid y San Juan, con el objetivo de que la muestra fuese representativa de la comunidad dominicana. La aleatoriedad de la

\footnotetext{
5 En 2010, el 48\% de los dominicanos en los Estados Unidos vivía en Nueva York y $13.6 \%$ residía en New Jersey.

6 Pew Hispanic Center (2012), pp. 1-2.

7 Véase Báez-Evertsz (2001) citado por Aristy-Escuder (2008).
} 
muestra y su tamaño (381 observaciones) garantiza que las estimaciones tengan una confiabilidad del $95 \%$, con un error máximo permitido de entre $5 \%$ y $6 \%$.

En la segunda sección se presenta una descripción de las causas y consecuencias de la crisis económica en los Estados Unidos y en España, conocida como la Gran Recesión. Se analiza el por qué se pasa de un período de rápido crecimiento a uno de contracción y de destrucción de empleo. Se describen las políticas macroeconómicas aplicadas para enfrentar la crisis económica y su impacto sobre el bienestar de la población, en particular sobre los inmigrantes.

En la tercera sección se describe el caso de los dominicanos en los Estados Unidos -incluyendo a Puerto Rico- y España. Se presentan las principales hipótesis que son evaluadas a través de la aplicación de modelos microeconométricos a los datos obtenidos de la encuesta realizada a los dominicanos residentes en las ciudades de Nueva York, New Jersey, Madrid y San Juan de Puerto Rico.

El estudio verificó que la crisis económica redujo las posibilidades de obtener un empleo e hizo que se incrementase la percepción de perder el empleo entre los emigrantes dominicanos residentes en Estados Unidos, España y Puerto Rico. La crisis económica deterioró la calidad del empleo, expresada en la disminución del ingreso por hora y en una ligera caída de las horas trabajadas por semana, lo cual se manifestó en un menor ingreso promedio en términos reales en 2011 con relación al 2008.

Los resultados revelan que la probabilidad de estar empleado depende (de manera cuadrática) de la edad. La mujer tiene menor probabilidad de estar empleada. El tiempo de residencia influye positivamente en la capacidad de insertarse en el mercado laboral. La educación no tiene una influencia concluyente sobre la probabilidad de estar empleado. Además, se concluye que es más fácil estar empleado en los Estados Unidos y en Puerto Rico que en 
España. Esto se explica por la mayor flexibilidad del mercado laboral norteamericano.

También se estimaron modelos que cuantifican los determinantes de la cantidad de horas trabajadas. Se obtuvo como resultado que ser mujer y la cantidad de hijos influye negativamente sobre la cantidad de horas trabajadas por semana. El nivel de educación -medida por la variable que distingue entre calificados y no calificados (con educación igual o superior a universitaria) - no resultó ser significativo.

La Gran Recesión, al disminuir el ingreso promedio real de los dominicanos, provocó cambios en el patrón de consumo e inversión. Se estimaron modelos econométricos que verificaron el impacto de la crisis sobre el consumo de bienes perecederos y las inversiones. Las personas que declararon no estar trabajando al momento de la entrevista reconocieron en mayor proporción haber realizado cambios en su patrón de consumo. La restricción crediticia impactó sobre las decisiones de los dominicanos. Aquellos con mayor preocupación de perder su empleo fueron más propensos a modificar su patrón de consumo ante la Gran Recesión. La población residente en España fue la más afectada.

Ante la Gran Recesión, los encuestados afirman que ahora es más difícil lograr el sueño del migrante de conseguir un trabajo estable, vivienda propia y ayudar a la familia. No obstante, la mayoría de los dominicanos residentes en el exterior declara que, a pesar de la crisis económica, no desea retornar al país de origen.

Como aporte adicional al conocimiento del migrante dominicano se estimó el retorno a su educación -ecuación de Mincer- que reciben en el país receptor. Los resultados revelan que por cada año de escolaridad adicional el ingreso se incrementa en 5.7\%. También se observa el típico patrón de discriminación laboral en contra de la mujer, la cual percibe una remuneración $21.7 \%$ menor que el hombre. Los emigrantes dominicanos residentes en España 
y Puerto Rico reciben un menor nivel de ingreso que sus pares en los Estados Unidos.

La crisis económica redujo el monto de remesas que envían a sus familiares residentes en la República Dominicana. Se determinó que la probabilidad de enviar remesas depende del estatus laboral. Los dominicanos residentes en España y Puerto Rico tienen más probabilidad de enviar remesas a sus familiares. Se estimaron modelos econométricos que verificaron que el volumen agregado de las remesas que recibe la economía dominicana depende del ciclo económico de los Estados Unidos y de España.

\section{Causas y consecuencias de la Gran Recesión}

\subsection{Estados Unidos}

Uno de los grandes logros de Alan Greenspan como presidente de la Reserva Federal entre 1987 y 2006 fue la estabilidad macroeconómica. ${ }^{8}$ Ese período, caracterizado por la baja volatilidad de la tasa de crecimiento económico y de la tasa de inflación, se denominó la Gran Moderación. Esa estabilidad se tradujo en una significativa disminución de la prima de riesgo que, junto a políticas monetarias relativamente flexibles, redujeron las tasas de interés de corto y largo plazo. Lamentablemente, esa situación creó incentivos que acentuaron el endeudamiento de las instituciones financieras y de los agentes económicos privados. ${ }^{9}$

Los primeros años de la década del 2000 se caracterizaron por una gran disponibilidad de crédito a tasas de interés relativamente

8 Véase Bernanke (2013) para una exposición sobre la estabilidad macroeconómica registrada bajo la presidencia de Greenspan en la Reserva Federal.

9 Bean (2009) afirma que el endeudamiento de las instituciones financieras se realizó fuera de libros para evitar los requerimientos de capital adicional, mediante el uso de instrumentos financieros altamente complejos. 
bajas. ${ }^{10}$ Esto permitió a muchos agentes económicos, algunos con mala calificación crediticia (subprime), obtener financiamientos para adquirir viviendas y a otros obtener préstamos colocando de garantías sus viviendas. ${ }^{11}$ La banca minimizó la importancia de la mala calidad de esos créditos, pues el precio de las viviendas subía exponencialmente ${ }^{12} \mathrm{y}$, en el caso de los Estados Unidos, desde 1930 no se había registrado un descenso en el precio de los bienes raíces. Además, la banca tomó esos préstamos y diseñó instrumentos financieros derivados, que empaquetaban los préstamos hipotecarios y los aseguraba para mejorar su nivel de calidad crediticia. ${ }^{13}$ Posteriormente los vendía a inversionistas institucionales e individuales, a precios que no reflejaban su verdadero nivel de riesgo, ${ }^{14}$ obteniendo liquidez suficiente para continuar realizando más préstamos hipotecarios a personas con un mal crédito.

Hasta ese punto todos los agentes económicos realizaban beneficios. Pero todo cambió cuando en el año 2006, los precios de las viviendas comenzaron a descender provocando que desde inicio

10 La Reserva Federal redujo entre 2001 y 2003 las tasas de interés para enfrentar la recesión, caracterizada por bajo crecimiento económico y débil creación de empleo.

11 En 20005 los propietarios de viviendas en los Estados Unidos tomaron prestados 750 billones de dólares colocando de garantía el valor de sus viviendas. Véase Keeley y Love (2010).

12 Bernanke (2013) afirma que entre finales de los años noventa y 2006 el precio de las viviendas en los Estados Unidos se incrementó en un 130\%. En Bean (2009) se presenta la evolución de los precios reales de las viviendas en España, el Reino Unido, Irlanda, Australia, Francia, los Estados Unidos, Suiza y Alemania. Solo en este último país el precio en 2007 era más bajo en términos reales que en 1980. Bernanke (2013) sostiene que existe una correlación estrecha entre el precio de las viviendas y la entrada de capitales. Esto explicaría el por qué los precios de las viviendas se incrementaron en España y no en Alemania, a pesar de tener la misma política monetaria.

13 La empresa aseguradora AIG vendía a los inversionistas de esos instrumentos financieros derivados permutas de incumplimiento crediticio (credit default swaps, CDS) mediante las cuales les prometía que les compensaría en caso de que perdiesen dinero por sus inversiones en obligaciones de deuda colateralizadas (Collateralised Debt Obligations, $C D O)$. Esto elevaba a AAA los instrumentos financieros que garantizaba.

14 Por lo tanto, esos títulos financieros estaban sobrevaluados, inflando ficticiamente el valor de los activos $-\mathrm{y}$ solvencia- de sus propietarios. 
de 2007 la deuda de muchos clientes -que estaban excesivamente endeudados- fuese superior al precio de sus viviendas, lo cual les llevó a incumplir con sus hipotecas. ${ }^{15}$ Las instituciones financieras ${ }^{16}$ y algunos fondos de inversión comenzaron a notar el deterioro de la capacidad de los títulos financieros de generar la liquidez suficiente para poder mantener los pagos a sus tenedores. Los tenedores de esos títulos percibieron que sus precios estaban sobrevaluados e iniciaron un proceso de desprendimiento, enviando sus precios hacia abajo, lo cual les generó severas pérdidas. Los compradores de esos títulos abandonaron el mercado debido a la incertidumbre con relación a la calidad de los mismos, ${ }^{17}$ aumentando todavía más las pérdidas de los tenedores.

La primera gran víctima producto del descenso del precio de los activos y de la iliquidez del mercado para los títulos respaldados por hipotecas fue el banco de inversión Bear Stearns en marzo de 2008..$^{18}$ En el tercer trimestre de 2008 quebraron varias instituciones financieras, algunas de las cuales fue necesario rescatar por su gran tamaño e importancia económica. En ese contexto, el 7 de septiembre de 2008 el gobierno estadounidense decidió tomar el control de las empresas hipotecarias Fannie Mae y Freddie Mac, para evitar su colapso total. ${ }^{19}$ Entre el 12 y el 15 de septiembre la aseguradora AIG trató de obtener un préstamo de Goldman Sachs y JP Morgan Chase por la suma de 70,000 millones de dólares para enfrentar pérdidas derivadas de sus permutas de incumplimiento crediticio.

15 Las hipotecas con atrasos o incumplimientos pasaron de un millón en 2007 a más de cinco millones en 2009, superando el 10\% del total. Véase Bernanke (2013).

16 Cuyos modelos de riesgo subestimaban el impacto de la reducción del precio de las viviendas sobre su nivel de solvencia.

17 Véase Akerlof (1970) para una exposición sobre el problema del “mercado para los limones" o de cómo la incertidumbre influye sobre el precio de los bienes.

18 El 16 de marzo de 2008 el banco J. P. Morgan Chase, con el respaldo de la Reserva Federal, compró a Bear Stearns evitando su colapso total.

19 El Congreso autorizó al Tesoro a garantizar todas las obligaciones de esas dos empresas, que se desprenden de sus operaciones de titularización de hipotecas. 
El 15 de septiembre, el banco de inversión Lehman Brothers ${ }^{20}$ quebró, provocando una gran destrucción de riqueza financiera. Ese mismo día Merrill Lynch, otro banco de inversión, fue adquirido por Bank of America. El 16 de septiembre el Banco de la Reserva Federal de Nueva York tomó el control de AIG, la empresa aseguradora más grande del mundo. El 26 de septiembre JP Morgan Chase adquirió partes de la empresa hipotecaria Washington Mutual. Wachovia, uno de los cinco grandes bancos en los Estados Unidos, fue adquirido por Wells Fargo el 3 de octubre.

La pérdida de riqueza financiera acentuó la crisis económica al disminuir el poder de compra de los consumidores norteamericanos, reduciéndose, en consecuencia, la capacidad de las empresas de mantener el mismo nivel de empleo. El colapso de los mercados de crédito, desembocó en una caída de los índices bursátiles, del crecimiento económico ${ }^{21}$ y del comercio a nivel mundial. A partir de ese momento comenzó el período denominado la Gran Recesión.

El impacto de la crisis financiera sobre el sector real en los Estados Unidos fue significativo. En 2008 y 2009, el PIB real descendió en $-0.34 \%$ y $-3.07 \%$, respectivamente. El empleo agregado se redujo en 8.5 millones de personas desde diciembre de 2007 a 2010, alcanzando la tasa de desempleo promedio un $9.3 \%$ en 2009 . La tasa de inflación en 2009 fue negativa en $-0.3 \%$, registrándose una brecha del producto -como porcentaje del PIB potencial- de - $6.1 \%$. La contracción de la actividad económica se tradujo en la disminución de la demanda de importaciones, contrayéndose el déficit de la cuenta corriente de 5.1\% del PIB en 2007 a un $2.7 \%$ del PIB en

\footnotetext{
20 El no rescate de Lehman Brothers es considerado como uno de los grandes errores de la Reserva Federal y del Tesoro estadounidense. Bernanke (2013), pp. 94-95, afirma que Lehman no fue rescatado porque era una firma insolvente y no tenía suficiente colateral para entregarlo como garantía a la Reserva Federal. "No teníamos una vía legal para salvar a Lehman."

21 Hall (2010).
} 
2009. A partir de 2010, la economía estadounidense comenzó a recuperarse, alcanzando la tasa de crecimiento económico un $2.39 \%$, pero la creación de empleo fue lenta, colocándose la tasa de desempleo promedio en 9.6\%.22 En el período 2011-2012 la tasa de crecimiento del PIB osciló alrededor del $2 \%$, reduciéndose gradualmente la tasa de desempleo hasta un $7.7 \%$ a inicios de 2013. ${ }^{23} \mathrm{La}$ crisis financiera incrementó significativamente el déficit de las finanzas públicas. El déficit del gobierno general pasó de un 2.7\% del PIB en 2007 a un 11.1\% del PIB en 2010. La deuda del gobierno general se incrementó de un $66.5 \%$ del PIB antes de la crisis a un 108.1\% del PIB en 2013.

\section{Gráfico $\mathbf{N} .^{\circ} 1$}

\section{Indicadores macroeconómicos ${ }^{24}$}

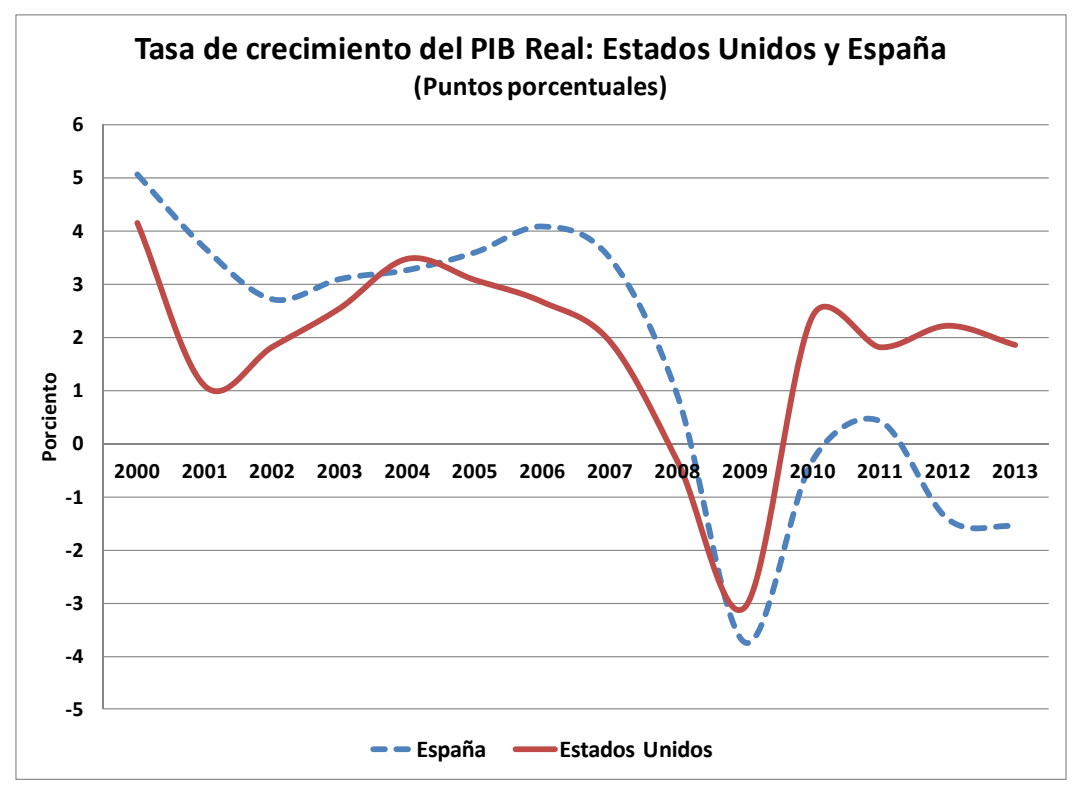

22 En octubre de 2010, la tasa de desempleo se colocó en un 10\%.

23 En agosto de 2013, la tasa de desempleo bajó a un 7.3\%, debido a la reducción de la población económicamente activa.

${ }^{24}$ Los datos presentados en estas gráficas fueron tomados de la base de datos del Fondo Monetario Internacional. 

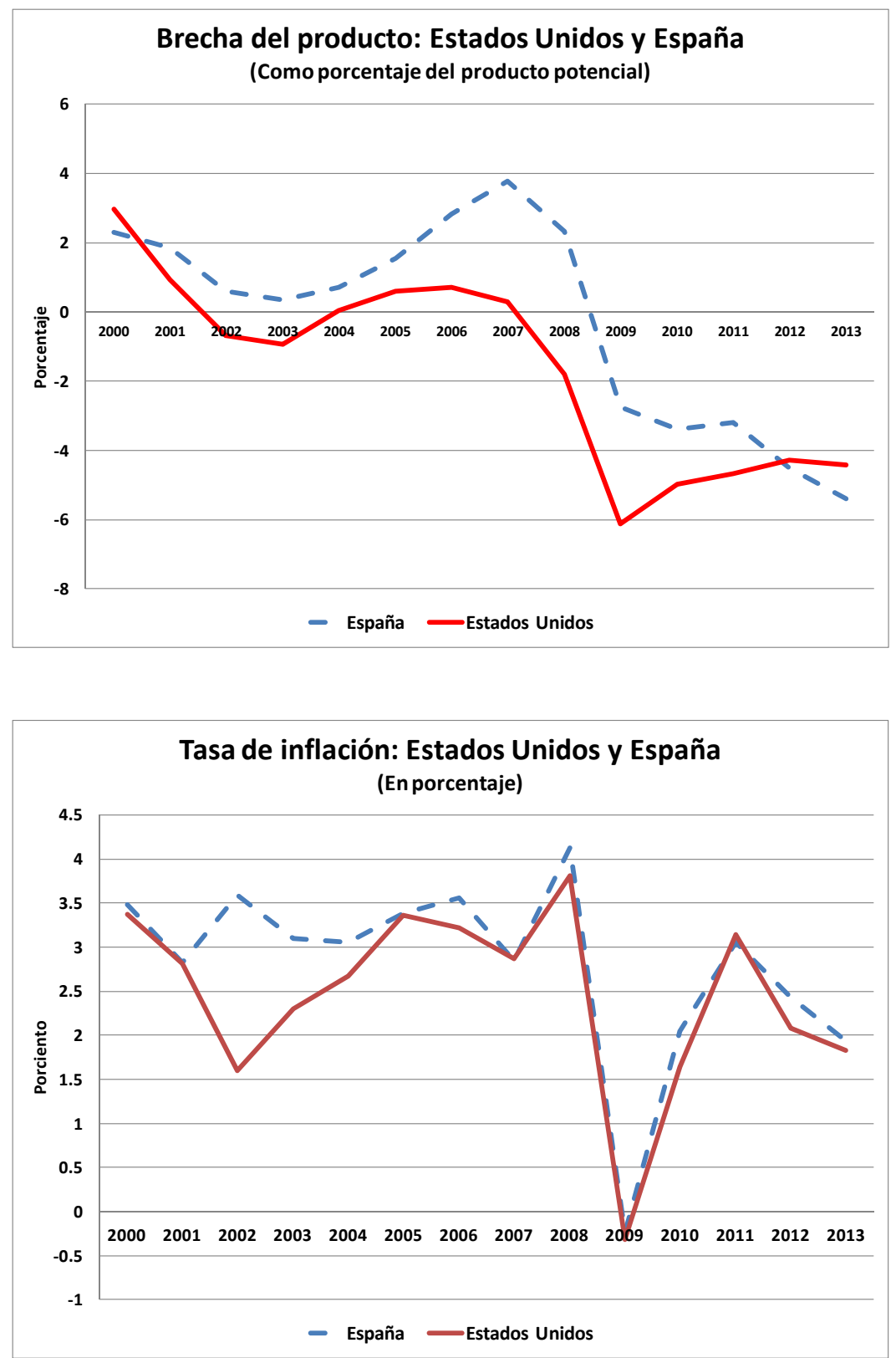
El impacto de la Gran Recesión sobre los migrantes dominicanos
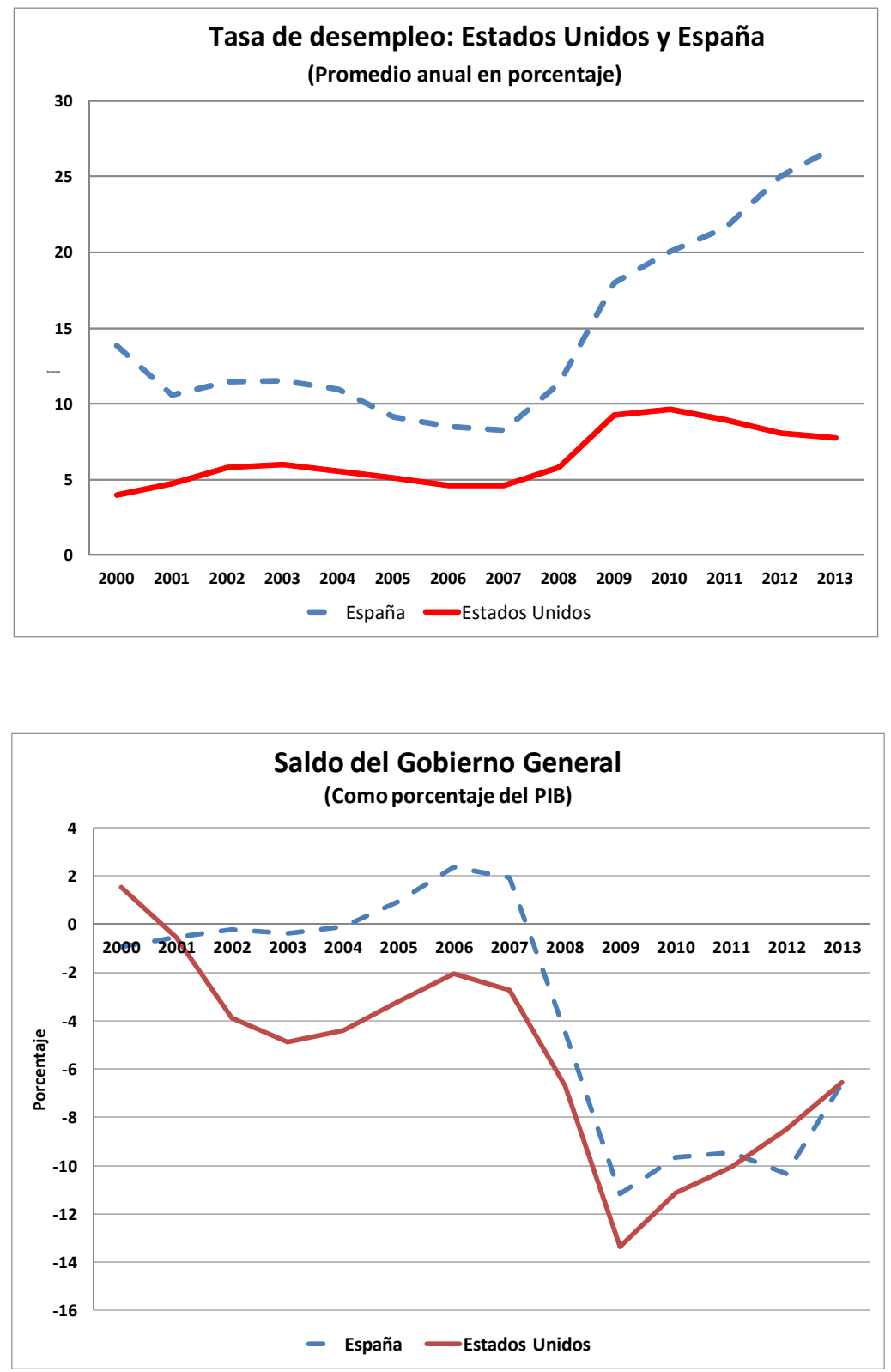

Ciencia y Sociedad 2015; 40(3): 477-563 489 


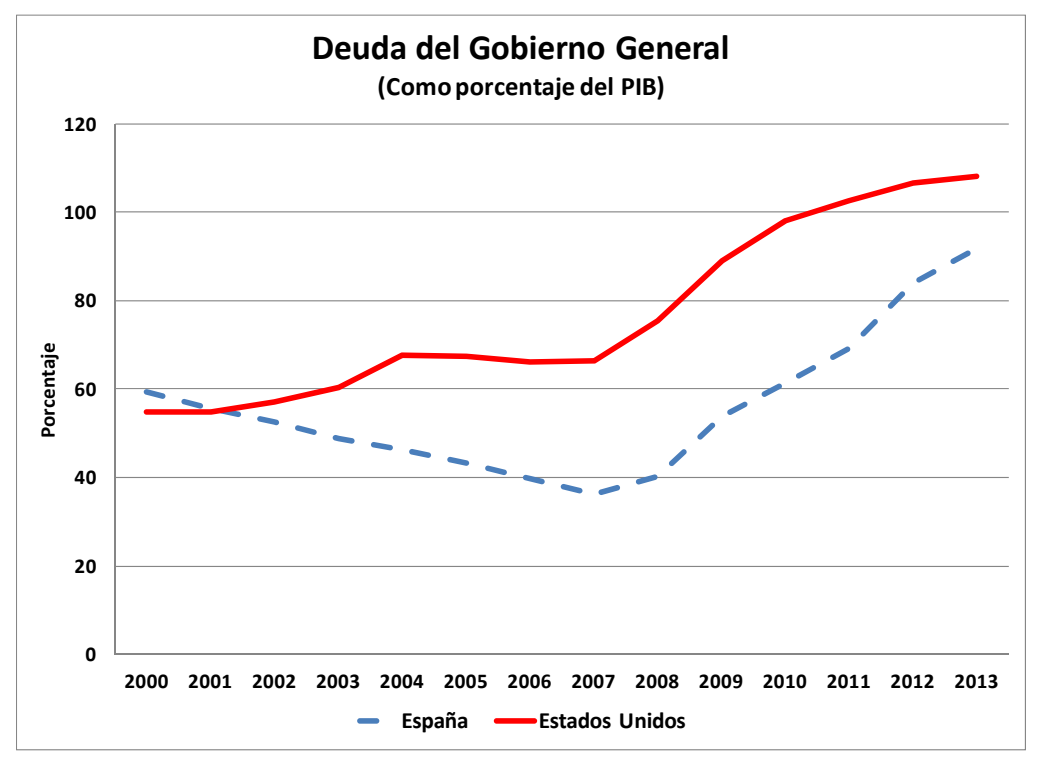

Existe evidencia que demuestra que la crisis financiera provocó severas disparidades en los Estados Unidos. Los sectores más afectados fueron construcción, manufactura y finanzas. Los estados más afectados por la explosión de la burbuja inmobiliaria fueron California, Florida, Nevada y Arizona. El colapso de la manufactura afectó en mayor medida a Ohio y Michigan. Y el descenso de las actividades financieras impactó más a Nueva York y Delaware. ${ }^{25}$

La pobreza extrema en los Estados Unidos subió de un 2.8\% en 2004 a un $4.8 \%$ en 2009-2010, situándose la pobreza en un 15\%, calculada con una línea de pobreza de 11,702 dólares de renta anual para un individuo y 23,201 dólares para una familia de cuatro. ${ }^{26}$

La crisis económica provocó mayor un impacto sobre los inmigrantes que sobre los nacidos en Estados Unidos. "Esto representa un

25 Véase Estevão y Tsounta (2011).

26 The Economist (2012), "In need of help", p. 22, November $10^{\text {th }}-16^{\text {th }}$ issue.

490 Ciencia y Sociedad 2015; 40(3): 477-563 
cambio respecto al pasado reciente, cuando los nacidos en Estados Unidos por lo general tenían mayor tasa de desempleo. El caso es complejo, con los inmigrantes menos calificados y los más educados experimentando el mayor aumento de la tasa de desempleo con relación a los nativos." 27 La tasa de desempleo entre los inmigrantes era 5.6 puntos porcentuales superior en el 2009 (9.7\%) de lo que era en el 2007. Mientras, la tasa de desempleo de los nativos se incrementó en 3.8 puntos porcentuales en el mismo período, llegando a un $8.6 \%$. Cabe resaltar que entre los inmigrantes que llegaron en 2006 o después, la tasa de desempleo en 2009 se colocó en un $13.3 \%$. Esto sugiere que la crisis del mercado laboral ha afectado más a los inmigrantes recién llegados al territorio estadounidense.

La tasa de desempleo entre dominicanos aumentó durante la Gran Recesión. En 2008, la tasa de desempleo entre los dominicanos era de 9.8\%. Dos años después, la tasa de desempleo subió a 15.3\%.

\subsection{España}

Entre 1994 y 2007, España alcanzó en promedio una tasa de crecimiento de un $3.7 \%$, superando tanto su tasa de crecimiento potencial $(3 \%)^{28}$ como el promedio de los países de la zona euro $(2.3 \%)$. Ese crecimiento se explica por acumulación de capital y el aumento de la población. La entrada de España a la Unión Económica y Monetaria ${ }^{29}$ eliminó la peseta y el riesgo de devaluación, reduciendo las tasas de interés promedio de corto plazo de 13.3\% en 1992 a $2.2 \%$ en 2005 . Ese comportamiento de las tasas de interés expandió

27 Véase Camarota y Jensenius (2009).

28 Hernández et al. (2011).

29 Que significó una política monetaria común y una moneda común, el euro, además de la coordinación de las políticas fiscales de sus miembros. La decisión de formar esa Unión fue tomada en 1991 por el Consejo Europeo en la ciudad de Maastricht, plasmándose posteriormente en el Tratado de Maastricht. 
el crédito, la inversión y el crecimiento económico. ${ }^{30} \mathrm{El}$ aumento de la población, provocado principalmente por la llegada de 3.6 millones de inmigrantes en edad de trabajar entre 2000 y 2007, fue el otro elemento que explica el ritmo de crecimiento del PIB registrado en ese período. ${ }^{31}$

Hacia finales de 2007, que marcó el comienzo de la crisis financiera internacional, España gozaba de una situación económica aparentemente buena. Su posición fiscal era excelente, pues las finanzas públicas -a diferencia de la mayoría de los países europeos ${ }^{32}$ arrojaban un superávit equivalente a un 1.9\% del PIB y la razón deuda pública-PIB era de apenas un 36.1\%.33 Sin embargo, el crecimiento económico por encima del potencial provocó que en el período 1994-2007 la tasa de inflación promedio anual (2.7\%) superase a la tasa de inflación de la zona euro, perdiendo competitividad. ${ }^{34}$ Dada esa variación de precios, la tasa de interés real se colocó en el entorno del $0 \%$, incentivando a los agentes económicos a adquirir y realizar inversiones en bienes raíces, en particular en viviendas. Eso provocó un boom del sector construcción ${ }^{35}$ y un aumento exponencial en el precio de los bienes raíces, alcanzando niveles de burbuja. ${ }^{36}$ Además, el crecimiento económico se fundamentó en un aumento de la demanda agregada interna -inversión

30 Véase De la Dehesa (2012). Véase en De Juan et al. (2013) una descripción de la gestión bancaria en España.

31 En 2010, el total de inmigrantes era de 5.7 millones de personas, representando un $15 \%$ de la población económicamente activa.

32 Los gobiernos de los países de la zona euro tenían en promedio un déficit equivalente a un $0.7 \%$ del PIB.

33 La deuda pública promedio de la zona euro ascendía a un 59\% del PIB. Italia, 103\%; Alemania, 64.9\%; Francia, 63.9\%; Portugal, 68.3\%; y Bélgica, 84.2\%.

34 De la Dehesa (2012).

35 De la Dehesa (2012) afirma que el sector construcción llegó a representar un 20\% del PIB, un $23 \%$ del empleo y $53 \%$ de la inversión.

36 Entre 1996 y 2007, el precio de las viviendas se incrementó en 11\% como promedio anual. 
en construcción, maquinarias y equipos y consumo privado-, traduciéndose ese excesivo nivel de demanda en un déficit creciente de la cuenta corriente que llegó a un 10\% del PIB en 2007. Ese déficit externo fue financiado principalmente por bancos alemanes, franceses y holandeses, aumentando la deuda privada con el exterior. Se estima que cuando inició la crisis en 2007, el stock de deuda privada bruta no consolidada, externa e interna, era de $405 \%$ del PIB. ${ }^{37}$ El nivel de crédito se situó en un $170 \%$ del PIB, teniendo como respaldo precios de bienes raíces excesivamente elevados. Cuando inició la crisis financiera internacional, la burbuja inmobiliaria española explotó y la banca entró en una severa crisis debido a la dificultad de conseguir financiamientos en Alemania y Francia, que obligó a los bancos españoles a incrementar sus tasas de interés para atraer depósitos y a reducir sus créditos.

El PIB español desaceleró su ritmo de crecimiento hasta situarse en un $0.9 \%$ en 2008 . El gobierno español decidió enfrentar esa desaceleración provocada por la reducción de los créditos mediante el aumento del gasto público. Las autoridades ejecutaron un amplio programa de pequeñas obras de infraestructura para enfrentar la desaceleración de la economía. Entre 2007 y 2009, las finanzas públicas pasaron de un superávit de un 1.9\% del PIB a un déficit de un 11.2\% del PIB, explicado ese deterioro por la combinación de un incremento de los gastos y una disminución de los ingresos tributarios. Las autoridades aplicaron posteriormente un programa de consolidación fiscal, compuesto por aumentos de impuestos y reducción de gastos corriente y de capital, que redujo sostenidamente el déficit del gobierno general hasta colocarlo en $6.6 \%$ del PIB. A pesar de esa disminución, la crisis financiera y el rescate de grandes instituciones financieras llevó la deuda pública de un 36.3\% del PIB en 2007 a un 91.8\% en 2013.

37 De la Dehesa (2012) señala que la deuda de los hogares era $88 \%$ del PIB, la deuda de las empresas no financieras ascendía a un 190\% del PIB y la de instituciones financieras era de $127 \%$ del PIB. Y la deuda privada externa consolidada era de $84 \%$ del PIB. 
España entró en recesión en 2009, descendiendo el PIB en un $-3.7 \%$ al mismo tiempo que los precios cayeron en $-0.2 \%$. Esa recesión económica, provocada por el programa de consolidación fiscal y la incertidumbre generada por la crisis bancaria, llevó la tasa de desempleo de $8.3 \%$ en 2008 a un $18 \%$ en 2009 . A partir de ese momento el desempleo ha mantenido una tendencia ascendente, alcanzando un $27 \%$ en 2013. La caída del empleo y de la demanda agregada provocó que el déficit de la cuenta corriente de la balanza de pagos pasara de un déficit de un 10\% en 2007 a un déficit de $4.8 \%$ en 2009 y, posteriormente, a un superávit de un 1.1\% del PIB en 2013.

La crisis económica -en especial el aumento de la tasa de desempleodeterioró las condiciones de vida de la población española. Se estima que la tasa de riesgo de pobreza ${ }^{38}$ aumentó de $19.6 \%$ en 2008 hasta un $21.8 \%$ en $2011 .{ }^{39} \mathrm{El}$ ascenso de la pobreza fue mayor entre los hombres, producto de la caída del sector de la construcción. Murcia, las islas Balearas y Canarias fueron las Comunidades Autónomas con mayores incrementos relativos de la pobreza.

El impacto sobre su población inmigrante fue también significativo. Entre 2007 y 2011 el saldo anual de los flujos migratorios se redujo desde 700 mil a 100 mil por año, explicado por la caída de la inmigración y el aumento de las salidas de España. ${ }^{40}$ Entre 2008 y 2011 se perdieron 2.2 millones de empleos, de los cuales el 15\% corresponde a inmigrantes de América Latina. La tasa de desempleo de la población inmigrante ascendió en 2011 a un 39.1\%, mientras

38 La tasa de riesgo de pobreza mide el porcentaje de la población con una renta por debajo del umbral de pobreza, que se define como el $60 \%$ de la renta mediana equivalente.

39 En European Anti Poverty Network (2012) se presenta la tasa de riesgo de pobreza y exclusión social (AROPE) para España y se señala que pasó de 23.1\% en 2008 a un $26.7 \%$ en 2011.

40 Véase Colectivo Ioé (2012). 
que la de los nacidos en España se situaba en un 18.4\%. La tasa de desocupación de los latinoamericanos era de $28.5 \%$ y la de los jóvenes latinoamericanos se colocó en un $46 \%$, lo cual revela lo difícil para una persona sin experiencia conseguir un primer empleo.

El estudio del Colectivo Ioé (2012) sostiene que durante los años de la crisis se produjo una destrucción generalizada de empleo, mucho mayor para los inmigrantes no comunitarios. La pérdida de empleo fue mayor entre los hombres nacidos en España, latinoamericanos y africanos. Hacia 2011, la tasa de desocupación masculina (32.9\%) superó la femenina (30.1\%). El mayor volumen de empleos temporales perdidos por los inmigrantes correspondió a los nacidos en América Latina. La crisis provocó un aumento de la proporción de empleo indefinido de baja calidad, con jornadas e ingresos limitados. Las actividades de construcción y manufactura fueron las que sufrieron mayor caída del empleo tanto de los nacidos en España como en el extranjero. La tasa de cobertura de las prestaciones de desempleo se ha reducido para los inmigrantes. En 2011 solo el 28\% de los desempleados inmigrantes recibió prestaciones de desempleo en contraste con el 68\% de los españoles. El salario promedio -en términos reales- de los inmigrantes se redujo entre 2006 y 2010 en un $-10.6 \%$, mientras que el de los autóctonos se incrementó en un $0.8 \%$. La caída fue mayor entre los hombres inmigrantes (-14\%). El descenso de los ingresos de los inmigrantes se tradujo en menores remesas para sus familiares. La tasa de pobreza de los hogares de inmigrantes en 2011 se colocó en un 31\% mientras que la incidencia de pobreza en la población autóctona menor a 65 años era de $19 \%$. 


\section{El caso de los dominicanos en Estados Unidos y España}

\subsection{Descripción de la migración dominicana}

El fenómeno de la emigración dominicana se inicia a principios de los años sesenta, aunque se acelera a partir de los noventa. Desde ese entonces se crea una figura que es el dominicano residente en el exterior, que decidió emigrar a una edad muy joven, siendo la mujer la que usualmente toma la decisión a menor edad. El emigrante dominicano procede principalmente de las áreas urbanas, no se encuentra entre los más pobres del país y no es el menos calificado. ${ }^{41}$

Los flujos migratorios desde la República Dominicana se dirigen preponderantemente hacia los Estados Unidos -incluyendo a Puerto Rico- y España. Por un lado, la proximidad geográfica de los Estados Unidos y, por el otro, el mismo idioma y una antigua relación colonial con España son factores determinantes de la selección que realizan aquellos que deciden emigrar desde la República Dominicana hacia el exterior.

En el censo del año 2000 había en los Estados Unidos 799,768 dominicanos $(0.3 \%$ de la población total y $2.3 \%$ de la población hispánica), concentrados principalmente en la ciudad de Nueva York. ${ }^{42}$ Se estima que en el 2006 esa población superó los 1.21 millones de personas ${ }^{43}$, en el 2008 se estimaba en 1.3 millones de personas y en 2010 se alcanzó una cifra de 1.5 millones, de los cuales el 57\% nació en la República Dominicana. ${ }^{44}$ La mayoría de

\footnotetext{
41 Véase Aristy-Escuder (2008).

42 En 2010, el 48\% de los dominicanos en los Estados Unidos vivía en Nueva York y $13.6 \%$ residía en New Jersey.

43 US Census Bureau (2006)

44 Pew Hispanic Center (2012: pp. 1-2.)
} 
los dominicanos llegó a los Estados Unidos a partir de 1990. El 42.6\% llegó a los Estados Unidos entre 1990 y 2000. Solamente un 10.4\% llegó antes de 1970.

En el caso de España la inmigración dominicana se incrementa significativamente en la última década del siglo pasado. A partir de 1990 comenzó a registrarse un aumento sistemático de la población dominicana, principalmente de mujeres, admitidas a trabajar en territorio español. El mismo idioma y la tendencia del gobierno español de otorgar visas de trabajo a personas que se dedicarían a los servicios estimularon la emigración dominicana hacia ese país. Se estima que la población dominicana en el año 2004 era de 65,777 personas, concentrándose el $70.7 \%$ en Madrid y en Barcelona. ${ }^{45}$ Hacia el año 2010 se tenía empadronados a 135,734 dominicanos.

La mujer predomina dentro del conjunto de emigrantes dominicanos residentes en los Estados Unidos, al representar un 54.7\% del total de la población emigrante. Un patrón más acentuado se registra en España donde la mujer representa el 61.6\% del total de la población dominicana residente en ese país. Esa elevada participación de la mujer se debe a que España tiende a otorgar una mayor cantidad de permisos de trabajo a mujeres que a hombres.

La fuerza laboral dominicana se concentra en ocupaciones que reflejan un nivel educativo bajo. En el censo de los Estados Unidos del 2000 se reporta que el $26.4 \%$ está ocupado en servicios, el $25.8 \%$ en producción y transporte, y solo el $15.3 \%$ tiene ocupaciones gerenciales, profesionales y técnicas. Las actividades de servicios educativos y de salud, las industrias manufactureras y el comercio minorista absorben la mayor parte de la mano de obra dominicana en los Estados Unidos. La fuerza laboral de los emigrantes dominicanos residentes en España se concentra en empleos domésticos, restaurantes, hostelería, vendedores y la construcción.

45 Véase Báez-Evertsz (2001) citado en Aristy-Escuder (2008). 
En los Estados Unidos, en el año 2008, la mediana del ingreso personal de los dominicanos con 16 años o más era de 20,571 dólares y hacia 2010 ese ingreso había caído a 20,000 dólares. Al inicio de la crisis financiera, el $23.2 \%$ de los dominicanos era pobre, mientras que en 2010 había subido a 26\%. En el año 2008, el $28.3 \%$ de los dominicanos tenía una residencia propia y hacia el año 2010 ese porcentaje se había reducido a un $24 \% .46$

\subsection{Principales hipótesis de la Gran Recesión y la migración dominicana}

1. La crisis económica redujo las posibilidades de obtener un empleo e hizo que incrementase la percepción de perder el empleo entre los emigrantes dominicanos.

2. La crisis económica provocó movimientos de la mano de obra dominicana entre distintas actividades productivas.

3. La crisis económica deterioró la calidad del empleo (e. g., disminuyó la cantidad de horas trabajadas y redujo el ingreso por hora trabajada) del dominicano emigrante.

4. En 2011 el ingreso promedio de los dominicanos en términos reales fue inferior al ingreso recibido en 2008.

5. El mercado laboral de Estados Unidos es más flexible al llevar a cabo ajustes salariales hacia la baja para conservar empleo.

6. La crisis inmobiliaria no destruyó significativamente la riqueza de los dominicanos emigrantes.

7. La crisis económica provocó cambios en el patrón de consumo e inversión de los dominicanos. Se redujo el consumo de bienes no perecederos y/o se pospusieron inversiones de una magnitud considerable debido a la crisis económica.

46 Pew Hispanic Center (2012, 2010).

498 Ciencia y Sociedad 2015; 40(3): 477-563 
8. A pesar de la crisis económica, los dominicanos residentes en el exterior no desean retornar al territorio dominicano, pues los flujos migratorios se correlacionan más con las condiciones económicas del país de origen (República Dominicana) y menos con las del país receptor.

9. La crisis económica provocará que los flujos migratorios de los dominicanos hacia el exterior (Estados Unidos, Puerto Rico y España) se detengan o disminuyan su ritmo de crecimiento.

10. Los dominicanos reducirán la cantidad de remesas que envían hacia sus familiares en la República Dominicana debido al aumento de la tasa de desempleo y la disminución de sus ingresos.

11. El volumen agregado de las remesas depende del ciclo económico de los Estados Unidos y de España.

\subsection{Modelos econométricos}

Con el objetivo de evaluar las hipótesis de manera rigurosa, en las siguientes secciones se estiman modelos econométricos que cuantifican el impacto de las variables explicativas.

Se presentan varios modelos econométricos que analizan la influencia de los determinantes del estado laboral (i.e., si está o no empleado y la cantidad de horas trabajadas) de los individuos entrevistados en función de sus características sociodemográficas y del país receptor.

Además, se estiman modelos que cuantifican la reacción, medida por cambios en el patrón de consumo, de los dominicanos emigrantes ante las modificaciones de sus condiciones laborales.

Se estima la ecuación de Mincer para determinar el retorno de la educación y la discriminación de género en el mercado laboral de los países receptores para el caso de los migrantes dominicanos. 
Se estima también un modelo de determinantes de remesas en función de las características sociodemográficas y del mercado laboral (e. g., si está o no empleado). En términos macroeconómicos se estima un modelo que hace depender las remesas de la desviación del PIB actual del PIB potencial tanto de los Estados Unidos como de España, con lo cual se cuantifica la relación de las remesas y el ciclo económico de los países receptores de inmigrantes.

\subsection{Principales resultados de la encuesta}

Los siguientes resultados se fundamentan en una encuesta aplicada a dominicanos residentes en los Estados Unidos, en España y en Puerto Rico para determinar el impacto de la crisis económica sobre su acceso a un puesto de trabajo y, en consecuencia, sobre su nivel de ingresos laboral. Se aplicaron 381 cuestionarios: 178 en las ciudades de Nueva York y New Jersey; 126 en la ciudad española de Madrid; y 77 en San Juan de Puerto Rico. La información de esa encuesta permitió un análisis descriptivo de las variables relacionadas con la crisis y el bienestar de los dominicanos. Esos datos también se usaron para la estimación de modelos econométricos que permiten determinar el impacto de la Gran Recesión de los Estados Unidos y de España en los ingresos de los dominicanos y, por lo tanto, en su capacidad de envío de remesas hacia la República Dominicana.

\subsubsection{Características sociodemográficas}

La distribución por país de las encuestas realizadas se muestra en el siguiente gráfico. El 46.7\% de los encuestados son emigrantes dominicanos que residen en Estados Unidos, el 33.1\% en España y el restante $20.2 \%$ en Puerto Rico. Los emigrantes dominicanos tienen, en promedio, 12 años residiendo en su país de destino. En promedio, en los Estados Unidos los entrevistados indicaron estar residiendo desde hace 14 años, en Puerto Rico 17 años y en España 6 años. 
Gráfico N. ${ }^{\circ} 2$

Proporción de entrevistados según país de residencia

(cifras en \%)

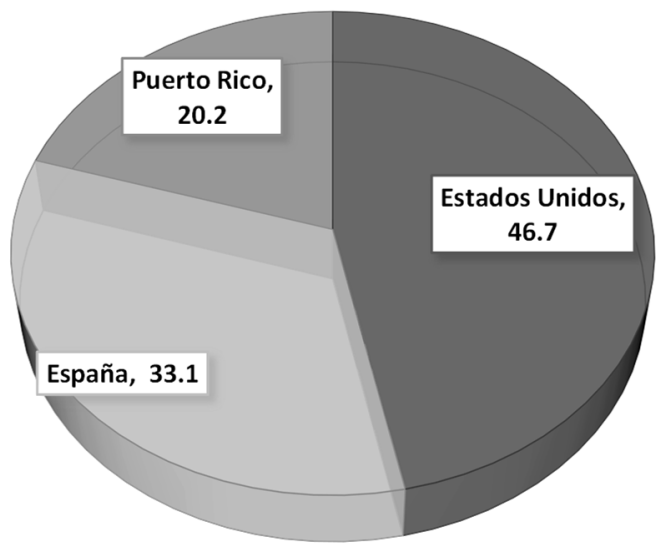

En términos de género, el 50.4\% de los entrevistados son mujeres y el restante $49.6 \%$ son hombres. La población cubierta es relativamente joven. La mediana de la edad de los encuestados es 36 años, con un mínimo de 16 años y máximo de 78 años.

\section{Gráfico N. ${ }^{\circ} 3$}

Distribución edad de los emigrantes entrevistados

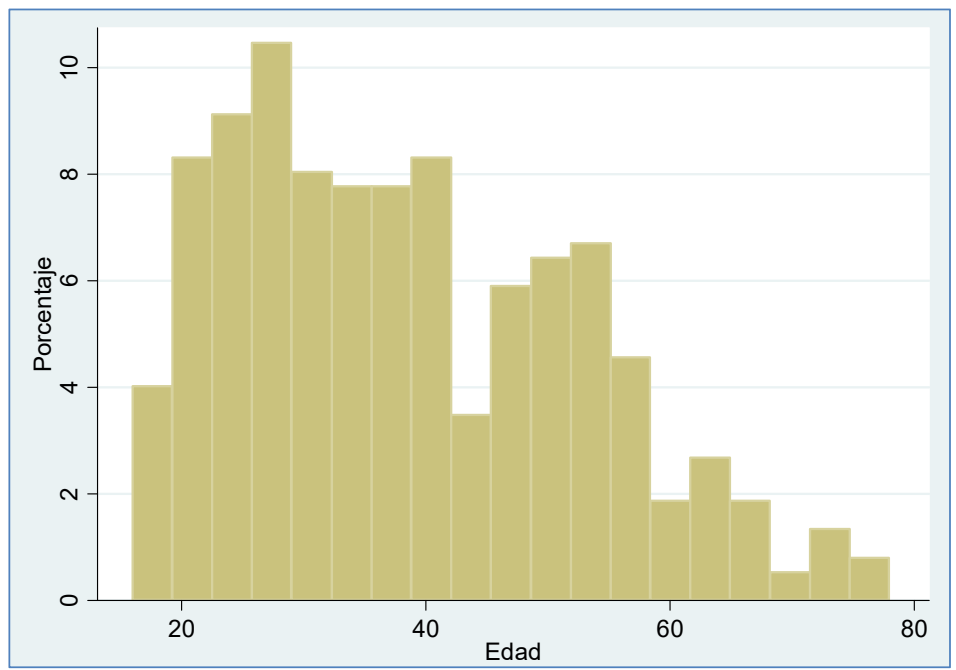


En cuanto al nivel de educación, la mayoría de los entrevistados cuenta con algún nivel de educación (96.1\%). Sin embargo, el $53.5 \%$ no posee educación universitaria, es decir, para este grupo de personas el máximo nivel de educación alcanzado es el nivel secundario.

\section{Gráfico N. ${ }^{\circ} 4$ \\ Nivel de educación \\ (cifras en \%)}

Postgrado/maestría/doctorado

Terminó educación universitaria

Educación universitaria

Técnico-vocacional

Terminó educación secundaria

Educación secundaria

Terminó educación primaria

Educación primaria

Sin educación forma

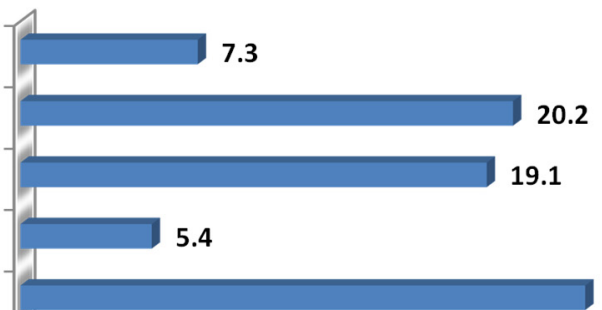

23.1

15.3

5.6

2.4

1.6

$\begin{array}{lllll}5.0 & 10.0 & 15.0 & 20.0 & 25.0\end{array}$

El 84\% de los entrevistados declaró tener tres hijos o menos (31.3\% no tiene) y el restante $16 \%$ más de tres. De aquellos que declararon tener hijos, el $71.7 \%$ confirma que estos tienen más de 5 años de edad. Sin embargo, existe una alta dependencia de hijos sobre el ingreso de sus padres. El 75.5\% de quienes tienen hijos indicaron que estos dependen de su nivel de ingreso.

El estado conyugal que predomina en la población emigrante entrevistada es soltero(a) (41.5\%). Al incluir las personas divorciadas o separadas y quienes están en condición de viudez, el 55.6\% se encuentra sin una pareja. El restante $44.4 \%$ está casado y/o unido. 


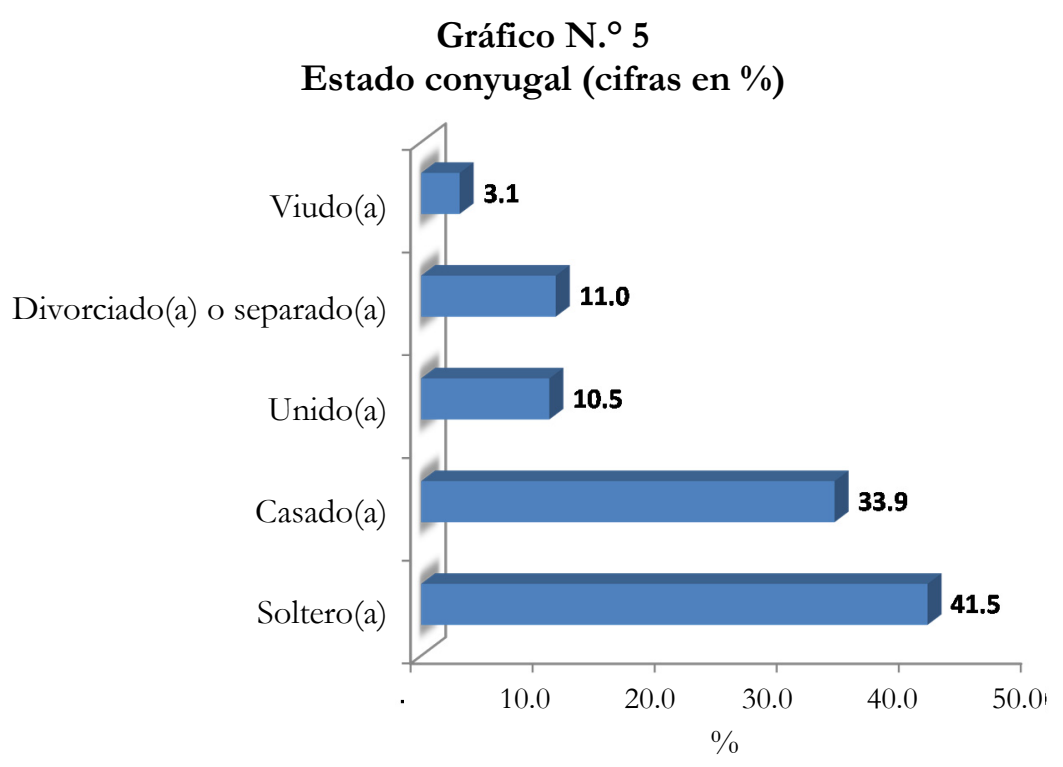

El ingreso promedio mensual percibido en el 2011 por la población entrevistada es de 2,011 dólares y con una mediana de 1,431 dólares. Los mayores ingresos promedio los generan los residentes en Estados Unidos con 2,485 dólares, seguido por Puerto Rico con 1,805 dólares y finalmente España con 1,397 dólares.

\section{Gráfico N. ${ }^{\circ} 6$}

Ingreso promedio mensual por país de residencia

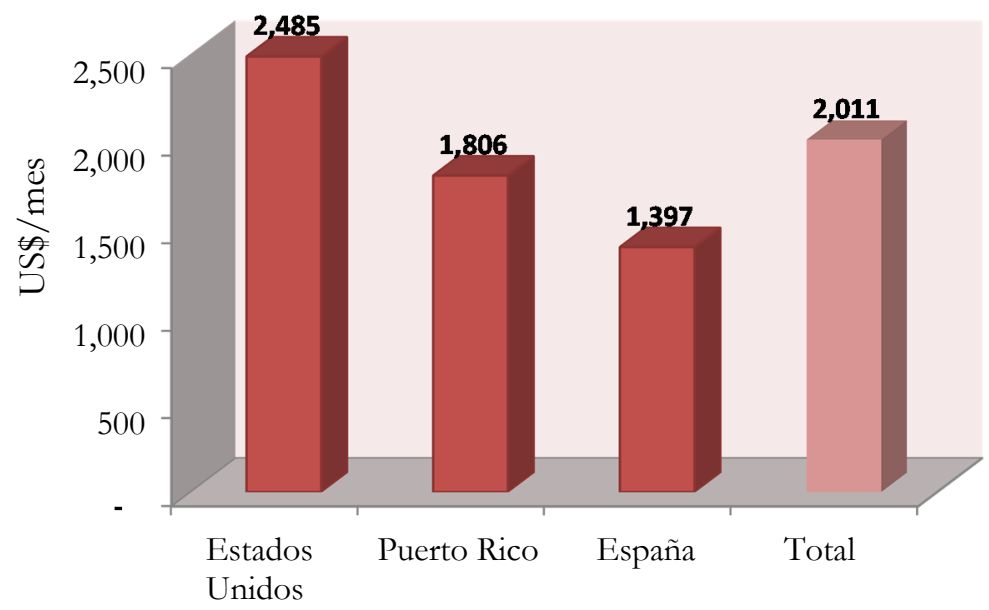


El hombre es quien mayor ingreso mensual genera con 2,372 dólares frente a la mujer con 1,636 dólares. En cuanto al ingreso medio en función de la edad, se observa una tendencia creciente en la medida que transcurren los años hasta alcanzar la edad promedio de 47 años, momento a partir del cual se genera un punto de inflexión y comienza a descender.

\section{Gráfico N. ${ }^{\circ} 7$}

Ingreso promedio según edad media de grupos etarios ${ }^{47}$

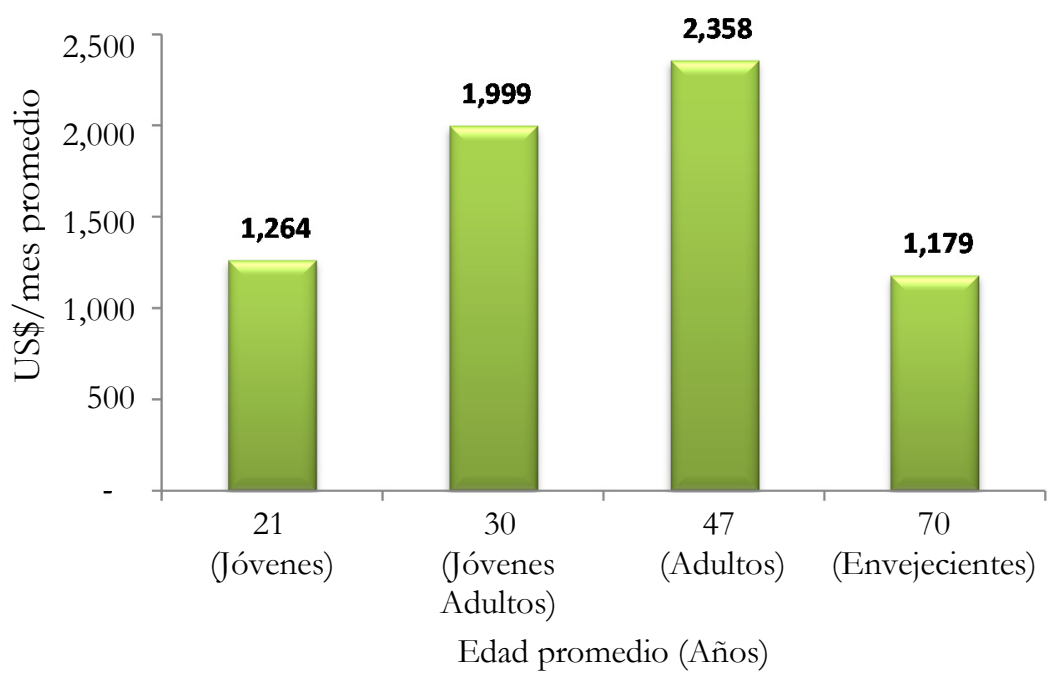

En cuanto a los sectores económicos dentro de los cuales se encuentran laborando los emigrantes dominicanos, los resultados de la encuesta reflejan que la mayoría trabaja en el sector servicios (79.8\%), seguido por comercio (18.2\%) y finalmente manufactura $(2 \%)$. El promedio de ingresos para quienes trabajan en actividades de servicios es de 2,359 dólares y para aquellos que laboran en comercio es de 2,143 dólares.

47 Definición de grupos etarios: Jóvenes (15 a 24 años), Jóvenes adultos (25 a 34 años), Adultos (35 a 64 años), Envejecientes (más de 64 años).

504 Ciencia y Sociedad 2015; 40(3): 477-563 
En la encuesta se preguntó sobre algunas características de la pareja del entrevistado. Específicamente se cuestionó sobre la situación laboral, nivel de ingreso y el nivel educativo. La mayoría de las parejas se encontraba trabajando en el $2011(66.5 \%)$, con un ingreso promedio mensual de 2,629 dólares y una mediana de 1,800 dólares. $\mathrm{Al}$ descomponer por el género de la pareja, se tiene como resultado que el hombre tiene un ingreso promedio de 3,301 dólares y un porcentaje de estar empleado de $77.9 \%$. La mujer tiene un ingreso promedio de 1,970 dólares y un porcentaje de estar trabajando de un 58.6\%. La crisis económica redujo las oportunidades de empleo para las parejas, al pasar el porcentaje empleado ${ }^{48}$ de $74.8 \%$ en 2008 a 66.5\% en 2011. Aquellas parejas que no se encontraban trabajando en 2011 indicaron no estarlo por razones personales (40.7\%). El 29.6\% declaró que nunca ha trabajado y el 7.4\% de las parejas que no estaba trabajando indicó que perdió el empleo. En cuanto a nivel de educación, el $50.9 \%$ de las parejas posee educación secundaria o menos. La pareja masculina tiene en promedio mayor nivel de educación. El $42.4 \%$ de los hombres tiene un nivel de educación igual o inferior a secundaria, en contraste con el $56.6 \%$ de las mujeres.

\subsubsection{Situación laboral}

En la encuesta realizada se evalúa la situación laboral acotada tanto a la población económicamente activa (PEA) así como de la población total entrevistada. La PEA, de acuerdo a la Organización Internacional de Trabajo (OIT), se define como "todas aquellas personas que durante el período de referencia especificado pueden clasificarse como personas con empleo o como personas

48 El 29.6\% de las parejas no estaba viviendo en el territorio receptor en 2008. El porcentaje de empleado o no empleado en el 2008 se realiza tomando en consideración únicamente a las parejas que estaban residiendo en ese año en el país receptor. 
desempleadas, es decir, que aportan al trabajo."49 En el contexto de la entrevista realizada, se trata de la cantidad total de personas que se encuentran en una de las siguientes condiciones:

- Trabajando.

- Trabajando y buscando trabajo.

- No trabaja y busca trabajo.

Aquellas personas que no trabajan y que simultáneamente no están buscando trabajo, así como las pensionadas, no se consideran parte de la PEA.

\section{Gráfico $\mathbf{N}^{\circ} 8$}

Situación laboral (cifras en \%)

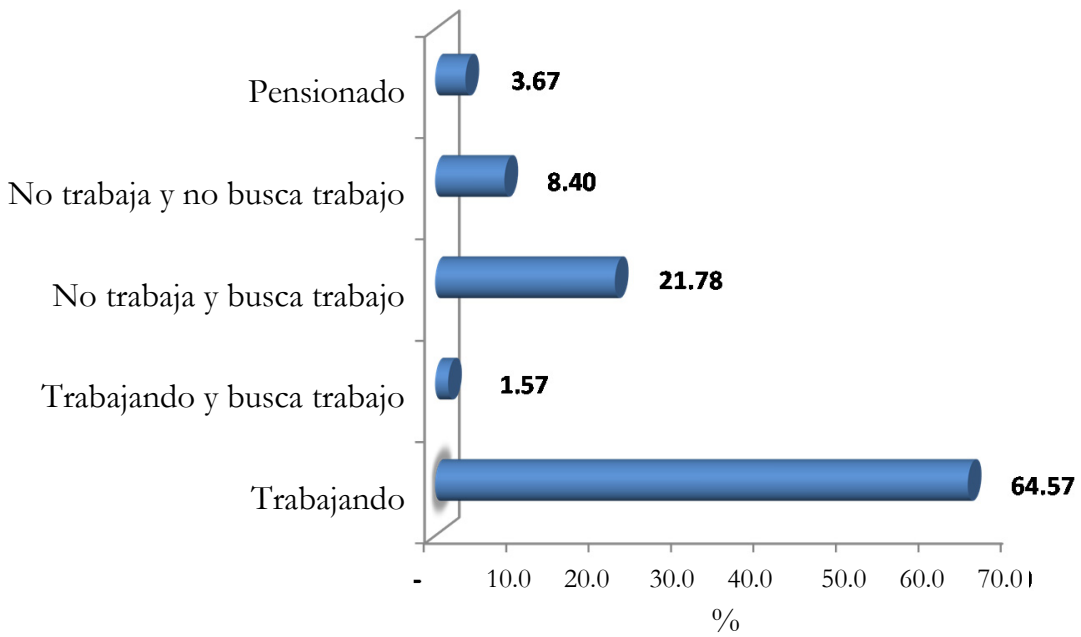

En el año 2011, el 87.9\% de los dominicanos encuestados era parte de la PEA. Esta última se compone principalmente de adultos ${ }^{50}$ $(50.5 \%)$ y hombres $(52.8 \%)$. Como se observa en el gráfico N. ${ }^{\circ}$,

49 Véase http://laborsta.ilo.org/applv8/data/c1s.html. Para definición de persona desempleada, véase http://laborsta.ilo.org/applv8/data/c3s.html. Para la definición de persona con empleo, véase http://laborsta.ilo.org/applv8/data/c2s.html.

${ }^{50}$ Este grupo tiene una edad de 35 a 64 años.

506 Ciencia y Sociedad 2015; 40(3): 477-563 
existe una alta proporción de la PEA que no trabaja pero busca trabajo, que, junto a una duración media de desempleo de 15 meses, es indicativo de un mercado laboral difícil para el emigrante en términos de oportunidades de empleo.

La tasa de desempleo ${ }^{51}$ en 2011 para los dominicanos en el exterior ascendió a un 24.8\%. Al descomponer por grupos etarios, la población joven (menor o igual a 34 años) es la más afectada, con una tasa de desempleo $35.1 \%$. En cuanto al género, se observa una concentración en las mujeres con una tasa de $30.4 \%$ mientras que para los hombres se registró una cifra de 19.8\%. En términos de países, los dominicanos en España reflejan la tasa de desempleo más alta con $44.4 \%$, seguido por Estados Unidos con $16.6 \%$ y, finalmente, Puerto Rico con $9.6 \%$. En cuanto al desempleo según nivel de calificación, los resultados muestran una mayor tasa de desempleo entre los calificados con $26 \%$ frente a los no calificados con $23.3 \%$.

La tasa de empleo -medida como el empleo como porcentaje de la población total- es de $66.1 \%$. En los Estados Unidos, esa tasa asciende a 68\%, en España a 51.6\% y en Puerto Rico a 85.7\%. La mujer tiene una menor presencia en el mercado laboral. De cada 100 mujeres - pertenecientes o no a la PEA- solo 57 están trabajando, mientras que 75 hombres lo están haciendo. Por país se observa, que Puerto Rico es el mercado en que mayor presencia en el empleo tiene la mujer. El $84.4 \%$ del total de mujeres afirma que está trabajando, cifra muy parecida al $86.7 \%$ del total de hombres. En el caso de España de cada 100 mujeres solo 50 contestaron que están trabajando. Los hombres no están muy distantes, pues solo un 53.7\% afirmó tener un empleo. En los Estados Unidos el comportamiento es diferente, pues se observa una separación notable entre la mujer y el hombre. Mientras el $82.2 \%$ de los hombres está trabajando, solo el $53.4 \%$ de las mujeres trabaja.

51 (No trabaja y busca trabajo)/PEA: corresponde a la definición de desocupación abierta del Banco Central de la República Dominicana (Recuperado de http://www.bancentral. gov.do/ayuda.asp?a=D) 
Tabla N. ${ }^{\circ} 1$

Empleados en 2011 según sexo y país receptor

(Como porcentaje de la población total)

\begin{tabular}{|c|c|c|c|c|c|c|c|c|c|}
\hline \multirow{2}{*}{\multicolumn{2}{|c|}{ Total }} & \multicolumn{2}{|c|}{ Mujer } & \multirow{4}{*}{$\begin{array}{c}\text { Total } \\
33.9\end{array}$} & \multirow{2}{*}{\multicolumn{2}{|c|}{ EE.UU. }} & \multicolumn{2}{|c|}{ Mujer } & \multirow{3}{*}{$\begin{array}{c}\text { Total } \\
32.0\end{array}$} \\
\hline & & \multirow{2}{*}{$\begin{array}{l}\text { No } \\
24.9\end{array}$} & \multirow{2}{*}{$\begin{array}{c}\mathbf{S i} \\
42.7\end{array}$} & & & & No & $\mathbf{S i}$ & \\
\hline \multirow{2}{*}{ 疍 } & No & & & & \multirow{2}{*}{ 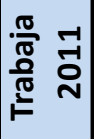 } & No & 17.8 & 46.6 & \\
\hline & Si & 75.1 & 57.3 & & & Si & 82.2 & 53.4 & 68.0 \\
\hline \multicolumn{2}{|r|}{ Total } & 100.0 & 100.0 & 100.0 & & Total & 100.0 & 100.0 & 100.0 \\
\hline \multicolumn{2}{|c|}{ España } & \multicolumn{2}{|c|}{ Mujer } & & \multirow{2}{*}{\multicolumn{2}{|c|}{ Puerto Rico }} & \multicolumn{2}{|c|}{ Mujer } & \\
\hline & & No & Si & Total & & & No & Si & Total \\
\hline \multirow{2}{*}{ 疍 } & No & 46.3 & 50.0 & 48.4 & \multirow{2}{*}{ 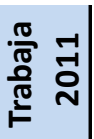 } & No & 13.3 & 15.6 & 14.3 \\
\hline & Si & 53.7 & 50.0 & 51.6 & & $\mathbf{S i}$ & 86.7 & 84.4 & 85.7 \\
\hline & Total & 100.0 & 100.0 & 100.0 & & Total & 100.0 & 100.0 & 100.0 \\
\hline
\end{tabular}

Las personas sin empleo no poseen una pareja que, en promedio, tenga una mayor probabilidad de estar trabajando. De acuerdo con los datos obtenidos de la encuesta el 66.7\% de los que sí trabajan tiene una pareja que está trabajando, mientras que el 66\% de los que no trabajan tiene una pareja que sí está trabajando. Sin embargo, al descomponer por países se observan algunas diferencias. En España y Puerto Rico, los segmentos de población sin empleo tienen una mayor probabilidad de tener una pareja trabajando $(66.7 \%$ y 75\%, respectivamente), con relación a la población que está empleada (60.7\% y 66.7\%, respectivamente). En los Estados Unidos, las personas sin empleo tienen una probabilidad de tener una pareja trabajando de un $62.5 \%$, mientras que aquellos que están trabajando tienen una probabilidad de $69.2 \%$. 
Tabla N. ${ }^{\circ} 2$

Situación laboral de la pareja (cifras en \%)

\begin{tabular}{|c|c|c|c|c|}
\hline \multirow[t]{2}{*}{ Total } & & \multicolumn{2}{|c|}{ Trabaja su pareja } & \multirow[b]{2}{*}{ Total } \\
\hline & & No & Si & \\
\hline \multirow{2}{*}{ 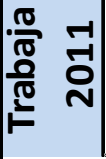 } & No & 34.0 & 66.0 & 100.0 \\
\hline & Si & 33.3 & 66.7 & 100.0 \\
\hline & Total & 33.5 & 66.5 & 100.0 \\
\hline
\end{tabular}

La edad tiene una influencia determinante sobre la probabilidad de estar empleado. En los Estados Unidos, los empleados tienen una edad promedio de casi 40 años, mientras que las personas sin empleo tienen 37 años. En España, los que trabajan tienen en promedio 37 años y los que no trabajan tienen una edad promedio de 34 años. En el caso de Puerto Rico, los que no trabajan tienen una edad promedio de 50 años y los que tienen empleo son en promedio 7 años más jóvenes. Esto sugiere que existe una relación no lineal entre la edad y la probabilidad de estar empleado.

Tabla N..$^{\circ} 3$

Edad, cantidad de hijos y años de residencia (cifras en \%)

Valores Promedio Con Empleo

\begin{tabular}{|lrrrr|}
\multicolumn{1}{c}{ Variable } & EE.UU. & España & Puerto Rico & \multicolumn{1}{c|}{ Total } \\
\hline Edad & 39.51 & 36.56 & 43.23 & 39.75 \\
\hline Cantidad de hijos & 1.63 & 1.42 & 2.97 & 1.92 \\
\hline Años de residencia & 15.69 & 6.85 & 17.28 & 13.78 \\
\hline
\end{tabular}

Valores Promedio Sin Empleo

\begin{tabular}{|lrrrr|}
\multicolumn{1}{c}{ Variable } & EE.UU. & España & Puerto Rico & \multicolumn{1}{c|}{ Total } \\
\hline Edad & 36.88 & 33.62 & 49.55 & 36.43 \\
\hline Cantidad de hijos & 1.23 & 1.50 & 3.55 & 1.55 \\
\hline Años de residencia & 12.33 & 5.89 & 20.73 & 10.00 \\
\hline
\end{tabular}


El tiempo residiendo en el país parece influir sobre la probabilidad de trabajar, pero condicionado por el territorio de residencia. Aquellas personas que están trabajando tienen casi 14 años residiendo en el extranjero, mientras que los que no trabajan tienen 10 años. De forma compatible con la evolución de los flujos migratorios se observa que los dominicanos que residen en Puerto Rico son los que tienen mayor tiempo en el extranjero. En ese territorio los que no trabajan tienen 20 años residiendo allí, mientras los que poseen empleo tienen 17 años. En contraste, los que viven y trabajan en los Estados Unidos tienen 16 años de residencia y los que no trabajan tienen 12 años. En España se registra un patrón que refleja que los flujos migratorios son más recientes. En efecto, los que trabajan tienen 7 años residiendo y los que no trabajan 6 años.

Los dominicanos residentes en el extranjero con menor nivel de calificación poseen una ligera ventaja en la probabilidad de estar empleados. Si se clasifica a las personas con educación secundaria o menos como "no calificados" y a los que poseen educación universitaria o postgrado como "calificados" se registra que alrededor del $68 \%$ de los no calificados tiene empleo, mientras que solo el $64 \%$ de los calificados lo tiene.

Al descomponer por país se tiene que en los Estados Unidos los no calificados tienen una probabilidad de un $71.4 \%$ de estar empleados, mientras que para los calificados se reduce a un 65.4\%. En España se repite un patrón similar: la probabilidad de emplearse para los no calificados es de un $53.9 \%$ y la de los calificados es de un 47.6\%. En el caso de Puerto Rico la situación es diferente. Los calificados tienen una probabilidad de un $87.5 \%$ de estar empleados, mientras que la probabilidad de los no calificados es de un $84.3 \%$. 
Tabla N. ${ }^{\circ} 4$

Situación laboral según nivel de calificación (cifras en \%)

\begin{tabular}{|c|c|c|c|c|c|c|c|c|c|}
\hline \multicolumn{2}{|c|}{ EE.UU. } & \multicolumn{2}{|c|}{ Trabaja 2011} & \multirow{3}{*}{$\begin{array}{l}\text { Total } \\
100.0\end{array}$} & \multicolumn{2}{|c|}{ España } & \multicolumn{2}{|c|}{ Trabaja 2011} & \multirow{2}{*}{ Total } \\
\hline & & No & $\mathbf{S i}$ & & & & No & Si & \\
\hline \multirow{3}{*}{ 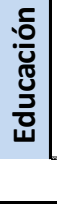 } & No calificado & 28.6 & 71.4 & & |은 & No calificado & 46.2 & 53.8 & 100.0 \\
\hline & Calificado & 34.6 & 65.4 & 100.0 & 훔 & Calificado & 52.4 & 47.6 & 100.0 \\
\hline & Total & 32.2 & 67.8 & 100.0 & & Total & 48.3 & 51.7 & 100.0 \\
\hline \multicolumn{2}{|c|}{ Puerto Rico } & \multicolumn{2}{|c|}{ Trabaja 2011} & & \multirow{2}{*}{\multicolumn{2}{|c|}{ Total }} & \multicolumn{2}{|c|}{ Trabaja 2011} & \\
\hline & & No & $\mathrm{Si}$ & Total & & & No & Si & Total \\
\hline \multirow{3}{*}{ 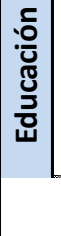 } & No calificado & 15.7 & 84.3 & 100.0 & 은 & No calificado & 32.2 & 67.8 & 100.0 \\
\hline & Calificado & 12.5 & 87.5 & 100.0 & 름 & Calificado & 35.8 & 64.2 & 100.0 \\
\hline & Total & 14.7 & 85.3 & 100.0 & & Total & 33.9 & 66.1 & 100.0 \\
\hline
\end{tabular}

\section{MODELO ECONOMÉTRICO DE PROBABILIDAD DE ESTAR EMPLEADO}

En la siguiente tabla se presentan los resultados de cinco modelos probit estimados que cuantifican los principales determinantes de la probabilidad de estar empleado. Los resultados muestran que esa probabilidad depende de manera cuadrática de la edad: la probabilidad de estar empleado se eleva con la edad hasta cierto punto y posteriormente comienza a descender. Todos los modelos revelan consistentemente que ser mujer reduce la probabilidad de estar empleado. A mayor tiempo de residencia más alta es la probabilidad de estar empleado. La variable educación, que tiene las categorías sin educación formal, primaria, secundaria, universitaria y postgrado, revela que los que tienen mayor probabilidad de estar empleados son los que poseen menor educación. Sin embargo, esa conclusión no es del todo robusta porque la variable educación construida como persona calificada (que posee educación universitaria o de postgrado) y no calificada (sin educación formal, primaria y secundaria) no tiene una influencia estadísticamente significativa sobre la probabilidad de estar empleado. El estado civil (soltero o casado) 
ni la cantidad de hijos tienen influencia estadísticamente significativa sobre la probabilidad de estar empleado. Por último, la variable que recoge el territorio (estrato 2) revela que no existe diferencia estadística entre los Estados Unidos y Puerto Rico, pero sí entre esos dos países y España. Específicamente, se observa que estar en territorio español reduce significativamente la probabilidad de estar empleado.

Tabla N. ${ }^{\circ} 5$

Modelo de empleo

\begin{tabular}{|c|c|c|c|c|c|}
\hline & $\begin{array}{r}(1) \\
\text { modelo1 }\end{array}$ & $\begin{array}{r}(2) \\
\text { modelo2 }\end{array}$ & $\begin{array}{r}(3) \\
\text { modelo3 }\end{array}$ & $\begin{array}{r}(4) \\
\text { mode104 }\end{array}$ & $\begin{array}{r}(5) \\
\text { modelo5 }\end{array}$ \\
\hline edad & $\begin{array}{l}0.1624 \\
(5.72) * * *\end{array}$ & $\begin{array}{l}0.1697 \\
(5.75)^{* * *}\end{array}$ & $\begin{array}{l}0.1752 \\
(5.72) * * *\end{array}$ & $\begin{array}{l}0.1885 \\
(6.24) * * *\end{array}$ & $\begin{array}{l}0.1624 \\
(5.62) * * *\end{array}$ \\
\hline edad2 & $\begin{array}{l}-0.0020 \\
(-5.85)^{* * *}\end{array}$ & $\begin{array}{l}-0.0021 \\
(-5.81)^{* * *}\end{array}$ & $\begin{array}{l}-0.0021 \\
(-5.82) * * *\end{array}$ & $\begin{array}{l}-0.0022 \\
(-6.16) * * *\end{array}$ & $\begin{array}{l}-0.0019 \\
(-5.76) * * *\end{array}$ \\
\hline mujer & $\begin{array}{l}-0.5010 \\
(-3.54)^{* * *}\end{array}$ & $\begin{array}{l}-0.5038 \\
(-3.50) * * *\end{array}$ & $\begin{array}{l}-0.5267 \\
(-3.60) * * *\end{array}$ & $\begin{array}{l}-0.4166 \\
(-2.85) * *\end{array}$ & \\
\hline tiempo & $\begin{array}{l}0.0300 \\
(3.35) * * *\end{array}$ & $\begin{array}{l}0.0286 \\
(3.15)^{* *}\end{array}$ & $\begin{array}{l}0.0275 \\
(3.04)^{* *}\end{array}$ & & $\begin{array}{l}0.0264 \\
(2.92) * *\end{array}$ \\
\hline _Ieduc_1 & & $\begin{array}{l}-1.3569 \\
(-2.27)^{*}\end{array}$ & $\begin{array}{l}-1.3254 \\
(-2.22)^{*}\end{array}$ & $\begin{array}{l}-1.2531 \\
(-1.95)\end{array}$ & \\
\hline _Ieduc_2 & & $\begin{array}{l}-1.1060 \\
(-1.95)\end{array}$ & $\begin{array}{l}-1.1435 \\
(-1.99)^{*}\end{array}$ & $\begin{array}{l}-1.0154 \\
(-1.63)\end{array}$ & \\
\hline _Ieduc_3 & & $\begin{array}{l}-1.2011 \\
(-2.09)^{*}\end{array}$ & $\begin{array}{l}-1.2368 \\
(-2.12)^{*}\end{array}$ & $\begin{array}{l}-1.2414 \\
(-1.97)^{*}\end{array}$ & \\
\hline _Ieduc_4 & & $\begin{array}{l}-1.4633 \\
(-2.38)^{*}\end{array}$ & $\begin{array}{l}-1.5176 \\
(-2.40)^{*}\end{array}$ & $\begin{array}{l}-1.3842 \\
(-2.09) *\end{array}$ & \\
\hline soltero & & & $\begin{array}{l}0.0822 \\
(0.52)\end{array}$ & & $\begin{array}{l}0.0228 \\
(0.15)\end{array}$ \\
\hline qhijos & & & $\begin{array}{l}-0.0132 \\
(-0.27)\end{array}$ & & $\begin{array}{l}0.0211 \\
(0.50)\end{array}$ \\
\hline _Iestrato2_2 & & & & $\begin{array}{l}-0.6529 \\
(-3.79) * * *\end{array}$ & \\
\hline _Iestrato2_3 & & & & $\begin{array}{l}0.3825 \\
(1.67)\end{array}$ & \\
\hline _cons & $\begin{array}{l}-2.6330 \\
(-4.70) * * *\end{array}$ & $\begin{array}{l}-1.5519 \\
(-2.14)^{*}\end{array}$ & $\begin{array}{l}-1.6549 \\
(-2.18)^{*}\end{array}$ & $\begin{array}{l}-1.5808 \\
(-2.02)^{*}\end{array}$ & $\begin{array}{l}-2.9191 \\
(-4.88) * * *\end{array}$ \\
\hline $\begin{array}{l}\mathrm{N} \\
\text { pseudo R-sq } \\
\text { AIC } \\
\text { BIC } \\
11\end{array}$ & $\begin{array}{r}370 \\
0.122 \\
427.6897 \\
447.2572 \\
-208.8449\end{array}$ & $\begin{array}{r}362 \\
0.132 \\
422.0780 \\
457.1028 \\
-202.0390\end{array}$ & $\begin{array}{r}360 \\
0.131 \\
422.5193 \\
465.2665 \\
-200.2597\end{array}$ & $\begin{array}{r}365 \\
0.161 \\
412.5719 \\
451.5709 \\
-196.2860\end{array}$ & $\begin{array}{r}368 \\
0.095 \\
438.6133 \\
462.0618 \\
-213.3066\end{array}$ \\
\hline
\end{tabular}

512 Ciencia y Sociedad 2015; 40(3): 477-563 
El modelo de empleo seleccionado para realizar las predicciones de la probabilidad de estar empleado controla por la influencia del país de residencia y por género. De manera que permite determinar la diferencia entre mujer y hombre después de tomar en consideración el efecto del territorio de residencia. Los resultados para mujeres y hombres, jóvenes (25 años) y maduros (50 años), con nivel de educación de secundaria y por país, se presentan en la siguiente tabla.

\section{Tabla N. ${ }^{\circ} 6$}

Predicciones probabilidad de estar empleado con educación secundaria

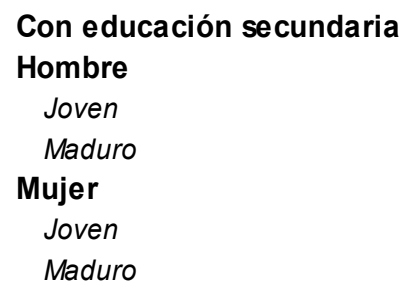

Probabilidad de estar empleado

\begin{tabular}{ccr} 
EE.UU. & España & Puerto Rico \\
\hline $\mathbf{0 . 7 9 1 8}$ & $\mathbf{0 . 6 5 0 8}$ & $\mathbf{0 . 9 1 4 1}$ \\
0.7692 & 0.5333 & 0.8684 \\
0.9049 & 0.7445 & 0.9547 \\
$\mathbf{0 . 6 4 3 3}$ & $\mathbf{0 . 4 7 6 9}$ & $\mathbf{0 . 8 2 1 4}$ \\
0.6254 & 0.3695 & 0.7587 \\
0.8142 & 0.5951 & 0.8990
\end{tabular}

Los resultados revelan que en promedio el hombre (75.13\%) tiene casi 18 más puntos porcentuales que la mujer $(57.29 \%)$ de tener un empleo. Al descomponer por edad se tiene como resultado que, en promedio, el hombre maduro tiene más probabilidad de estar empleado, al igual que la mujer madura. Por último, se ve que la persona que tiene más probabilidad de estar trabajando es el dominicano maduro residente en Puerto Rico (95.5\%) y quien tiene menos probabilidad de estar trabajando es la dominicana joven residente en España (36.95\%). 


\section{CANTIDAD DE HORAS QUE TRABAJA}

\section{Gráfico N. ${ }^{\circ} 9$}

Horas de trabajo a la semana

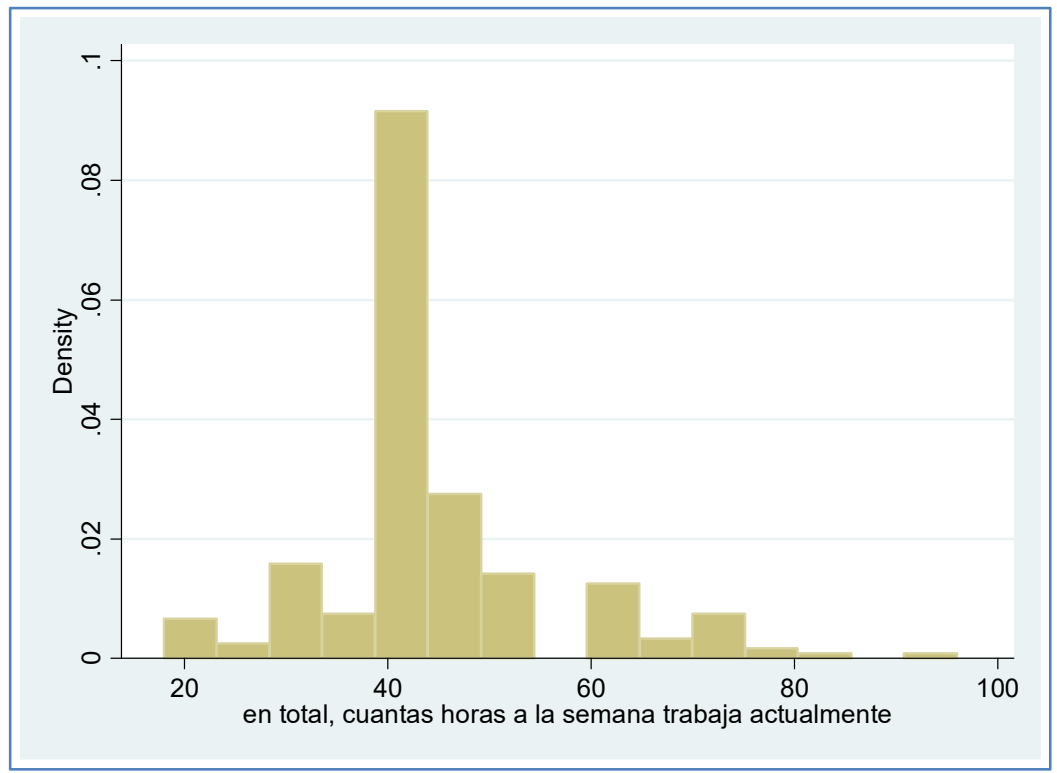

El género y la cantidad de hijos son variables que influyen sobre la cantidad de horas disponibles para trabajar. Se realizó una prueba de igualdad de medias, pero previamente se verificó si existe igualdad de varianzas para poder realizar la prueba de medias. Los resultados [ver anexo 1] arrojaron que la varianza es distinta para ambos grupos, por lo tanto, se llevó a cabo la prueba de medias con varianzas desiguales. El resultado arrojó [ver anexo 2] que se puede rechazar la hipótesis nula de igual media entre mujeres y hombres en las horas trabajadas. La mujer (41.6 horas) trabaja en promedio menos horas a la semana que el hombre (45.3 horas). 
Tabla N. ${ }^{\circ} 7$

Horas de trabajo a la semana según sexo

Horas trabajadas a la semana 2011 - Hombre

\begin{tabular}{cccrcc} 
Variable & Obs & Mean & Std. Dev. & Min & Max \\
\hline Horas/Semana & 129.00 & 45.29 & 12.94 & 18.00 & 96.00 \\
\hline
\end{tabular}

Horas trabajadas a la semana 2011 - Mujer

\begin{tabular}{cccrcl} 
Variable & Obs & Mean & Std. Dev. & Min & Max \\
Horas/Semana & 102.00 & 41.55 & 10.16 & 20.00 & 72.00 \\
\hline
\end{tabular}

Tabla N. ${ }^{\circ} 8$

Modelos de horas trabajadas por semana

\begin{tabular}{|c|c|c|}
\hline & $\begin{array}{r}(1) \\
\text { Mode101 }\end{array}$ & $\begin{array}{r}(2) \\
\text { Mode102 }\end{array}$ \\
\hline edad & $\begin{array}{l}0.7480 \\
(1.85)\end{array}$ & \\
\hline edad2 & $\begin{array}{l}-0.0068 \\
(-1.33)\end{array}$ & \\
\hline mujer & $\begin{array}{l}-4.9642 * * \\
(-3.30)\end{array}$ & $\begin{array}{l}-3.8724^{*} \\
(-2.51)\end{array}$ \\
\hline _Iestrato2_2 & $\begin{array}{l}0.6436 \\
(0.29)\end{array}$ & \\
\hline _Iestrato2_3 & $\begin{array}{l}-1.7964 \\
(-1.03)\end{array}$ & \\
\hline educ1 & $\begin{array}{l}1.4958 \\
(0.88)\end{array}$ & \\
\hline qhijos & $\begin{array}{l}-0.8434^{*} \\
(-2.44)\end{array}$ & $\begin{array}{l}-0.3231 \\
(-0.96)\end{array}$ \\
\hline tiempo & $\begin{array}{l}-0.0444 \\
(-0.48)\end{array}$ & \\
\hline _cons & $\begin{array}{l}29.8745^{* * *} \\
(3.70)\end{array}$ & $\begin{array}{l}45.9283^{* *} \\
(33.00)\end{array}$ \\
\hline $\begin{array}{l}\mathrm{N} \\
\mathrm{r} 2 \\
\mathrm{~F}\end{array}$ & $\begin{array}{r}219 \\
0.0828 \\
3.5312\end{array}$ & $\begin{array}{r}231 \\
0.0275 \\
3.2677\end{array}$ \\
\hline
\end{tabular}


Se estimaron modelos econométricos que cuantifican la influencia de la edad, el género, el país de residencia de los emigrantes dominicanos, el nivel educativo, la cantidad de hijos y el tiempo de residencia en el país receptor. Se obtuvo como resultado que ser mujer y la cantidad de hijos influye negativamente sobre la cantidad de horas trabajadas por semana. El nivel de educación -medida por la variable que distingue entre calificados y no calificados (con educación igual o superior a universitaria) - no resultó ser significativo. Se realizó una prueba de igualdad de medias de la cantidad de horas trabajadas para los no calificados (42.6 horas) y para los calificados (44.7 horas) y el resultado [ver anexo 3] arrojó que no hay una diferencia estadísticamente significativa. En 2011, la cantidad de horas trabajadas en Puerto Rico era de 42.3, en Estados Unidos 44.0 y en España 44.1 horas. El modelo concluye que esas diferencias por país receptor no son estadísticamente significativas.

\section{¿QUIÉN PERDIÓ EL TRABAJO ENTRE 2008 Y 2011?}

El 69.5\% de los entrevistados declaró que estuvo trabajando en el 2008 mientras que el 64.5\% declaró estarlo en el 2011, equivalente a una disminución de 5 puntos porcentuales en la proporción de personas trabajando. De las personas que declararon estar trabajando en el 2008, el 25.5\% indicó estar sin empleo en 2011. Adicionalmente, de los que declararon no estar trabajando en el 2008, el 58.2\% permaneció sin empleo en el 2011 y el restante $41.8 \%$ consiguió un puesto de trabajo.

Tabla N. ${ }^{\circ} 9$

Personas trabajando en 2008 y 2011 (cifras en \%)

\begin{tabular}{|c|c|c|c|c|}
\hline & & Trabaj & 2011 & \\
\hline & & No & $\mathbf{S i}$ & Total \\
\hline & Si & 25.5 & 74.5 & 100.0 \\
\hline & No & 58.2 & 41.8 & 100.0 \\
\hline & Total & 35.5 & 64.5 & 100.0 \\
\hline
\end{tabular}


$\mathrm{Al}$ descomponer por país, España experimentó el mayor cambio en su ponderación de población empleada. En ese país, el $45 \%$ de quienes estaban empleados en el 2008 pasó a estar desempleado en el año 2011, frente a 16.8\% en EE.UU. y 15.5\% en Puerto Rico. Si se divide la población en no calificados (con educación hasta secundaria) y calificados (con educación universitaria), no se observa una diferencia significativa en el porcentaje de población que perdió el empleo entre ambos años. De los no calificados que estaban trabajando en el 2008, el 25.9\% no estaba empleado en el 2011, mientras que de los calificados que estaba trabajando en el 2008 el $24.1 \%$ no lo estaba en el 2011. No obstante, se nota una diferencia mayor en la capacidad de conseguir un empleo para los menos calificados que estaban desempleados en el 2008. Del grupo poblacional no calificado sin trabajo en el 2008, el 45.1\% consiguió un empleo en el 2011. Por su parte, de la población calificada sin empleo en el 2008, solo el 39\% consiguió emplearse en el 2011. En términos de género, la mujer fue quien principalmente pasó a estar desempleada en 2011. De las mujeres con empleo en el 2008, el 30.9\% declaró estar desempleada en el 2011. De los hombres con trabajo en el 2008, el 20.3\% afirmó estar sin empleo en el 2011. El hombre desempleado en el 2008 también consiguió en mayor proporción $(56.3 \%)$ un empleo en el 2011que la mujer (30.7\%).

El tiempo promedio desempleado es de 15.2 meses o aproximadamente 1 año y 3 meses. Tanto España como Puerto Rico se encuentran por encima de la media con 15.6 y 17.1 meses, respectivamente. En Estados Unidos el tiempo promedio desempleado es de 14 meses. Por nivel de educación, se observa que el tiempo promedio desempleado se reduce al pasar de primaria (19 meses) hasta el nivel de postgrado (14.7 meses). Por género, el hombre (13.6 meses) tiene un tiempo promedio desempleado menor que la mujer (16.3 meses). 


\section{Gráfico N. ${ }^{\circ} 10$}

Porcentaje de personas con empleo en el 2008 y que actualmente se encuentran desempleadas

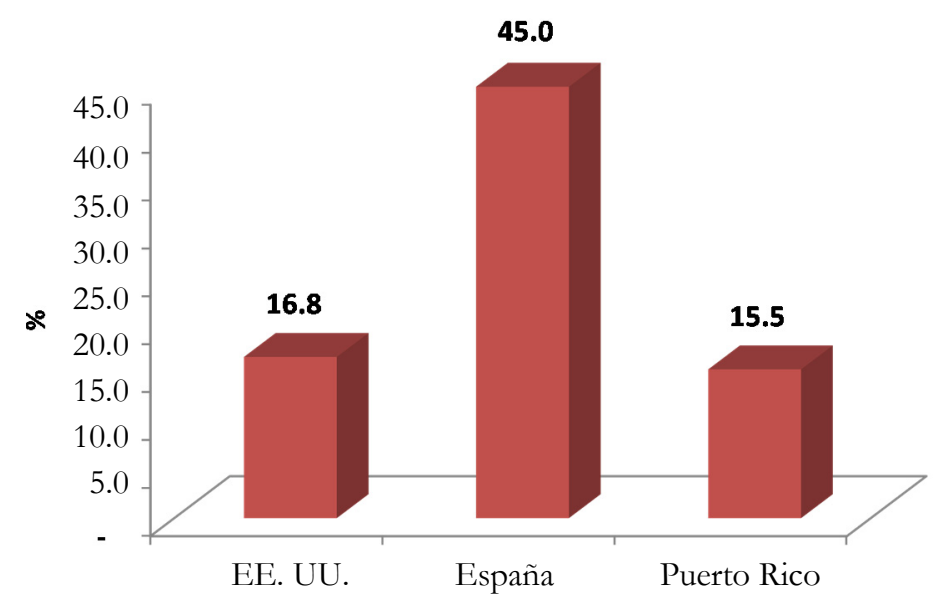

Gráfico N. ${ }^{\circ} 11$

Duración media del desempleo en meses

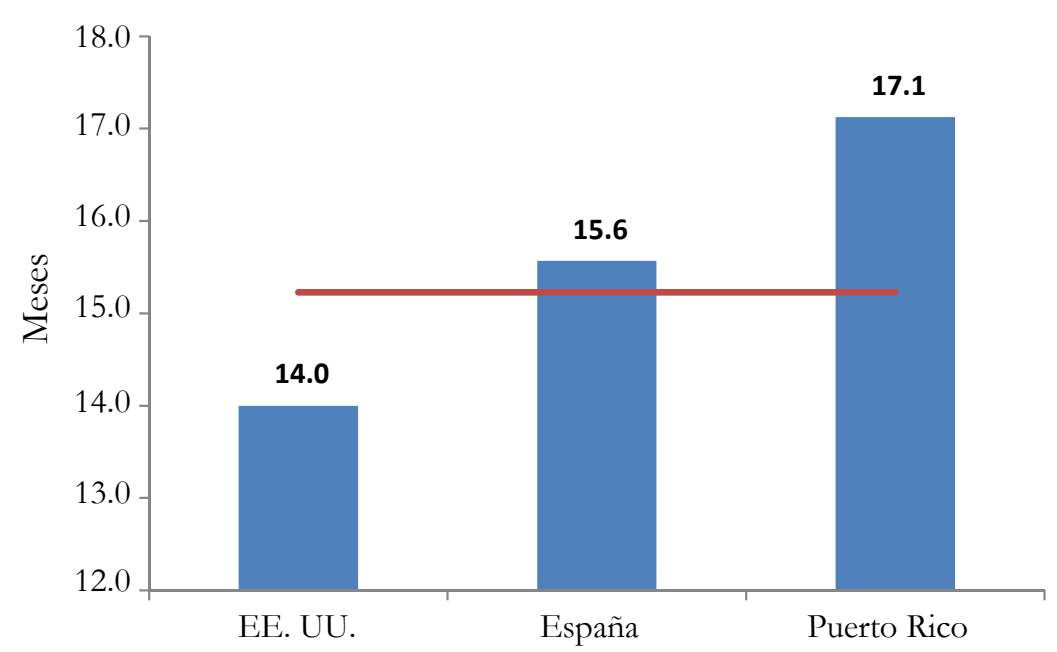

Como se observa en el gráfico $\mathrm{N}^{\circ} 12$, aunque una alta proporción de los desempleados lo estaba por razones personales y de estudio, el $44.8 \%$ de las razones se debe a un mercado laboral 
apretado. La mayor proporción se concentra en personas que no ha encontrado trabajo (21\%), seguido por la pérdida del empleo $(17.1 \%) \mathrm{y}$, finalmente, el cierre del lugar de trabajo (6.7\%). Al descomponer por país, en España el 25\% de los que no están trabajando declararon que perdieron el trabajo y el 36.4\% afirmó que no ha encontrado trabajo. Esas respuestas contrastan con las de dominicanos en Estados Unidos (12\% perdió el trabajo y 6\% no ha encontrado trabajo). En Puerto Rico, el 27.3\% declara que no está trabajando porque cerraron la empresa y el 27.3\% afirma que no ha encontrado trabajo. Al diferenciar por género, el $25 \%$ de las mujeres afirma que no está trabajando por razones personales, mientras que solo declara algo similar el 8.1\% de los hombres. Las razones laborales afectan más al hombre (59.5\%) que a la mujer (36.8\%). Si se divide la población en no calificados (hasta educación secundaria) y calificados (universitaria), el 40\% de los calificados que no está trabajando declara no estarlo porque estaba o está estudiando y el 34.6\% aduce razones vinculadas con un mercado laboral apretado. En contraste, el 53.2\% de los menos calificados declara que no está trabajando por razones relacionadas al mercado laboral.

\section{Gráfico N. ${ }^{\circ} 12$}

\section{Razón por la cual los desempleados declararon estarlo}

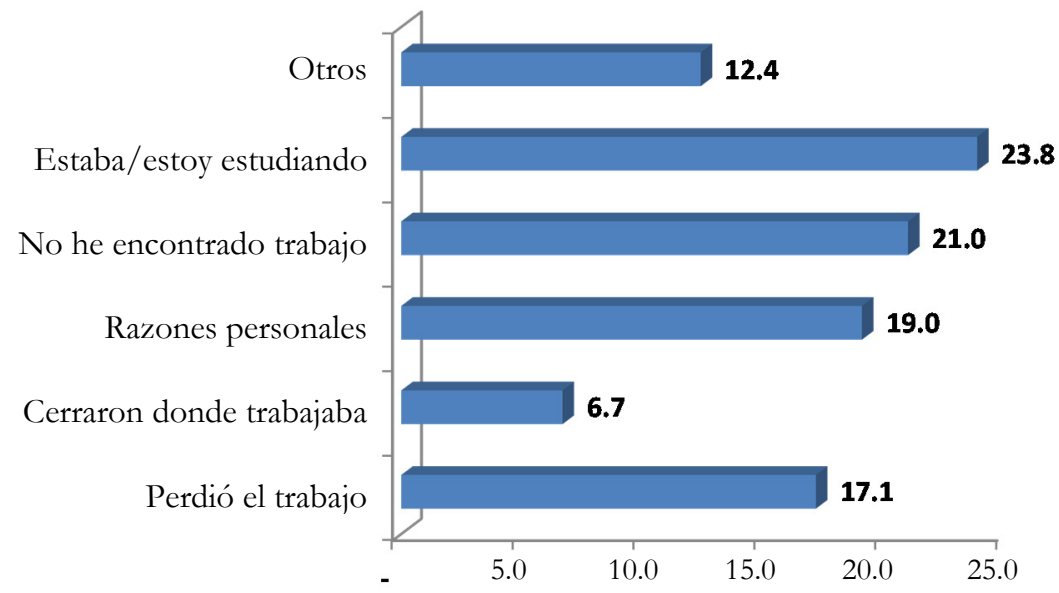


De las personas que se encontraban trabajando en el 2008 y que actualmente continúan empleados, el $62.8 \%$ permaneció con el mismo empleo mientras que el restante $37.2 \%$ cambió de trabajo. $\mathrm{Al}$ analizar la razón de cambio de estos últimos, se observa que la mayoría (39.7\%) lo hizo por mejores condiciones. El 17.6\% cambió debido a que cerraron el lugar donde trabajaba y el $13.2 \%$ porque perdió su empleo anterior.

\section{Gráfico $N{ }^{\circ} 13$}

Cambió o no permanece con el mismo empleo y razón de cambios de empleo

(cifras en \%)
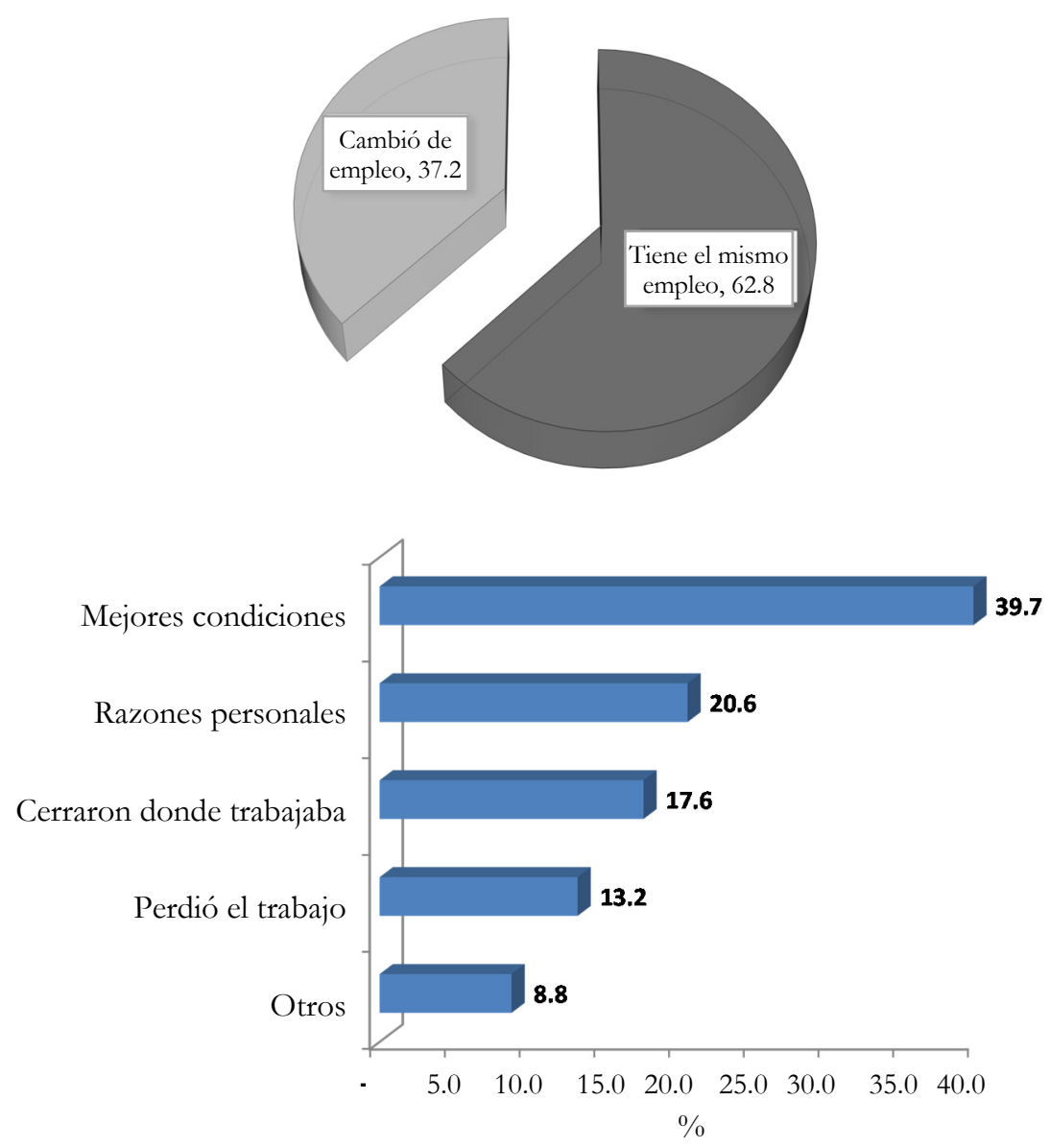

520 Ciencia y Sociedad 2015; 40(3): 477-563 


\section{Gráfico N. ${ }^{\circ} 14$ \\ Proporción de personas con empleo con mucha preocupación de perderlo}

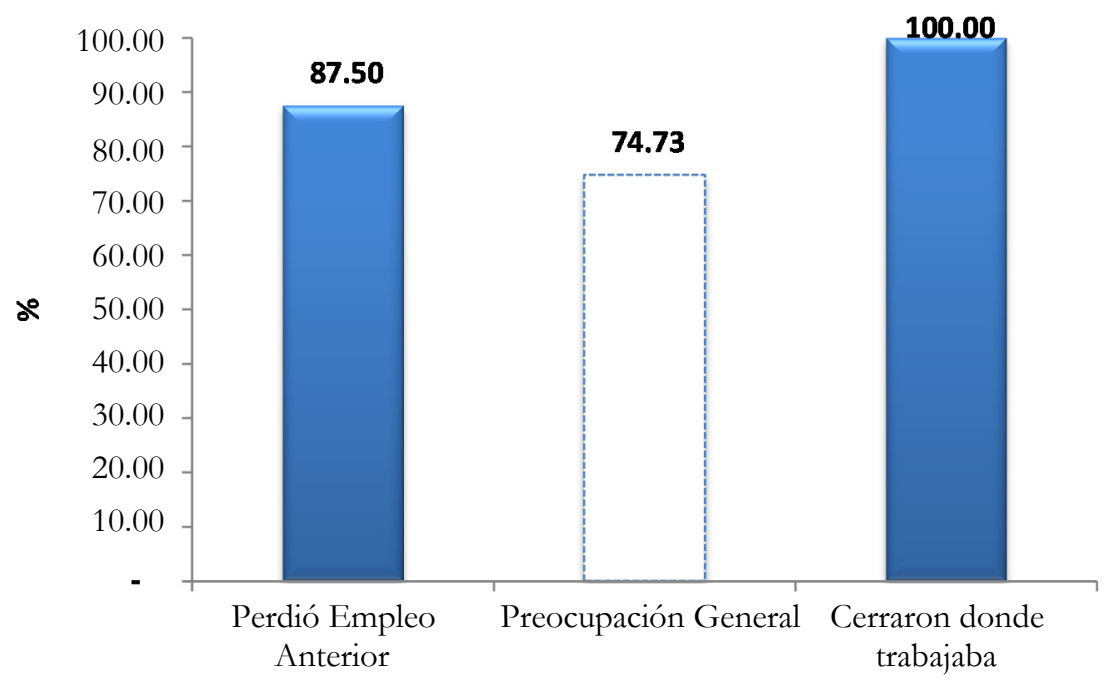

El 74.7\% de las personas con empleo expresa estar muy preocupado con la posibilidad de perder su trabajo. A una mayor proporción de mujeres $(77.2 \%)$ que de hombres $(72.8 \%)$ le preocupa mucho perder su empleo. En Puerto Rico (90.9\%) existe una mayor proporción de personas que le preocupa mucho perder su empleo. A una mayor proporción de menos calificados (77.6\%) que de calificados $(73.8 \%)$ les preocupa mucho perder su trabajo. En general, la preocupación es mucho más acentuada entre aquellos que experimentaron movilidad laboral asociada a pérdida del empleo anterior (87.5\% expresó mucha preocupación) y por cierre de su lugar anterior de trabajo (el 100\% expresó mucha preocupación). 
EL MERCADO LABORAL DE LOS ESTADOS UNIDOS ES MÁS FLEXIBLE AL LLEVAR A CABO AJUSTES SALARIALES PARA CONSERVAR EMPLEO

El concepto de flexibilidad laboral es bastante amplio y existen definiciones diversas dentro de la literatura. Ese concepto puede tomar varias formas que incluyen, entre otras cosas, la adaptabilidad de los agentes económicos a los ciclos económicos así como la flexibilidad de los salarios nominales (o reales) y costos no salariales ante las distintas circunstancias económicas que pueden predominar.

En el contexto de esta investigación, se evalúa la flexibilidad del mercado laboral desde la dimensión de los salarios nominales. Al preguntar sobre los ingresos y cantidad de horas trabajadas previo y durante la crisis económica para cada uno de los países cubiertos, se observa el cambio en el ingreso por hora y se evalúa en función de la situación de empleo de cada área geográfica.

Al analizar el ingreso por hora promedio, se nota que esa variable pasó en términos nominales de 14.44 dólares por hora en 2008 a 13.79 dólares por hora en 2011, una caída de 4.5\%. Al calcular el ingreso/hora descontado con una inflación promedio de $2 \%$ anual, se obtiene un ingreso/hora de 12.99 dólares por hora equivalente a una caída de $10 \%$ en términos reales. Lo anterior refleja un ajuste salarial en el mercado laboral que pudiera explicarse por la recesión económica provocada por la crisis financiera. Es importante tomar en cuenta que esos promedios solo toman en consideración aquellos que individuos que se encuentran empleados.

Tabla N. ${ }^{\circ} 10$

Ingreso por hora en dólares

$\begin{array}{lrrrr} & \text { EE.UU. } & & & \\ 2008 & 20.44 & 9.53 & 10.75 & 14.44 \\ 2011 & 17.4 & 9.57 & 10.75 & 13.79 \\ 2011 \text { - Real } & 16.40 & 9.02 & 10.13 & 12.99 \\ \text { Var. Real } & -19.8 \% & -5.4 \% & -5.8 \% & -10.0 \% \\ \text { Var. Nominal } & -14.9 \% & 0.4 \% & 0.0 \% & -4.5 \%\end{array}$


$\mathrm{Al}$ descomponer por percentil, la reducción se explica principalmente por caídas en el ingreso por hora de los más ricos. De hecho se observa que hasta el percentil $25 \%$ se registró un aumento del ingreso por hora en términos nominales entre 2008 y 2011. En términos reales el ingreso por hora del año 2011 percibido por las personas con remuneraciones correspondientes hasta el percentil 25\% se quedó constante con relación al año 2008.

Tabla N. ${ }^{\circ} 11$

Ingreso por hora 2008 y 2011 por percentiles

Ingreso/hora en 2008

Percentiles Smallest

\begin{tabular}{rrr}
\hline $1 \%$ & 3.06 & 2.5 \\
$5 \%$ & 4.17 & 2.6 \\
$10 \%$ & 5 & 3.06 \\
$25 \%$ & 6.88 & 3.68
\end{tabular}

$50 \%$

9.8

$75 \%$

$90 \%$

$95 \%$

$99 \%$

\begin{tabular}{rr}
\multicolumn{2}{c}{ Largest } \\
15.63 & 70.84 \\
27.5 & 100 \\
38.46 & 100 \\
100 & 150
\end{tabular}

14.44
Ingreso/hora en 2011

Percentiles Smallest

\begin{tabular}{rrr}
\hline $1 \%$ & 3.6 & 2.66 \\
$5 \%$ & 4.89 & 3.33 \\
$10 \%$ & 5.54 & 3.6 \\
$25 \%$ & 7.22 & 3.88
\end{tabular}

$50 \%$

9.38

\begin{tabular}{rrr} 
& \multicolumn{2}{c}{ Largest } \\
$75 \%$ & 17.87 & 50 \\
$90 \%$ & 25 & 55.56 \\
$95 \%$ & 37.5 & 62.5 \\
$99 \%$ & 55.56 & 75
\end{tabular}

Promedio:

Promedio:

13.79

Los Estados Unidos fue el país que exhibió mayor flexibilidad salarial. El salario por hora promedio pasó de 20.4 dólares por hora en el 2008 a 17.4 dólares por hora en 2011, equivalente a una reducción nominal de $14.7 \%$ o $19.6 \%$ en términos reales (descontando con 2\% de inflación anual). Ese resultado indica que el mercado laboral de los Estados Unidos es más flexible, ajustándose más rápido el salario por hora a la baja mediante lo cual se logra recuperar empleo más rápido que en España y Puerto Rico. 
3.4.3 Impacto sobre los ingresos y la calidad de vida del dominicano emigrante

\section{ANÁLISIS DE INGRESOS}

En la encuesta se preguntó a los emigrantes sobre su ingreso percibido en el año 2011 y el recibido previo a la crisis. En términos nominales, el ingreso promedio mensual percibido en 2011 asciende a 2,011 dólares. En el 2008, el ingreso mensual promedio era de 2,616 dólares. Esto implica una caída acumulada de $-23.1 \%$ del ingreso promedio en términos nominales. En términos reales, descontando tres años a una tasa de inflación promedio de $2 \%$, la variación sería de $-27.6 \%$. Al descomponer por países se tiene como resultado que en España (-25\%) y Estados Unidos (-24.8\%) se registran mayores descensos del ingreso nominal que en Puerto Rico $(-21.5 \%)$. El género también es una variable que influye sobre el nivel de los ingresos. La mujer tiene un nivel de ingresos promedio en 2011 de 1,636 dólares, mientras que el hombre percibe 2,371.6 dólares. Además, la caída de los ingresos nominales entre 2008 y 2011 fue mayor para la mujer (-26.8\%) que para el hombre $(-20.3 \%)$. Al diferenciar a las personas por nivel de calificación se obtiene como resultado que los calificados $(-28.5 \%)$ experimentaron un mayor descenso de sus ingresos que los no calificados (-17.8\%) debido a la Gran Recesión. 
El impacto de la Gran Recesión sobre los migrantes dominicanos

Gráfico $\mathbf{N}^{\circ} 15$

Ingreso promedio mensual en US\$ previo al 2008 y en el 2011
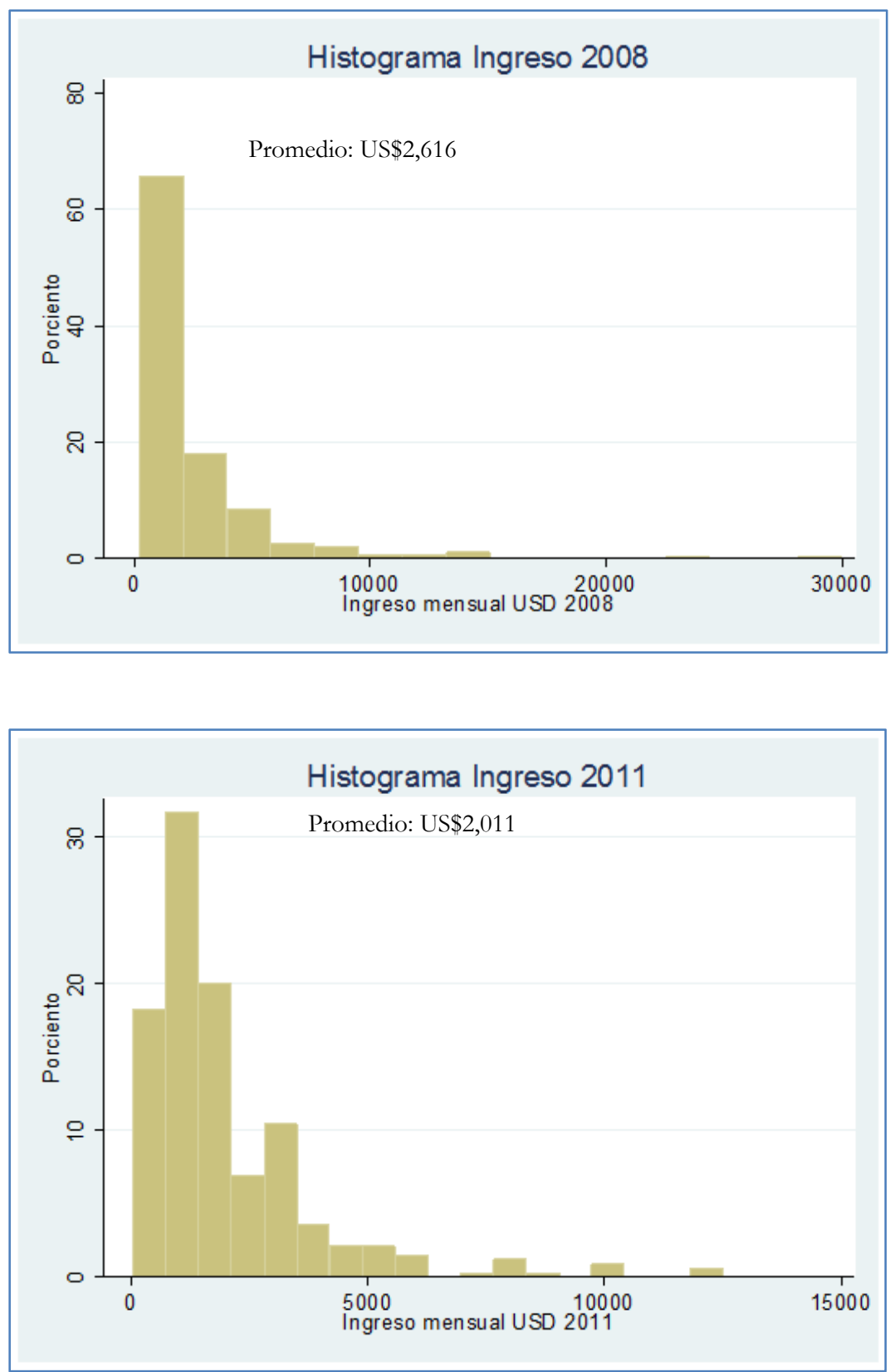

Ciencia y Sociedad 2015; 40(3): 477-563 525 


\section{Gráfico $\mathbf{N} .^{\circ} 16$ \\ Variación del ingreso mensual}

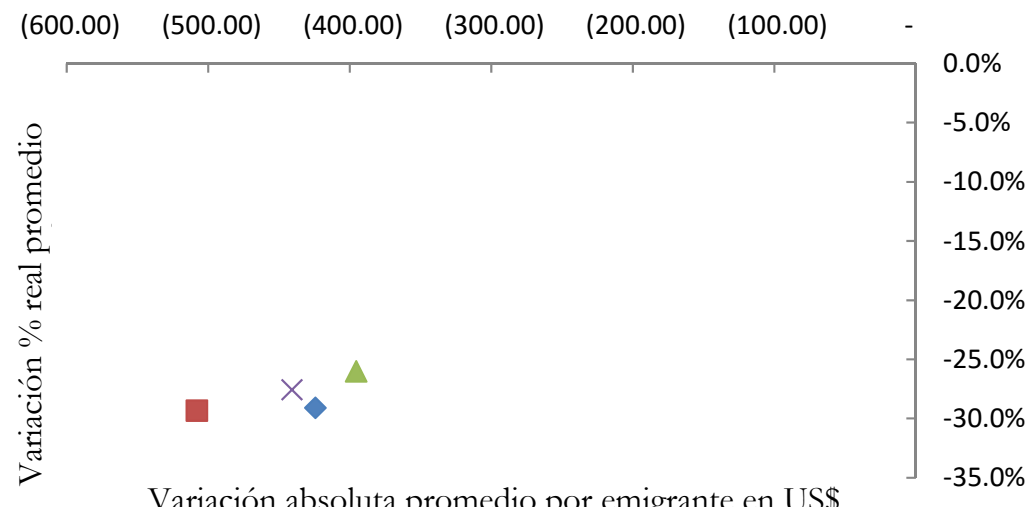

$\diamond$ EE.UU. España $\triangle$ Puerto Rico $\times$ Total

La principal fuente de ingresos de la familia son los sueldos de miembros del hogar. El $72.4 \%$ de los emigrantes dominicanos entrevistados declaró que el ingreso es su principal fuente de ingresos. La proporción de entrevistados para el resto de las fuentes de ingresos es baja (ver gráfico N. ${ }^{\circ} 17$ ), siendo la segunda fuente de ingresos los trabajos ocasionales.

\section{Gráfico N. ${ }^{\circ} 17$}

Fuentes de ingreso con que cuenta la familia (\% que respondieron Sí)

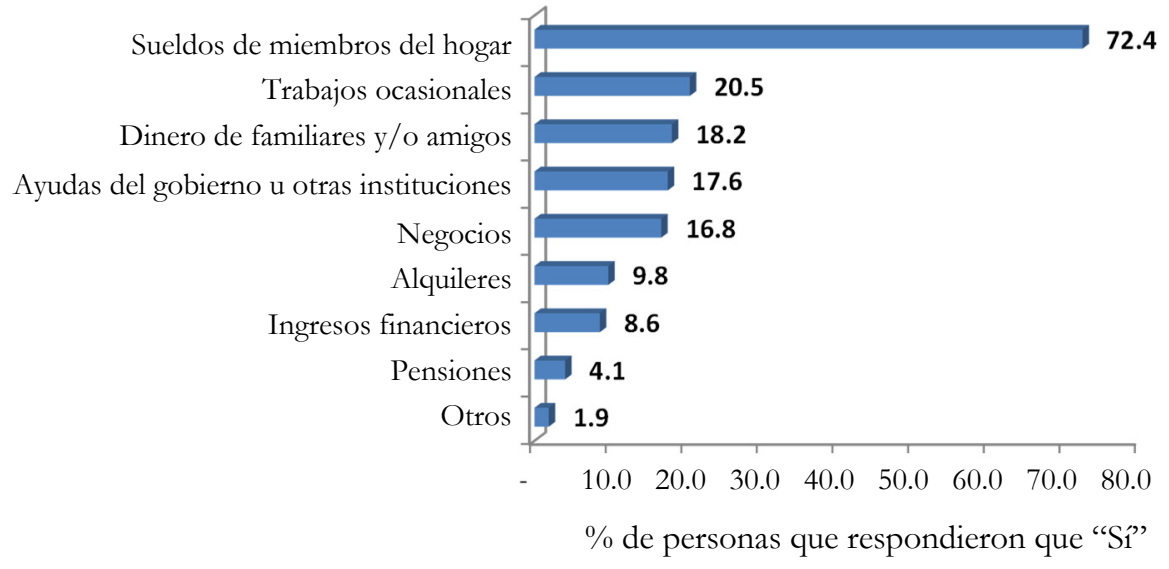


Considerando todas las fuentes de ingreso, el ingreso promedio del hogar asciende a 3,264 dólares mensuales. A nivel de cada país, los Estados Unidos muestra el mayor ingreso promedio por hogar con 4,572 mensuales dólares, seguido por Puerto Rico con 2,711 dólares y finalmente España con 1,893 dólares.

\section{Gráfico N. ${ }^{\circ} 18$}

Ingreso promedio mensual del hogar (US\$)

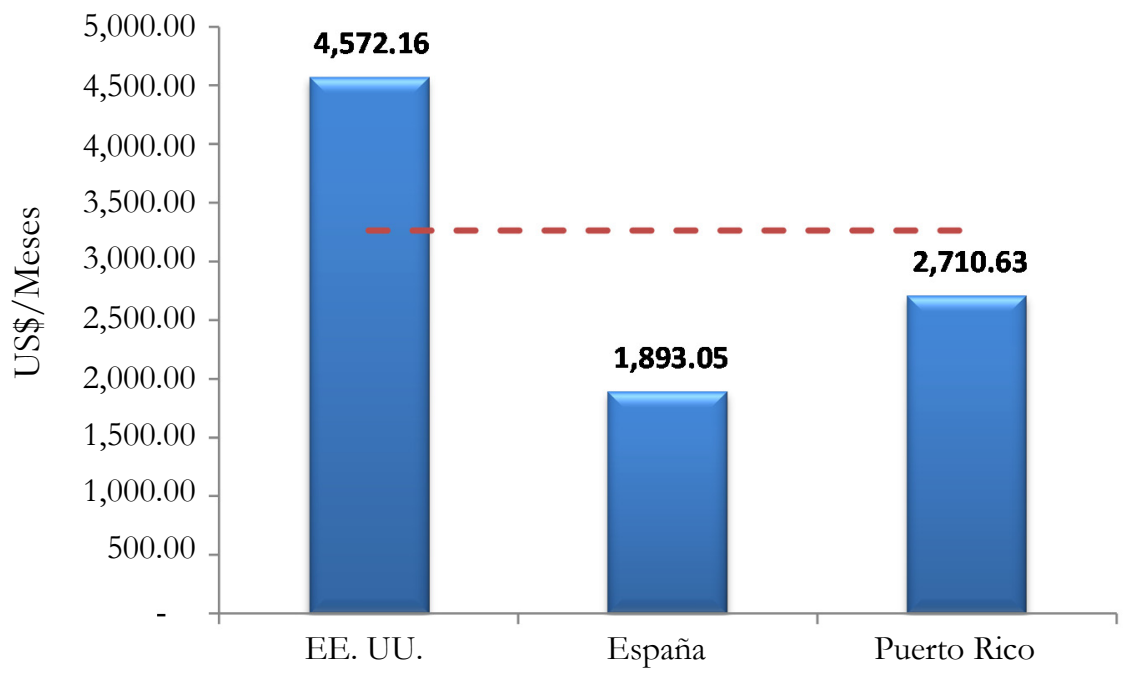

A nivel general, el 54.2\% de los emigrante dominicanos declara poder cubrir sus gastos y los de su familia, aunque de ese porcentaje solo una minoría (17.8 puntos porcentuales) afirma que lo hace de manera desahogada. Se corrió un modelo logístico multinomial para determinar si estar trabajando mejora el grado de satisfacción con los ingresos. La variable dependiente -grado de satisfacción con los ingresos- tiene cuatro categorías:

a) Lo que gano me permite llevar una vida desahogada;

b) Lo que gano me permite cubrir mis gastos y los de mi familia;

c) Lo que gano apenas me da para llegar a cubrir mis gastos; y

d) Lo que gano no cubre mis necesidades básicas. 
Los resultados del modelo, que se presentan en el anexo 4, sugieren que estar trabajando disminuye la probabilidad de que las personas seleccionen las alternativas c y d; es decir, estar trabajando mejora el grado de satisfacción de la persona con sus ingresos.

En cuanto al ingreso según sector económico, se observa que los trabajadores del sector manufactura generan los mayores ingresos, percibiendo mensualmente en promedio 4,244 dólares..$^{52}$ Los sectores comercio y servicio generan en promedio 2,143 dólares y 2,359 dólares, respectivamente.

\section{Gráfico N. ${ }^{\circ} 19$ \\ Ingreso promedio según sector económico}

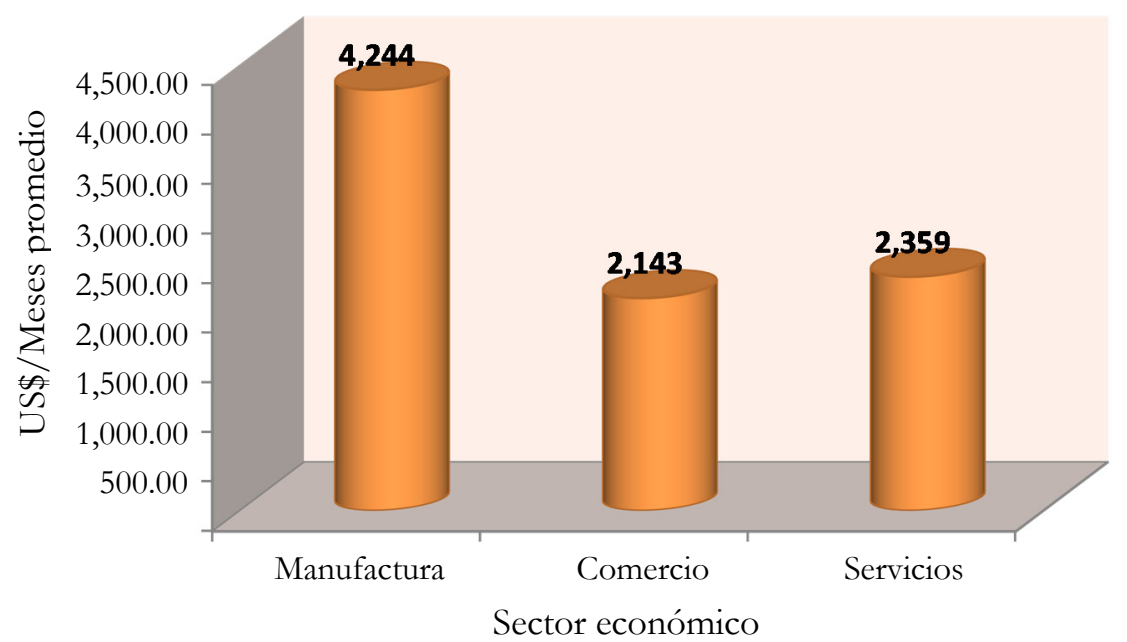

Al evaluar la migración laboral entre sectores económicos, se observa que el mayor movimiento se produjo desde el sector manufactura, donde el 33.4\% migró hacia otro sector económico. En términos generales, el sector de destino más importante fue el de

52 Este dato debe ser tomado con precaución, pues la representatividad del sector manufactura en la muestra resultó ser únicamente de un $2 \%$, mientras que servicios y comercio alcanzaron un $79.8 \%$ y $18.2 \%$, respectivamente. 
servicios. El movimiento desde manufactura hacia comercio y servicios provocó una disminución del ingreso de los trabajadores, pues el ingreso del 2011 de esos dos sectores es inferior al de manufactura.

\begin{tabular}{|c|c|c|c|c|}
\hline Movimient & $\begin{array}{r}\text { Tabla } \\
\text { to laboral en }\end{array}$ & $\begin{array}{l}12 \\
\text { ectore }\end{array}$ & nómic & \\
\hline & Manufactura & 201 & & \\
\hline Manufactura & 66.7 & 16.7 & 16.7 & 100.0 \\
\hline Comercio & 3.0 & 75.8 & 21.2 & 100.0 \\
\hline Servicios & - & 2.8 & 97.2 & 100.0 \\
\hline Total & 2.7 & 16.4 & 80.9 & 100.0 \\
\hline
\end{tabular}

\section{¿HA DETERIORADO LA CRISIS ECONÓMICA LA CALIDAD DEL EMPLEO DEL DOMINICANO EMIGRANTE?}

En la encuesta se preguntó sobre la cantidad de horas trabajadas y el tipo de trabajo realizado entre el 2008 y la actualidad. Como proxy para evaluar la calidad del empleo, se analizó el cambio tanto en las horas dedicadas al trabajo así como el ingreso por hora generado entre ambos momentos del tiempo. En este análisis, un deterioro en la calidad del trabajo implicaría dedicar más horas por simultáneamente menos compensación.

Al evaluar la cantidad de horas que las personas que trabajan en la actualidad dedicaban a sus labores en el 2008 y en la actualidad, puede concluirse que estas dedican prácticamente las mismas horas para ambos momentos en el tiempo. Los encuestados respondieron que en 2008 trabajaban 44.8 horas en promedio y en 2011 laboraban 43.6 horas. Consecuentemente, desde el punto de vista de horas dedicadas al trabajo, no han sufrido un deterioro significativo.

Sin embargo, a pesar de que la cantidad de horas se mantuvo invariable en promedio, el ingreso generado por cada hora de trabajo 
es menor. En el 2008, el ingreso promedio por hora estuvo en 14.44 dólares (con un mínimo de 2.5 dólares y un máximo de 150 dólares) y pasó a 13.79 dólares para el 2011 (con un mínimo de 2.66 dólares y un máximo de 75 dólares), lo que equivale a una caída de $-4.5 \%$ en términos nominales y $-10 \%$ en términos reales.

La conclusión anterior, junto con el hecho de que existe un alto nivel de preocupación de perder el empleo sitúa al emigrante dominicano en una situación laboral peor a la que tenía previo a la crisis económica.

\section{¿PROVOCó LA CRISIS DE BIENES RAÍCES UNA PÉRDIDA DE RIQUEZA} AL DOMINICANO RESIDENTE EN EL EXTERIOR?

\section{Vivienda}

La mayoría de los entrevistados no tiene vivienda propia, sino que paga alquiler (66.7\%). Lo anterior reduce el impacto de la crisis sobre el nivel de riqueza de los dominicanos en sentido general. $\mathrm{Al}$ descomponer por país, España es donde se presenta menor porcentaje de dominicanos con vivienda propia (12.8\%). En los Estados Unidos y Puerto Rico, la proporción es de 40.3\% y 41.6\%, respectivamente.

Para evaluar la pérdida de viviendas entre la población emigrante, se preguntó si se tenía vivienda propia en el 2008 y si la pudo conservar en medio de la crisis financiera. El 77.8\% de los entrevistados declaró no tener vivienda en el 2008. Al comparar los dos años bajo análisis, se observa que el porcentaje de entrevistados con vivienda propia se incrementó al pasar de $22.2 \%$ en 2008 a un $31.5 \%$ en 2011. Esto significa que, a pesar de la crisis de bienes raíces, los dominicanos lograron aumentar su tenencia de vivienda propia. Específicamente, de los que declararon no tener vivienda propia en 2008 un 14\% afirmó que sí tenía vivienda propia en 2011. 
Gráfico N. ${ }^{\circ} 20$

Proporción de tenencia de vivienda (cifras en \%)

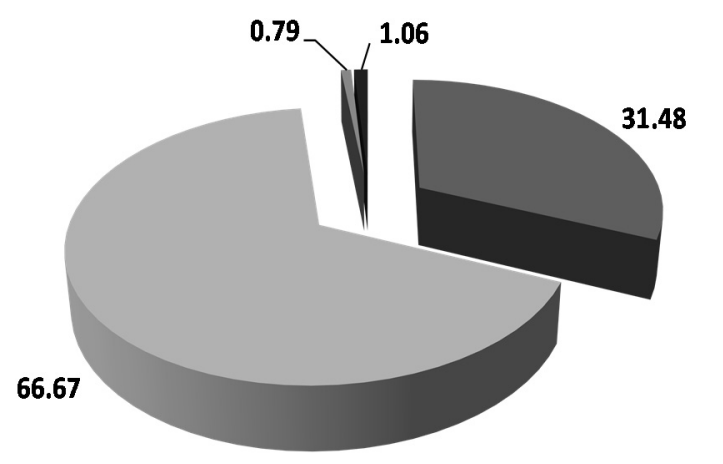

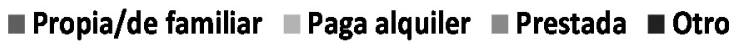

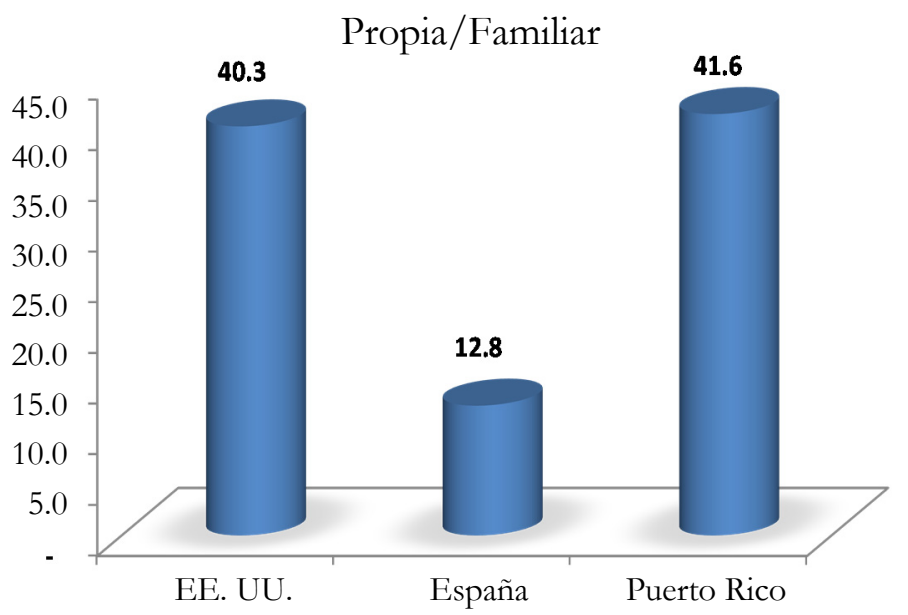

Dentro del grupo que declaró tener vivienda propia (o de algún familiar) en 2011, el 96.1\% declaró haberla conservado en medio de la crisis económica. Las proporciones a nivel de las geografías cubiertas son similares. Como se muestra en el gráfico N. ${ }^{\circ} 21$, las tres áreas geográficas caen en el cuadrante inferior derecho del gráfico, reflejando una baja proporción de tenencia propia y alto porcentaje que la pudo conservar. 


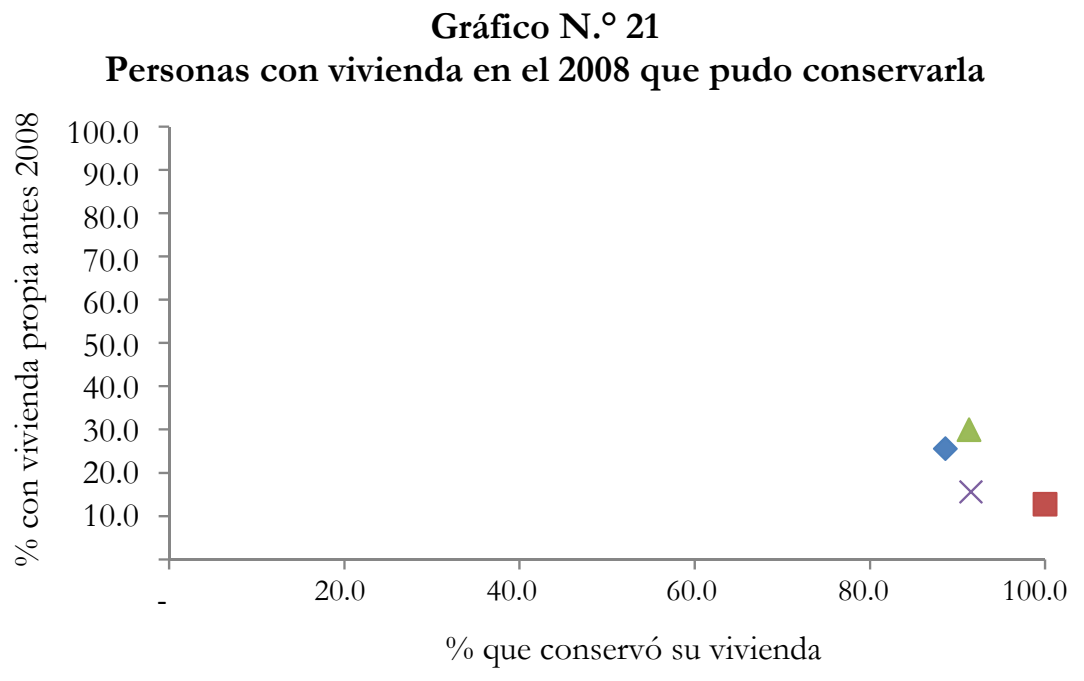

$\diamond$ EE.UU. España $\triangle$ Puerto Rico $\times$ Total

Dentro del grupo de personas que declaró haber perdido su vivienda, el 42.9\% indicó que el banco la ejecutó y el restante 57.1\% la tuvo que vender (en España el 100\% conservó su vivienda).53

Tabla N. ${ }^{\circ} 13$

Forma de pérdida de la vivienda entre aquellos que declararon haberla perdido

(cifras en \%)

\begin{tabular}{|lrrr|} 
& EE.UU. & Puerto Rico & \multicolumn{1}{c|}{ Total } \\
\hline El banco la ejecuto & 40.0 & 50.0 & 42.9 \\
\hline La tuve que vender & 60.0 & 50.0 & 57.1 \\
\hline Total & $\mathbf{1 0 0 . 0}$ & $\mathbf{1 0 0 . 0}$ & $\mathbf{1 0 0 . 0}$ \\
\hline
\end{tabular}

Está claro que el impacto general sobre los dominicanos residentes en el exterior debido a la crisis subprime a nivel de tenencia de vivienda es bajo. Dado que existe una proporción muy pequeña

53 Este resultado debe ser tomado con precaución pues la representatividad de los casos es muy baja.

532 Ciencia y Sociedad 2015; 40(3): 477-563 
de dominicanos con tenencia de vivienda propia, la caída de los precios de los bienes raíces no les produjo un descenso significativo de su riqueza financiera.

En cuanto al endeudamiento, de los entrevistados que posee vivienda propia el $66.2 \%$ declaró tener una deuda hipotecaria al momento de la entrevista. De las personas con deuda hipotecaria, el 84.6\% afirmó que estaba trabajando en el año 2011.

\section{Gráfico $\mathbf{N} \cdot^{\circ} 22$}

Deuda hipotecaria (cifras en \%)

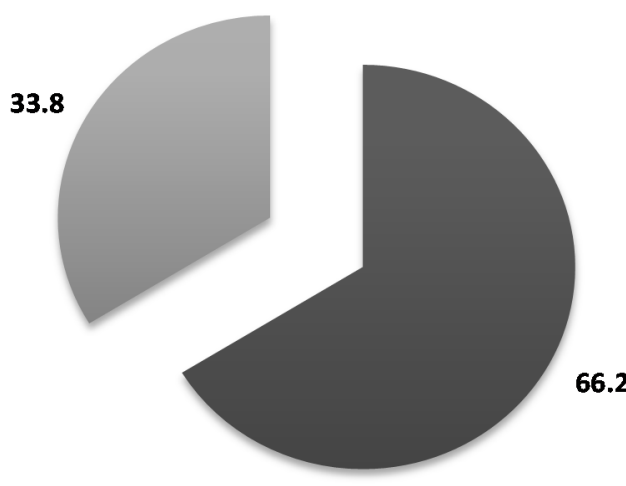

$\square$ Si $\square$ No

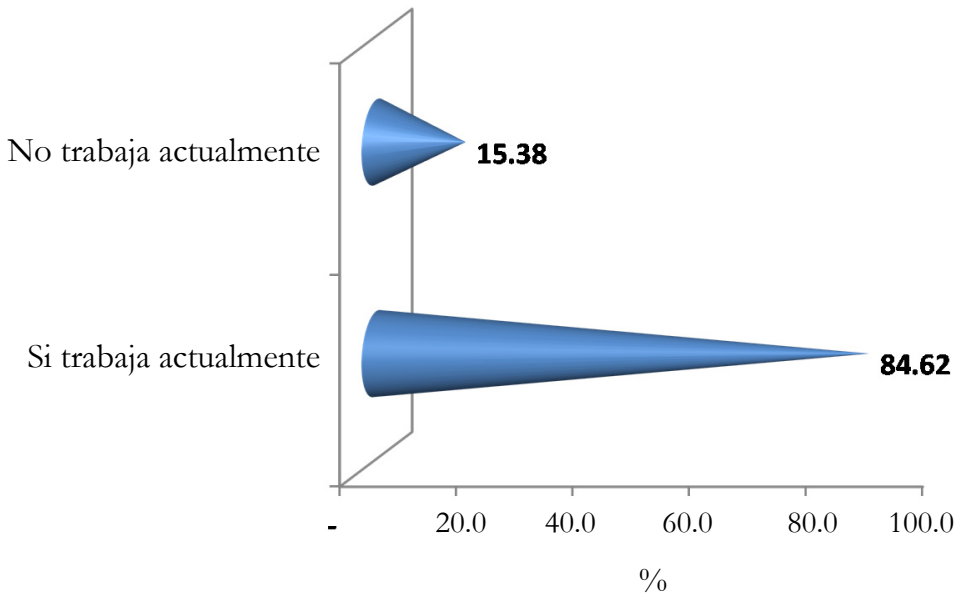


Aun cuando la mayor proporción de quienes poseen deuda hipotecaria se encuentra trabajando en la actualidad, se observa un incremento significativo en el porcentaje de aquellos con la deuda y que no trabajan del 2008 al 2011. En el 2008, el 6.7\% declaró no estar trabajando mientras que para el 2011 la cifra ascendió a $15.3 \%$.

\section{¿LA CRISIS PROVOCÓ UN AUMENTO DEL NIVEL DE ENDEUDAMIENTO?}

El 42\% de los entrevistados declaró tener más deudas en 2011 que antes del 2008. Puerto Rico es el territorio donde se observa mayor incremento de deuda, pues el $61.8 \%$ de quienes respondieron indicó tener en 2011 una mayor deuda. Adicionalmente, se observa que al $28.6 \%$ de aquellos con más deuda le incrementaron la tasa de interés, lo cual indica que en términos de valor presente existe un mayor nivel de endeudamiento fruto de mayor contratación de préstamos y simultáneamente un encarecimiento de la misma.

\section{Gráfico $N{ }^{\circ} 23$}

Porcentaje con mayor endeudamiento que antes del 2008 y que experimentaron un incremento en la tasa de financiamiento

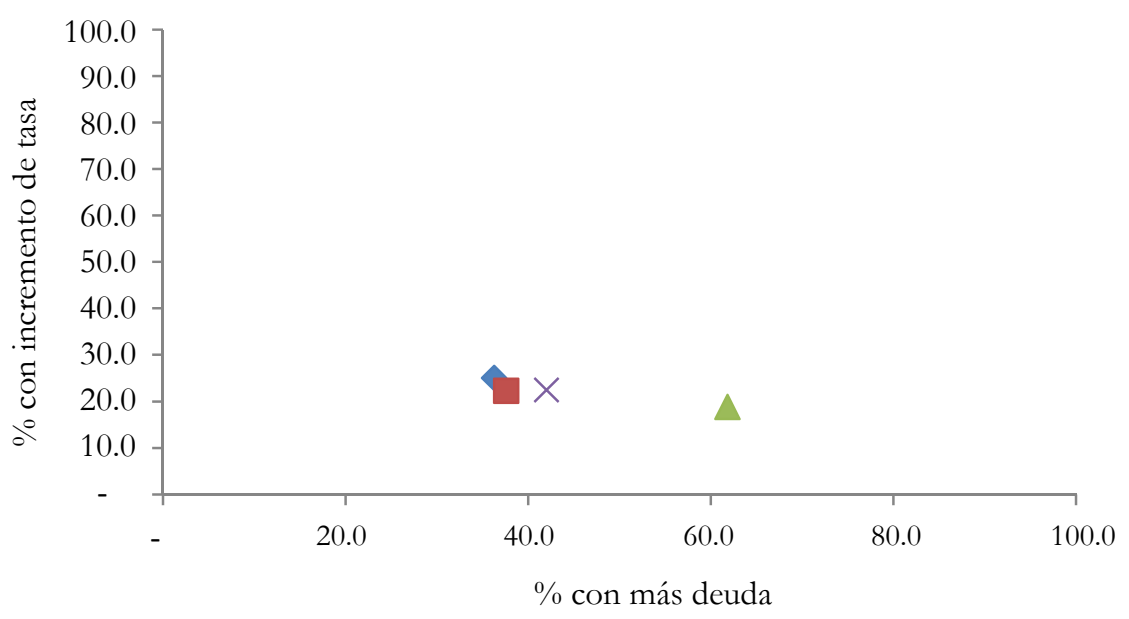

$\diamond$ EE.UU. España $\triangle$ Puerto Rico $\times$ Total 
Adicionalmente, los entrevistados declaran tener una percepción de que ahora es más difícil poder conseguir un préstamo (61.7\%). $\mathrm{Al}$ descomponer por territorio, se obtiene como resultado que en Puerto Rico $(76.6 \%)$ y en España $(75 \%)$ existe mayor percepción de dificultad para obtener un préstamo, en contraste con los Estados Unidos, donde solo el $46.3 \%$ de la población entrevistada respondió que en 2011 era más difícil obtener un préstamo con relación a 2008 .

\section{¿LA CRISIS FINANCIERA AFECTÓ EL PATRÓN DE COMPORTA- MIENTO Y CONSUMO DE LOS DOMINICANOS RESIDENTES EN EL EXTERIOR?}

En la encuesta realizada se preguntó sobre los patrones de consumo de la población emigrante. Los factores evaluados fueron los siguientes:

Tabla N. ${ }^{\circ} 14$

Elementos evaluados respecto a patrones de comportamiento

\begin{tabular}{|l|l|}
\hline \multicolumn{1}{|c|}{$\begin{array}{c}\text { Elementos de consumo } \\
\text { de bienes y servicios }\end{array}$} & \multicolumn{1}{c|}{ Otros elementos } \\
\hline Comer fuera de la casa menos veces & $\begin{array}{l}\text { Tomar dinero prestado a presta- } \\
\text { mista o familiares/amigos }\end{array}$ \\
\hline Reducir compras de Navidad & Ayudar a otros a conseguir préstamo \\
\hline $\begin{array}{l}\text { Posponer o cancelar planes de compras } \\
\text { grandes (carro, vivienda, etc.) }\end{array}$ & Tomar ayudas del gobierno \\
\hline $\begin{array}{l}\text { Comprar menos artículos electrodomés- } \\
\text { ticos y similares }\end{array}$ & \\
\hline Comprar menos comida & \\
\hline $\begin{array}{l}\text { Cambiar a los hijos de escuela privada a } \\
\text { pública }\end{array}$ & \\
\hline $\begin{array}{l}\text { Dejar o cambiar de universidad a algún } \\
\text { miembro de la familia }\end{array}$ & \\
\hline $\begin{array}{l}\text { Cancelar viajes a visitar familiares en } \\
\text { República Dominicana }\end{array}$ & \\
\hline $\begin{array}{l}\text { Dejar de hacer inversiones en tierras o } \\
\text { inmuebles }\end{array}$ & \\
\hline Comprar menos ropa y otras cosas & \\
\hline
\end{tabular}


En sentido general, la crisis ha provocado importantes cambios en los patrones de comportamiento de los emigrantes a nivel de los elementos de consumo. Como se puede observar en el gráfico N. ${ }^{\circ} 24$, a nivel de los diez elementos evaluados, en siete de ellos la respuesta dada afecta negativamente el consumo de bienes o servicios, es decir, la persona afirmó haber tenido que aplicar algún cambio a raíz de la crisis económica. El consumo que no cambió está relacionado con los servicios educativos, lo cual puede estar relacionado con el retorno de la educación percibido por los migrantes. ${ }^{54}$ La mayor parte de los entrevistados declaró que, a pesar de la crisis, no cambió a los hijos de escuela o dejó (o cambió) de universidad.

\section{Gráfico N. ${ }^{\circ} 24$ \\ Respuestas a cambios en patrón de comportamiento}

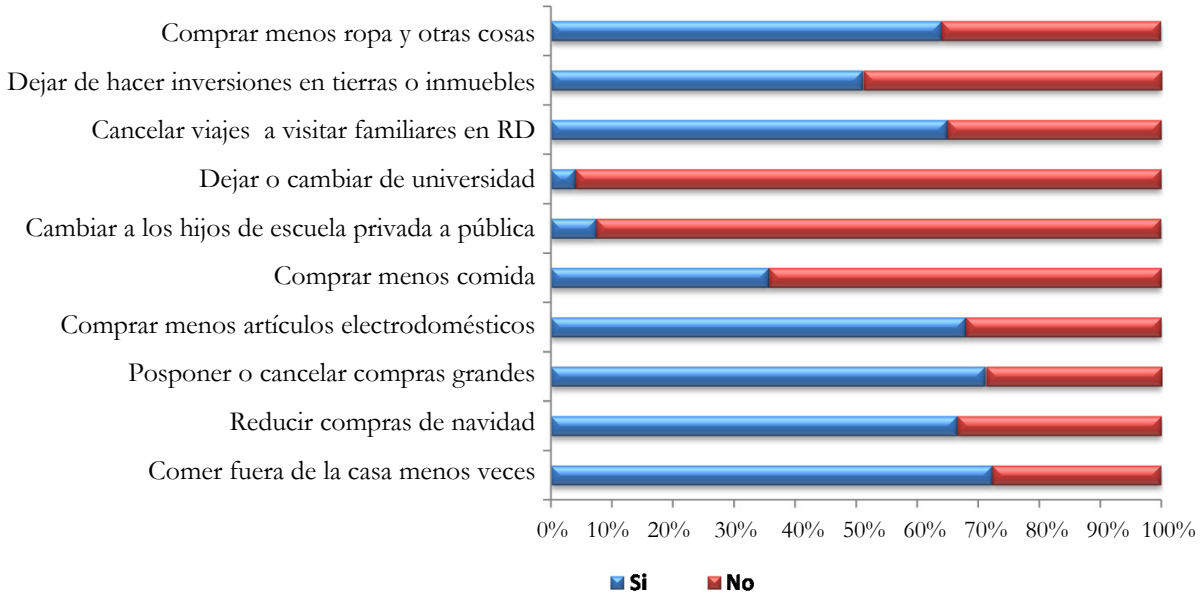

54 En la sección 3.4.4. se presentan los resultados de las estimaciones del retorno de la educación, tomando en consideración la diferencia por país receptor. Esto fue sugerido por Pozo (2015). 
Se observa una marcada diferencia en la proporción de afectados controlando por su condición laboral. Las personas que declararon no estar trabajando al momento de la entrevista afirmaron en mayor proporción cambios en su patrón de consumo. En el caso de la adquisición de ropas y otras cosas, el 70.97\% de los que no trabaja declaró haber disminuido sus compras de ese tipo de bienes, mientras que de los que sí trabaja, el $60.49 \%$ indicó haberlo reducido dichas compras. La diferencia es de 10.47 puntos porcentuales acreditable a la condición laboral.

\section{Gráfico $N{ }^{\circ} 25$ \\ Diferencia entre proporción de afectados negativamente que no trabajan y los que sí trabajan}

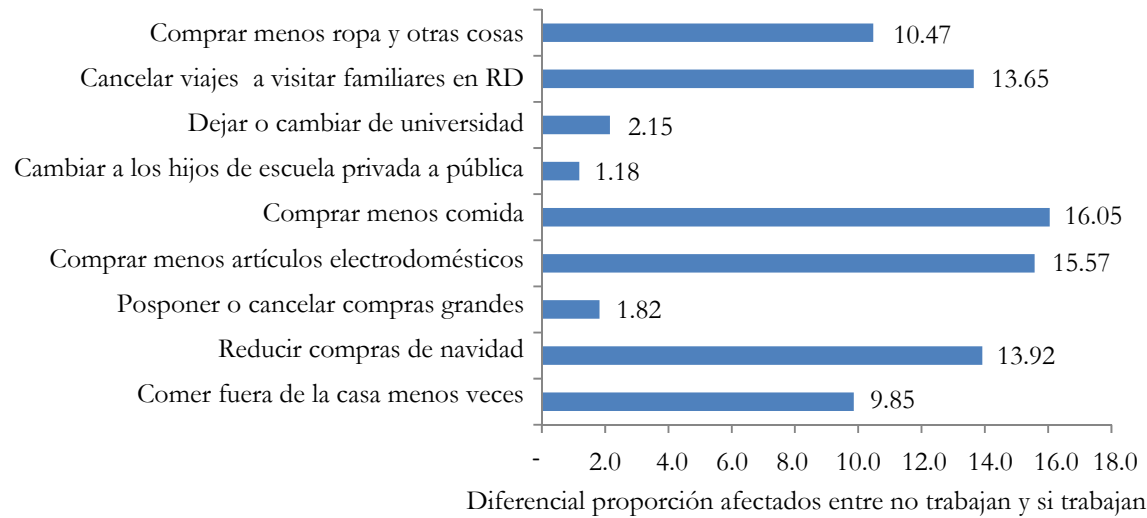

Adicionalmente, se observa también diferencias a nivel de país de residencia. En sentido general, la población residente en España fue la más afectada, reflejándose en el hecho de que en la mayoría de los elementos evaluados existe una proporción más elevada de personas que respondió que debió cambiar su patrón de consumo por la crisis económica. 


\section{Tabla N. ${ }^{\circ} 15$}

Proporción de personas que declararon

estar negativamente afectadas

Según país de residencia

\section{Elemento}

Comer fuera de la casa menos veces

Reducir compras de Navidad

Posponer o cancelar compras grandes.

Comprar menos artículos electrodomésticos

Comprar menos comida

Cambiar a los hijos de escuela privada a pública

Dejar o cambiar de universidad

Cancelar viajes a visitar familiares en RD

Dejar de hacer inversiones en tierras o inmuebles

Comprar menos ropa y otras cosas

\section{Proporción de personas \\ afectadas negativamente}

\begin{tabular}{|c|c|c|c|}
\hline EE.UU. & España & $\begin{array}{c}\text { Puerto } \\
\text { Rico }\end{array}$ & Total \\
\hline 61.21 & 78.23 & 86.84 & 72.33 \\
\hline 58.93 & 75.81 & 68.42 & 66.58 \\
\hline 63.41 & 94.35 & 50.00 & 71.15 \\
\hline 54.55 & 83.87 & 71.05 & 67.95 \\
\hline 32.93 & 29.84 & 51.32 & 35.71 \\
\hline 16.26 & 2.44 & 1.33 & 7.48 \\
\hline 8.06 & 2.44 & - & 4.04 \\
\hline 58.79 & 78.23 & 56.58 & 64.93 \\
\hline 62.42 & 45.97 & 34.67 & 51.10 \\
\hline 64.67 & 62.10 & 65.79 & 64.03 \\
\hline
\end{tabular}

\section{ANÁLISIS DE LA REACCIÓN A LA CRISIS}

En la encuesta se le preguntó a las personas cómo habían reaccionado a la crisis, para identificar el cambio de sus patrones de consumo de bienes y servicios. Los items individuales que preguntan sobre las acciones que debieron tomar los dominicanos ante la crisis (e. g., comer fuera de la casa menos veces, reducir compras de Navidad, posponer o cancelar planes de compras grandes, entre otras) reflejan en conjunto la reacción a la crisis. Esto significa que se puede utilizar el Alpha de Cronbach para agruparlas en una escala única que mida el mismo concepto. El coeficiente de confianza de la escala refleja la correlación entre la presente escala y los items que miden un concepto similar. El valor obtenido para ese coeficiente fue de 0.796 lo cual es considerado como muy bueno. 
Tabla N. ${ }^{\circ} 16$

Coeficiente de confianza

Test scale $=$ mean (unstandardized items)

Average interitem covariance:

Number of items in the scale:

scale reliability coefficient:

.0405028

0.7962

En la siguiente tabla se muestra cómo se relaciona cada item a la escala general. La columna item-test correlation muestra el grado de correlacion de cada item con la escala general. La columna alpha muestra cómo el alpha de la escala cambiaría si se elimase el item de la escala. En este caso se observa que la eliminación de cada item reduciría el valor del alpha, lo que haría la escala menos confiable. Por eso se puede concluir que todos los items deben mantenerse en la escala global.

\section{Tabla N. ${ }^{\circ} 17$}

Indicadores de correlación escala general y alpha de la escala

Test scale $=$ mean (unstandardized items)

\begin{tabular}{l|rccccr}
\multicolumn{1}{l|}{} & \multicolumn{7}{c}{$\begin{array}{c}\text { average } \\
\text { Item }\end{array}$} & obs & Sign & $\begin{array}{c}\text { item-test } \\
\text { correlation }\end{array}$ & $\begin{array}{c}\text { item-rest } \\
\text { correlation }\end{array}$ & $\begin{array}{c}\text { inter-item } \\
\text { covariance }\end{array}$ & a7pha \\
\hline crisis_a & 311 & + & 0.6078 & 0.4950 & .0387087 & 0.7763 \\
crisis_b & 311 & + & 0.7111 & 0.6135 & .0361336 & 0.7636 \\
crisis_c & 311 & + & 0.6294 & 0.5184 & .0381552 & 0.7739 \\
crisis_d & 311 & + & 0.4778 & 0.3670 & .0419413 & 0.7878 \\
crisis_e & 311 & + & 0.3332 & 0.2521 & .0450648 & 0.7951 \\
crisis_f & 311 & + & 0.4900 & 0.3773 & .0416304 & 0.7870 \\
crisis_g & 311 & + & 0.6805 & 0.5788 & .0370011 & 0.7676 \\
crisis_h & 311 & + & 0.6078 & 0.4890 & .0384365 & 0.7768 \\
crisis_i & 311 & + & 0.3911 & 0.3167 & .0445127 & 0.7919 \\
crisis_j & 311 & + & 0.3306 & 0.2782 & .0458281 & 0.7951 \\
crisis_k & 311 & + & 0.5024 & 0.3660 & .0406778 & 0.7893 \\
crisis_1 & 311 & + & 0.4686 & 0.3205 & .0412596 & 0.7946 \\
crisis_m & 311 & + & 0.6575 & 0.5454 & .0371862 & 0.7708 \\
\hline Test scale & & & & & .0405028 & 0.7962 \\
\hline
\end{tabular}

La nueva escala generada, denominada crisis-scale, se utilizó como una variable dependiente de las condiciones de trabajo, el ingreso, el país receptor, la edad, género, la cantidad de hijos, la restricción al acceso al crédito, entre otras variables. Los resultados de la modelización econométrica se presenta en la siguiente tabla. 
Tabla N. ${ }^{\circ} 18$

Modelos de reacción a la crisis

Modelos de reacción a la crisis

\begin{tabular}{|c|c|c|c|c|c|c|c|}
\hline & $\begin{array}{r}(1) \\
\text { Model01 }\end{array}$ & $\begin{array}{r}(2) \\
\text { Model02 }\end{array}$ & $\begin{array}{r}(3) \\
\text { Model03 }\end{array}$ & $\begin{array}{r}(4) \\
\text { Modelo4 }\end{array}$ & $\begin{array}{r}\text { (5) } \\
\text { Model05 }\end{array}$ & $\begin{array}{r}(6) \\
\text { Modelo6 }\end{array}$ & $\begin{array}{r}(7) \\
\text { Model07 }\end{array}$ \\
\hline trabaja11 & $\begin{array}{l}-0.0737^{* *} \\
(-2.62)\end{array}$ & $\begin{array}{l}-0.0724^{*} \\
(-2.58)\end{array}$ & & & & & \\
\hline _Iestrato2_2 & $\begin{array}{l}0.0865^{* \frac{\hbar}{*}} \\
(2.82)\end{array}$ & $\begin{array}{l}0.0877^{* *} \\
(2.77)\end{array}$ & $\begin{array}{l}0.0700^{*} \\
(2.04)\end{array}$ & $\begin{array}{l}0.0685 \\
(1.96)\end{array}$ & $\begin{array}{l}0.0694^{*} \\
(2.04)\end{array}$ & & \\
\hline _Iestrato2_3 & $\begin{array}{l}0.0655 \\
(1.85)\end{array}$ & $\begin{array}{l}0.0599 \\
(1.67)\end{array}$ & $\begin{array}{l}0.0350 \\
(0.93)\end{array}$ & $\begin{array}{l}0.0177 \\
(0.47)\end{array}$ & $\begin{array}{l}0.0004 \\
(0.01)\end{array}$ & & \\
\hline edad & & $\begin{array}{l}0.0009 \\
(0.93)\end{array}$ & & $\begin{array}{l}0.0022 \\
(1.96)\end{array}$ & & & \\
\hline mujer & & $\begin{array}{l}0.0204 \\
(0.82)\end{array}$ & & $\begin{array}{l}0.0221 \\
(0.79)\end{array}$ & & & \\
\hline ingreso11 & & & $\begin{array}{l}-0.0000 * \\
(-2.39)\end{array}$ & $\begin{array}{l}-0.0000 * \\
(-2.56)\end{array}$ & $\begin{array}{l}-0.0000^{*} \\
(-2.35)\end{array}$ & $\begin{array}{l}-0.0000 * \\
(-2.14)\end{array}$ & $\begin{array}{l}-0.0000^{*} \\
(-2.07)\end{array}$ \\
\hline qhijos & & & & & $\begin{array}{l}0.0198 * * \\
(3.16)\end{array}$ & $\begin{array}{l}0.0144^{*} \\
(2.53)\end{array}$ & \\
\hline _Icredit_c 2 & & & & & & $\begin{array}{l}-0.0333 \\
(-0.65)\end{array}$ & \\
\hline _Icredit_c 3 & & & & & & $\begin{array}{l}0.1071^{*} \\
(2.33)\end{array}$ & \\
\hline preocupa11 & & & & & & & $\begin{array}{l}0.0957^{*} \\
(2.20)\end{array}$ \\
\hline _cons & $\begin{array}{l}0.4047^{* * * *} \\
(11.62)\end{array}$ & $\begin{array}{l}0.3594^{* * *} \\
(6.74)\end{array}$ & $\begin{array}{l}0.3988 * * * \\
(10.94)\end{array}$ & $\begin{array}{l}0.3123^{* * *} \\
(5.47)\end{array}$ & $\begin{array}{l}0.3681^{* * *} \\
(9.82)\end{array}$ & $\begin{array}{l}0.3440^{* \pi * 4} \\
(7.17)\end{array}$ & $\begin{array}{l}0.3592^{* *} * \\
(8.06)\end{array}$ \\
\hline $\begin{array}{l}\mathrm{N} \\
\mathrm{r} 2 \\
\mathrm{~F}\end{array}$ & $\begin{array}{r}311 \\
0.0588 \\
6.8651\end{array}$ & $\begin{array}{r}305 \\
0.0625 \\
4.2856\end{array}$ & $\begin{array}{r}271 \\
0.0465 \\
5.2792\end{array}$ & $\begin{array}{r}266 \\
0.0641 \\
4.2964\end{array}$ & $\begin{array}{r}270 \\
0.0739 \\
6.9001\end{array}$ & $\begin{array}{r}260 \\
0.1296 \\
11.4703\end{array}$ & $\begin{array}{r}147 \\
0.0628 \\
5.3512\end{array}$ \\
\hline
\end{tabular}

t statistics in parentheses

* $p<0.05$, ** $p<0.01$, *** $p<0.001$

Las estimaciones arrojan como resultado que las personas que estaban trabajando en 2011 tuvieron una reacción menos intensa (e. g., una menor cantidad declaró que redujeron su consumo de bienes y servicios). Asimismo, las personas con mayores ingresos en 2011 fueron las que menor reacción negativa exhibieron ante la crisis. Los dominicanos que viven en España tuvieron una reacción ante la crisis mayor que los que viven en los Estados Unidos y en Puerto Rico. La edad ni el género tienen una influencia significativa en la reacción ante la crisis, pero la cantidad de hijos si influyó en el cambio del patrón de consumo ante la crisis económica. La restricción crediticia -para aquellos que piensan que en 2011 era 
más difícil obtener un préstamo- impactó sobre el comportamiento de los dominicanos ante la crisis. Por último, los dominicanos con mayor preocupación de perder su empleo fueron más propensos a modificar su patrón de consumo ante la recesión y el desempleo.

\section{¿AHORA ES MÁS FÁCIL O MÁS DIFÍCIL LOGRAR LOS SUEÑOS DEL MIGRANTE?}

Una de las razones por la cual existe un alto incentivo para emigrar hacia otro país es para lograr el sueño de conseguir un trabajo estable, vivienda propia, ayudar a la familia, entre otros aspectos. $\mathrm{Al}$ evaluar la percepción que tienen los entrevistados respecto al grado de dificultad de lograr hoy día ese sueño, se observa que la mayoría indicó que ahora es más difícil que antes. Lo anterior es transversal en los tres países de residencia. A priori, se esperaría verificar una significativa diferencia en la percepción de quienes no estaban trabajando versus quienes sí lo estaban. Sin embargo, no es el caso, siendo la proporción similar. El $82 \%$ de los que no trabajan indicó que es más difícil versus $85 \%$ de los que sí trabajan.

Aun cuando existe una alta percepción de que ahora es más difícil lograr el sueño del migrante, los emigrantes dominicanos prefieren continuar residiendo en el exterior e incluso le recomendarían a un amigo o familiar a emigrar. A nivel global, el 57.6\% de los entrevistados declaró volver a emigrar si tuviera que hacerlo nuevamente por primera vez. A pesar que la mayoría volvería a hacerlo, existen diferencias por países. Los que residen en España son los que tendrían mayor propensión a quedarse en la República Dominicana. 


\section{Gráfico N. ${ }^{\circ} 26$}

Percepción sobre dificultad de lograr ahora el sueño del emigrante

EE. UU.

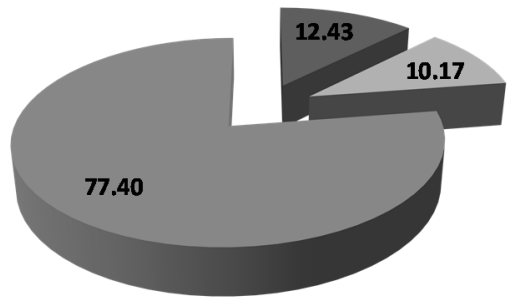

— Ahora es más fácil Es lo mismo que antes $\quad$ Ahora es más difícil

\section{España}

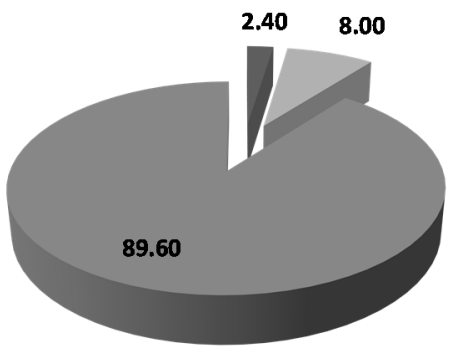

¿Ahora es más fácil Es lo mismo que antes $\quad$ Ahora es más difícil

\section{Puerto Rico}

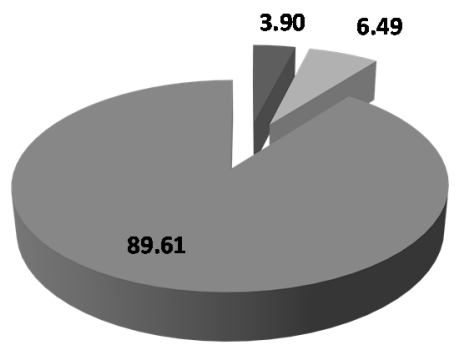

— Ahora es más fácil Es lo mismo que antes a Ahora es más difícil 
Tabla N. ${ }^{\circ} 19$

¿Si tuviera que decidir emigrar por primera vez nuevamente, lo haría? Por país de residencia

\begin{tabular}{|lrrrr|} 
& EE.UU. & España & Puerto Rico & \multicolumn{1}{c|}{ Total } \\
\hline Volvería a migrar & 62.9 & 46.8 & 63.5 & 57.6 \\
\hline Me quedaría en RD & 28.6 & 35.7 & 35.1 & 32.3 \\
\hline No sé & 8.6 & 17.5 & 1.4 & 10.1 \\
\hline Total & $\mathbf{1 0 0 . 0}$ & $\mathbf{1 0 0 . 0}$ & $\mathbf{1 0 0 . 0}$ & $\mathbf{1 0 0 . 0}$ \\
\hline
\end{tabular}

De hecho, los residentes en España fueron los únicos que recomendarían a sus amigos a no emigrar (61.1\% de los entrevistados) mientras que EE. UU. y Puerto Rico sí lo recomendarían (64.2\% y $51.3 \%$, respectivamente). Este resultado se explica en parte por el hecho de que los dominicanos en España muestran una mayor tasa de desempleo y quienes a su vez presentaron mayores pérdidas de empleo entre 2008 y 2011.

La voluntad de emigrar depende también de la condición laboral de la persona en el país receptor. En ese contexto, los que están trabajando en el exterior son los que responden que volverían a emigrar. Mientras, aquellos que no tienen un empleo son los que presentan menor voluntad a volver a emigrar.

Tabla N. ${ }^{\circ} 20$

¿Si tuviera que decidir emigrar por primera vez nuevamente, lo haría? Por situación laboral

\begin{tabular}{|lrrr|} 
& No trabaja & Sí trabaja & \multicolumn{1}{c|}{ Total } \\
\hline Volvería a migrar & 45.0 & 64.2 & 57.6 \\
\hline Me quedaría en RD & 40.3 & 28.0 & 32.3 \\
\hline No sé & 14.7 & 7.7 & 10.1 \\
\hline Total & $\mathbf{1 0 0 . 0}$ & $\mathbf{1 0 0 . 0}$ & $\mathbf{1 0 0 . 0}$ \\
\hline
\end{tabular}




\subsubsection{Ecuación de Mincer - Retorno de la educación}

Becker (1962) y Mincer (1974) establecen que el ingreso laboral está positivamente relacionado a la educación y experiencia. Específicamente establecen lo siguiente:

$$
\log y=\beta_{0}+\beta_{1} e d u c+\beta_{2} \exp +\beta_{3} \exp ^{2},
$$

Donde $\beta_{1}$ representa la tasa de retorno de la educación

En esta misma línea, se especificó una ecuación de Mincer para evaluar la relación con el ingreso percibido de los años de educación, el género, la edad y residir en España o Puerto Rico relativo a Estados Unidos. De lo anterior se construyó el siguiente modelo:

$$
\begin{aligned}
\log y=\beta_{0}+ & \beta_{1} \text { educación }+\beta_{2} \text { mujer }+\beta_{3} \text { edad } \\
& +\beta_{4} \text { edad }{ }^{2}+\beta_{5} \text { _lestrato2_2 } \\
& +\beta_{6} \text { _Iestrato2_3 }
\end{aligned}
$$

Donde:

$\mathrm{y}=$ ingresos mensuales

Educación ${ }^{55}=$ años de escolaridad

Mujer $=$ variable dicotómica sexo $(1=$ mujer $/ 0=$ hombre $)$

Edad $=$ edad del entrevistado

_Iestrato2_2 = Residir en España

_Iestrato2_3 = Residir en Puerto Rico

En la tabla N. ${ }^{\circ} 21$ se presentan los resultados las ecuaciones de Mincer estimadas. El modelo 1 revela que los años de escolaridad (gráfico N. ${ }^{\circ} 27$ ) se relacionan positivamente con el ingreso. El coeficiente de retorno de la educación permite señalar que por cada año de escolaridad adicional el ingreso se incrementa en 5.7\%. En cuanto a la edad, se observa que el ingreso crece con la edad hasta alcanzar un punto de inflexión a partir del cual comienza a decrecer, verificándose el ciclo de vida. La edad promedio a partir de la cual el ingreso comienza a decrecer es 47 años.

\footnotetext{
55 Se construyó una variable continua con los años de educación a partir de las respuestas obtenidas del nivel máximo de educación.
} 
El impacto de la Gran Recesión sobre los migrantes dominicanos

Tabla N. ${ }^{\circ} 21$

Ecuaciones de Mincer de dominicanos migrantes

\begin{tabular}{|c|c|c|}
\hline & Modelo 1 & Modelo 2 \\
\hline Educación & $\begin{array}{l}0.057 \text { *** } \\
(5.484)\end{array}$ & $\begin{array}{l}0.071^{* * *} \\
(6.794)\end{array}$ \\
\hline Mujer & $\begin{array}{l}-0.216^{* * *} \\
(-2.657)\end{array}$ & $\begin{array}{l}-0.215^{* * *} \\
(-2.647)\end{array}$ \\
\hline Edad & $\begin{array}{l}0.108^{* * *} \\
(5.793)\end{array}$ & $\begin{array}{l}0.108^{* * *} \\
(5.744)\end{array}$ \\
\hline Edad2 & $\begin{array}{l}-0.001 \text { *** } \\
(-5.478)\end{array}$ & $\begin{array}{l}-0.001 * * * \\
(-5.394)\end{array}$ \\
\hline EE. UU. & $\begin{array}{r}0.000 \\
(.)\end{array}$ & \\
\hline España & $\begin{array}{l}-0.435^{* * *} \\
(-4.841)\end{array}$ & \\
\hline Puerto Rico & $\begin{array}{l}-0.218^{* *} \\
(-2.228)\end{array}$ & \\
\hline EE. UU. \#Educación & & $\begin{array}{r}0.000 \\
(.)\end{array}$ \\
\hline España \#Educación & & $\begin{array}{l}-0.028^{* * *} \\
(-4.741)\end{array}$ \\
\hline Puerto Rico \#Educación & & $\begin{array}{l}-0.016 \text { ** } \\
(-2.137)\end{array}$ \\
\hline Constant & $\begin{array}{l}4.446^{* * *} \\
(9.622)\end{array}$ & $\begin{array}{l}4.240^{* * * *} \\
(9.387)\end{array}$ \\
\hline Observations & 322 & 322 \\
\hline Adjusted R-squared & 0.274 & 0.273 \\
\hline
\end{tabular}

$\mathrm{t}$ statistics in parentheses

${ }^{*} \mathrm{p}<0.10,{ }^{* *} \mathrm{p}<0.05,{ }^{* * *} \mathrm{p}<0.01$ 


\section{Gráfico N. ${ }^{\circ} 27$ \\ Ingreso mensual según años de escolaridad}

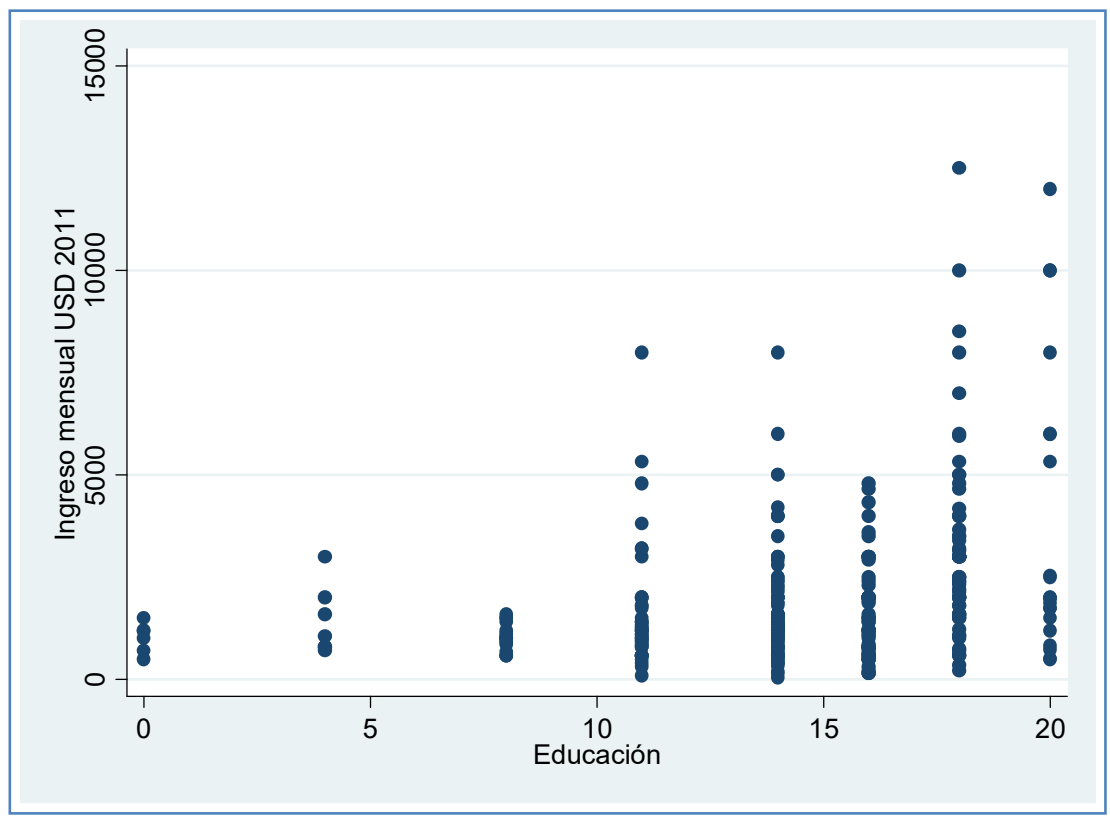

Adicionalmente, en el gráfico N. ${ }^{\circ} 28$ se observa que, aun cuando el ciclo de vida se mantiene independientemente del nivel de educación, aquellos con educación universitaria perciben mayores ingresos. Con relación al género, la mujer percibe un ingreso $21.7 \%$ menor al del hombre, ${ }^{56}$ lo cual sugiere la existencia de discriminación de género. En el modelo 1 se observa que los emigrantes dominicanos residentes en España y Puerto Rico reciben un menor nivel de ingreso que aquellos que residen en los Estados Unidos.

${ }^{56}$ Controlando por el nivel educativo.

546 Ciencia y Sociedad 2015; 40(3): 477-563 
El impacto de la Gran Recesión sobre los migrantes dominicanos

Gráfico N. ${ }^{\circ} 28$

Ingreso mensual por edad según educación (secundaria y universitaria) y sexo
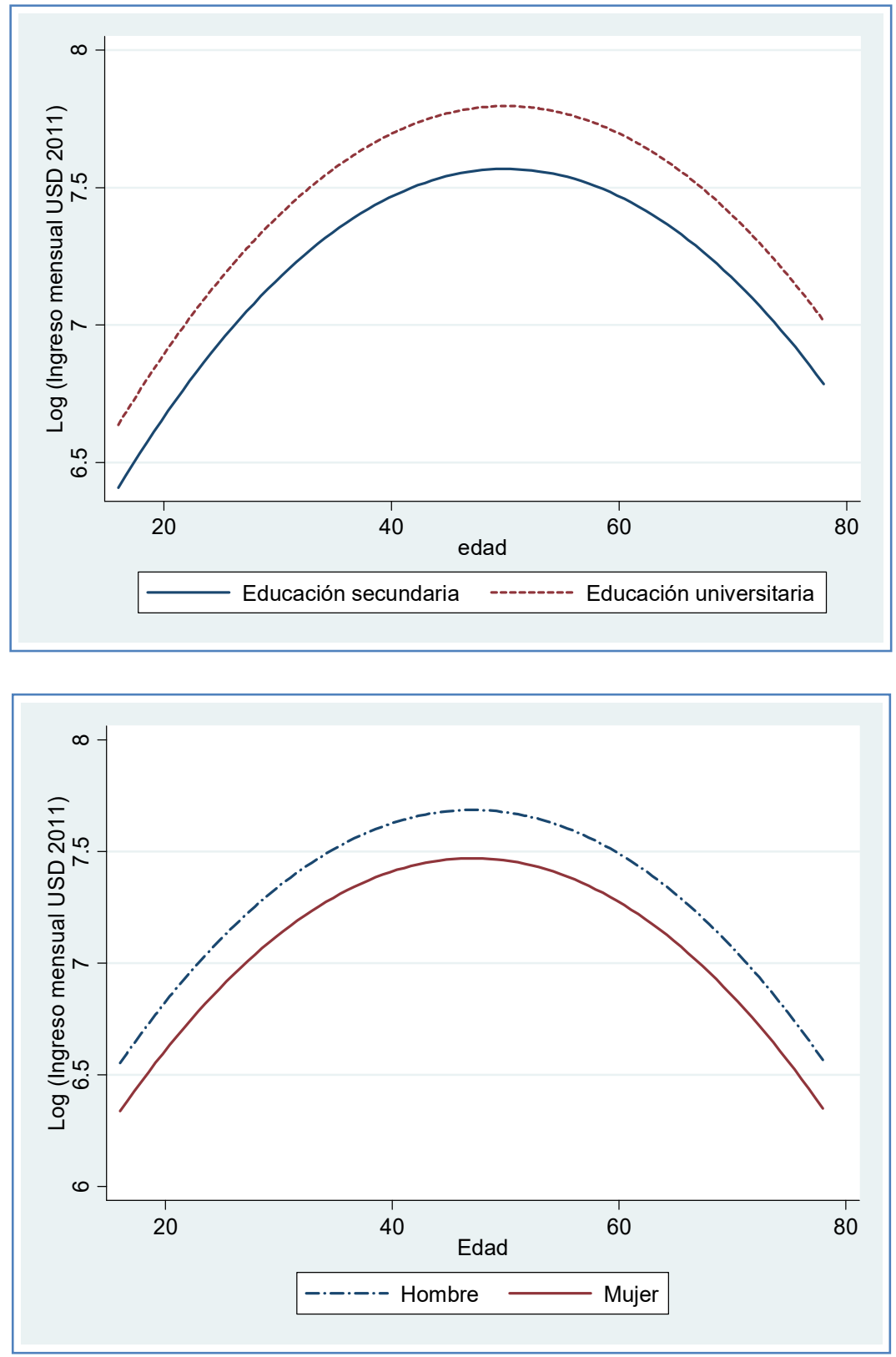

Ciencia y Sociedad 2015; 40(3): 477-563 547 
El modelo 2 presentado en la tabla $\mathrm{N} .^{\circ} 21$ presenta los resultados de incluir la interacción entre la educación y el estrato. ${ }^{57}$ Los Estados Unidos constituyen el país de referencia por lo cual el valor del coeficiente que acompaña a la variable de educación sugiere que el retorno de la educación de los dominicanos en ese territorio es de $7.1 \%$. Al tomar en consideración los efectos de la interacción se obtiene como resultado que el retorno de la educación en España es de 4.3\%; es decir, 2.8 puntos porcentuales menor al de los Estados Unidos. Y en el caso de Puerto Rico, el retorno de la educación es de 5.5\% (i.e., 1.6 puntos porcentuales menor al que se obtiene en los Estados Unidos.)

Estos resultados son consistentes con la respuesta de los migrantes dominicanos con relación a si volverían a salir de la República Dominicana. Los que viven en España, que tienen un menor retorno por cada año de educación son los que en menor proporción afirman que volverían a emigrar.

\subsubsection{Impacto sobre las remesas}

\section{¿LA CRISIS FINANCIERA DISMINUYÓ LA CAPACIDAD DE ENVÍO DE REMESAS?}

\section{Análisis micro}

Se evidencia que el dominicano residente en el exterior envía remesas periódicamente a sus familiares. Sin embargo, entre 2008 y 2011, el porcentaje de población que envía remesas bajó de $54.4 \%$ a un 48.0\%. En el caso de España, la proporción pasó de 57.3\% en 2008 a 46.8\% en el año 2011. En Puerto Rico, pasó de 79.2\% a $62.2 \%$, en el mismo período, siendo el país con mayor caída en la proporción de personas que envían remesas. Para el caso de Estados Unidos, la proporción se incrementó ligeramente, pasando de un $41.5 \%$ a un $42.6 \%$.

\footnotetext{
57 La introducción de este efecto interacción fue sugerida por Pozo (2015).
} 
La mayor proporción envía remesas con frecuencia mensual. Se observa un cambio hacia envíos menos frecuentes en 2011 respecto a años previo a la crisis económica. En 2008, el 72.3\% de los dominicanos enviaba remesas mensualmente a sus familiares. En 2011, ese porcentaje bajó a $61.8 \%$, pasando el porcentaje de envíos ocasionales de $8.9 \%$ (2008) a 13.5\% (2011). El mayor cambio se produjo en España, donde previo a la crisis el $53.5 \%$ enviaba remesas con frecuencia mensual o menos y en 2011 solo lo hizo el 27.6\%.

En el 2008 enviaban un promedio de 277 dólares mensuales versus 259 dólares mensuales para el 2011. En términos reales, descontando tres años con una tasa de inflación promedio de un $2 \%$, esa variación significa un descenso de un 12\%. ¿Qué explica la reducción en el monto enviado de remesas de acuerdo a los entrevistados? La situación económica y la menor disponibilidad de ingresos son los principales factores que explican el descenso de las remesas. Alineado con la situación de empleo vigente en España, en ese país existe una mayor proporción de personas que declaran enviar menos debido a que no tiene empleo (30\%). Para el caso de Estados Unidos y Puerto Rico, las proporciones son $5.7 \%$ y $3.6 \%$, respectivamente.

Se corrieron varios modelos logit para evaluar los principales elementos micro que influyen sobre la probabilidad de enviar remesas. Los resultados (tabla $\mathrm{N}^{\circ}$ 22) revelan que el principal elemento que influye sobre la probabilidad de enviar remesas es la condición laboral. La probabilidad de enviar remesas depende del estatus laboral. Los dominicanos residentes en España y en Puerto Rico tienen más probabilidad de enviar remesas a sus familiares. El tiempo de residencia no tiene una influencia significativa sobre la probabilidad de enviar remesas. El más educado tiene menor probabilidad de enviar remesas. Lo anterior es consistente con el hecho de que a mayor educación mayor es la probabilidad de que la familia residente en la República Dominicana no sea de escasos recursos. A mayor edad, aumenta la probabilidad de enviar remesas, pero hasta cierta edad, a partir de la cual comienza a reducirse. La 
mujer tiene mayor probabilidad de enviar remesas que el hombre. La cantidad de hijos dependientes influye positivamente sobre la probabilidad de enviar remesas. El vínculo de la crisis económica con los determinantes microeconómicos se manifiesta a través de la variable probabilidad de estar trabajando. Si la crisis económica reduce el empleo habría una disminución de las remesas enviadas por dominicanos hacia sus familiares en la República Dominicana.

Tabla N. ${ }^{\circ} 22$

Determinantes de remesas

Modelos determinantes remesas para casos con ingresos positivos en 2011

\begin{tabular}{|c|c|c|c|c|c|}
\hline & $\begin{array}{r}(1) \\
\text { Modelo1 }\end{array}$ & $\begin{array}{r}(2) \\
\text { Modelo2 }\end{array}$ & $\begin{array}{r}\text { (3) } \\
\text { Modelo3 }\end{array}$ & $\begin{array}{r}\text { (4) } \\
\text { Mode104 }\end{array}$ & $\begin{array}{r}(5) \\
\text { Mode } 105\end{array}$ \\
\hline trabaja11 & $\begin{array}{l}2.0471^{* * *} \\
(6.86)\end{array}$ & $\begin{array}{l}2.1001^{* * *} \\
(6.77)\end{array}$ & $\begin{array}{l}2.0853^{* * *} \\
(6.34)\end{array}$ & & $\begin{array}{l}2.1427^{* * * *} \\
(7.00)\end{array}$ \\
\hline _Iestrato2_2 & & $\begin{array}{l}0.6469^{*} \\
(2.27)\end{array}$ & & & \\
\hline _Iestrato2_3 & & $\begin{array}{l}0.6296^{*} \\
(2.06)\end{array}$ & & & \\
\hline tiempo & & & $\begin{array}{l}-0.0158 \\
(-0.41)\end{array}$ & & \\
\hline tiempo2 & & & $\begin{array}{l}0.0002 \\
(0.17)\end{array}$ & & \\
\hline educacion & & & & $\begin{array}{l}-0.0937^{*} \\
(-2.58)\end{array}$ & \\
\hline edad & & & & $\begin{array}{l}0.1829 * * * \\
(3.83)\end{array}$ & \\
\hline edad2 & & & & $\begin{array}{l}-0.0019 * * * \\
(-3.41)\end{array}$ & \\
\hline mujer & & & & $\begin{array}{l}-0.4598^{*} \\
(-1.97)\end{array}$ & \\
\hline qhijos & & & & & $\begin{array}{l}0.2699 * \\
(2.03)\end{array}$ \\
\hline _cons & $\begin{array}{l}-1.5235^{* * *} \\
(-5.68)\end{array}$ & $\begin{array}{l}-1.8954^{* * *} \\
(-6.03)\end{array}$ & $\begin{array}{l}-1.4172^{* * *} \\
(-4.94)\end{array}$ & $\begin{array}{l}-2.3497^{*} \\
(-2.29)\end{array}$ & $\begin{array}{l}-2.0972^{* * *} \\
(-5.61)\end{array}$ \\
\hline $\begin{array}{l}\mathrm{N} \\
\text { r2_p } \\
\text { chi2 }\end{array}$ & $\begin{array}{r}345 \\
0.1233 \\
47.0788\end{array}$ & $\begin{array}{r}345 \\
0.1385 \\
66.2341\end{array}$ & $\begin{array}{r}342 \\
0.1230 \\
45.2936\end{array}$ & $\begin{array}{r}333 \\
0.0741 \\
27.4563\end{array}$ & $\begin{array}{r}344 \\
0.1591 \\
49.6823\end{array}$ \\
\hline
\end{tabular}

550 Ciencia y Sociedad 2015; 40(3): 477-563 


\section{Análisis macro}

Las remesas arrojaron una tasa de crecimiento de un 5.8\% entre 2000 y 2012, pasando de 1,689 millones de dólares a 3,158.1 millones de dólares. La siguiente gráfica revela la existencia de una estrecha correlación entre la evolución de las remesas y del PIB de los Estados Unidos y de España -cuantificadas las tres variables como desviaciones (logarítmicas) respecto a sus tendencias-.

Gráfico N. ${ }^{\circ} 29$

Remesas, PIB de EE.UU. y España

(Desviación respecto a su tendencia en logs)

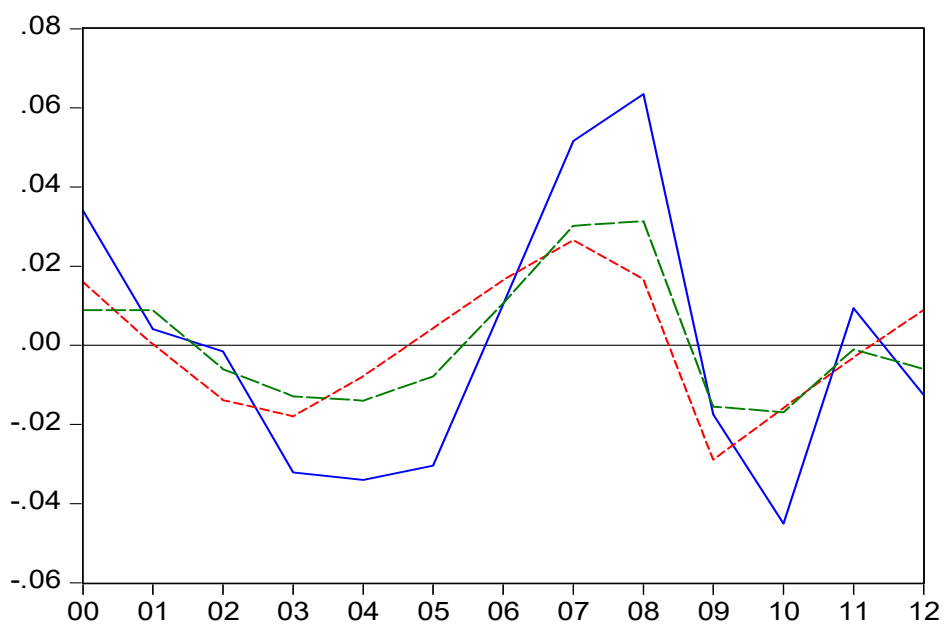

Remesas ----- PIB EEUU --- PIB España

Se estimó un modelo econométrico [ver anexo 5] para cuantificar el impacto de la desviación del PIB respecto de su tendencia en España y en los Estados Unidos sobre las remesas familiares recibidas en la República Dominicana. Dada la estrecha correlación entre ambas variables explicativas se decidió realizar estimaciones econométricas separadas de las remesas en función del PIB español y del PIB estadounidense. Los resultados sugieren que la desviación del PIB español respecto a su tendencia explica mejor la desviación de las remesas con relación a su tendencia. 


\author{
Gráfico N. ${ }^{\circ} 30$
}

Remesas explicadas por PIB - España y EE.UU.

Re mesas explicadas por el PIB español (Desviación respecto a su tendencia en logs)

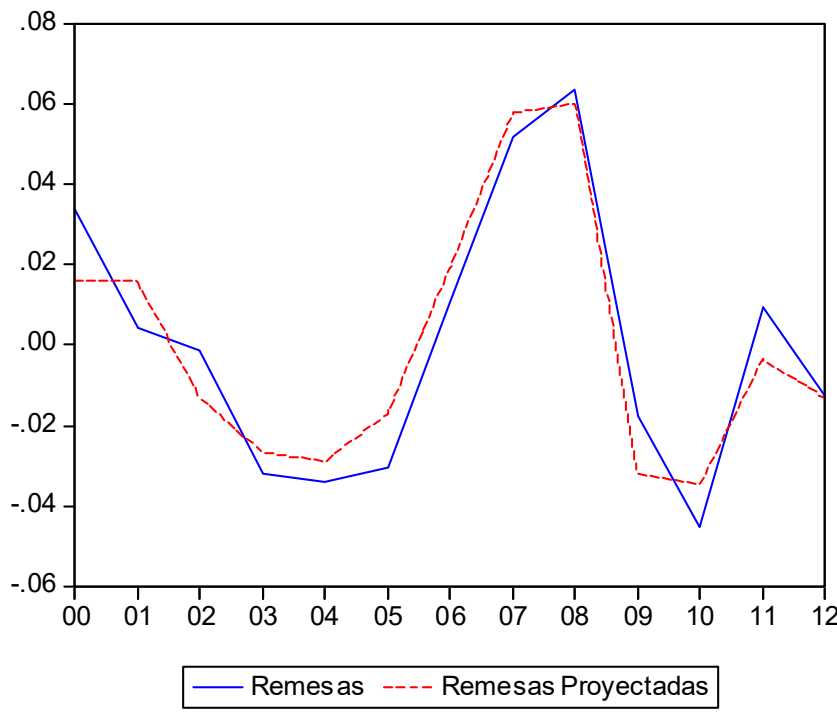

Remesas explicadas por el PIB de EEUU (Desviación respecto a su tendencia en logs)

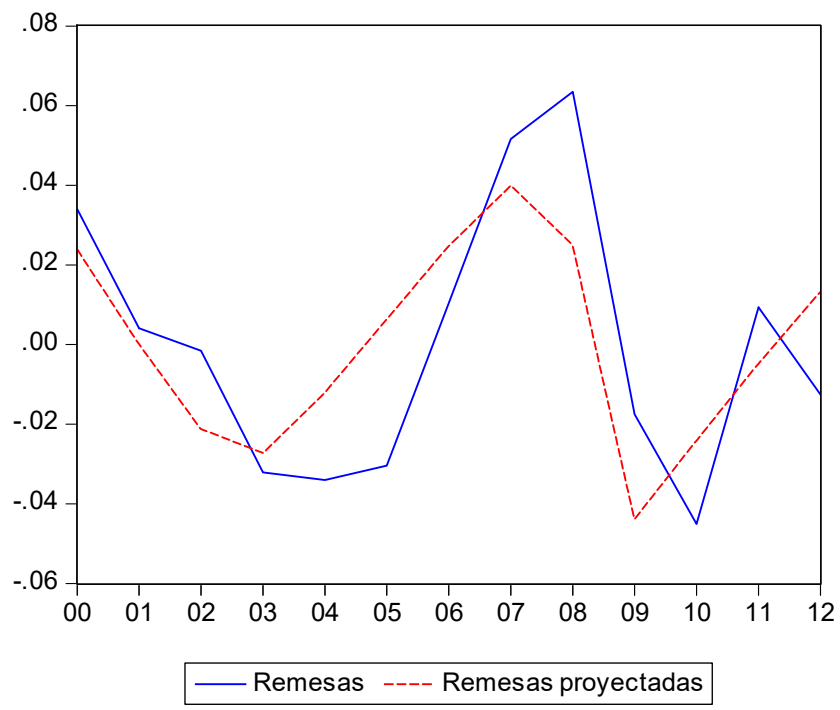

552 Ciencia y Sociedad 2015; 40(3): 477-563 


\section{Conclusiones}

La Gran Recesión tuvo un impacto negativo sobre los dominicanos residentes en el exterior, en particular en España. Ese impacto se manifestó principalmente por la pérdida de ingreso laboral real de los dominicanos emigrantes, producto de un mayor desempleo y menor remuneración por hora. ${ }^{58}$

La baja propensión a ser propietarios de viviendas evitó que la crisis financiera deteriorase significativamente la riqueza de los emigrantes dominicanos. A pesar de la crisis, algunos dominicanos lograron adquirir una vivienda.

La pérdida de empleo o la percepción de perder el empleo hizo que los dominicanos residentes en el exterior modificaran su patrón de consumo. Se observa cómo los dominicanos redujeron el consumo superfluo, pero no la inversión en educación. El mayor retorno a la educación es percibido en los Estados Unidos y el menor en España.

Los modelos econométricos cuantificaron el impacto negativo de la crisis económica sobre la capacidad de envío de las remesas entre 2008 y 2011. Se observa que cuando los Estados Unidos y España disminuyen su ritmo de crecimiento económico se contrae la capacidad de envío de remesas hacia la República Dominicana. A nivel micro se cuantificó que el deterioro del mercado laboral

58 Los resultados de una muestra tan pequeña siempre deben tomarse con cautela. Pozo (2015) comenta sobre la posibilidad de que exista sesgo muestral que pueda afectar los resultados. Ella utiliza datos del Censo de Migrantes de los dominicanos en Nueva York y New Jersey y obtiene que entre 2008 y 2011 el ingreso promedio de esa población aumentó en un $7.4 \%$ en términos reales. Sin embargo, también obtiene que en ese período la tasa de desempleo de los dominicanos aumentó de 5.5\% a 7.2\% y que la tasa de participación laboral se redujo de $69.4 \%$ a $68.4 \%$. Estos últimos datos sobre el mercado laboral guardan una mayor consistencia con el efecto esperado que tendría la Gran Recesión sobre los migrantes dominicanos y con las conclusiones obtenidas en la presente investigación. 
afecta negativamente la probabilidad de que los dominicanos emigrantes puedan enviar remesas a sus familiares en el territorio dominicano.

Dada la relación económica que existe entre la República Dominicana y su población emigrante, una disminución en la calidad de vida de esta influye negativamente en los dominicanos residentes en el país.

A pesar de la crisis, el dominicano emigrante volvería a salir del país. El dominicano residente en España es el que menos voluntad tendría de volver a emigrar. Esto se relaciona con el mayor deterioro de las condiciones laborales de la economía española con relación a los Estados Unidos y a Puerto Rico.

Esto confirma la afirmación de que, a pesar de la crisis económica del país receptor, la República Dominicana es un país de emigrantes, que mantiene estrechos vínculos económicos con sus familiares que permanecen en el territorio dominicano. 


\section{Anexos}

\subsection{Análisis de varianza horas trabajadas}

oneway horas11 mujer, tab

\begin{tabular}{r|rrr} 
& \multicolumn{3}{|c}{ Summary of horas11 } \\
Mujer & Mean & Std. Dev. & Freq. \\
\hline No & 45.294574 & 12.9388 & 129 \\
Si & 41.54902 & 10.160716 & 102 \\
\hline Tota1 & 43.640693 & 11.915495 & 231
\end{tabular}

\begin{tabular}{ccrcrr} 
& \multicolumn{2}{c}{ Analysis of Variance } & & \\
Source & SS & df & MS & F & Prob > F \\
\hline $\begin{array}{c}\text { Between groups } \\
\text { Within groups }\end{array}$ & 799.116386 & 1 & 799.116386 & 5.74 & 0.0173 \\
\hline Total & 31856.0611 & 229 & 139.109437 & & \\
\hline 32655.1775 & 230 & 141.979033 & &
\end{tabular}

Bartlett's test for equal variances: $\operatorname{chi2}(1)=6.3845$ Prob $>$ chi2 $=0.012$

\subsection{Prueba de medias (ttest) con varianzas desiguales}

ttest horas11, by(mujer) unequal leve1(95)

Two-sample t test with unequal variances

\begin{tabular}{|c|c|c|c|c|c|c|}
\hline Group & obs & Mean & Std. Err. & Std. Dev. & [95\% Conf. & Interval] \\
\hline $\begin{array}{l}\text { No } \\
\text { Si }\end{array}$ & $\begin{array}{l}129 \\
102\end{array}$ & $\begin{array}{l}45.29457 \\
41.54902\end{array}$ & $\begin{array}{l}1.139198 \\
1.006061\end{array}$ & $\begin{array}{r}12.9388 \\
10.16072\end{array}$ & $\begin{array}{l}43.04048 \\
39.55327\end{array}$ & $\begin{array}{l}47.54867 \\
43.54477\end{array}$ \\
\hline combined & 231 & 43.64069 & .783982 & 11.9155 & 42.09599 & 45.1854 \\
\hline diff & & 3.745554 & 1.519845 & & .7508847 & 6.740223 \\
\hline \multicolumn{3}{|c|}{$\operatorname{diff}=\operatorname{mean}(\mathrm{No})-\operatorname{mean}(\mathrm{Si})$} & \multicolumn{4}{|c|}{$\begin{aligned} \mathrm{t} & =2.4644 \\
\text { tom } & =228.992\end{aligned}$} \\
\hline \multicolumn{2}{|c|}{$\begin{array}{c}\text { Ha: } \operatorname{diff}<0 \\
\operatorname{Pr}(T<t)=0.9928\end{array}$} & \multicolumn{3}{|c|}{$\begin{array}{c}\text { Ha: diff } !=0 \\
\operatorname{Pr}(|T|>|t|)=0.0145\end{array}$} & \multicolumn{2}{|c|}{$\begin{array}{c}\text { Ha: diff }>0 \\
\operatorname{Pr}(T>t)=0.0072\end{array}$} \\
\hline
\end{tabular}




\subsection{Prueba de diferencia de media cantidad de horas no trabajadas no calificados y calificados}

Two-sample $t$ test with unequal variances

\begin{tabular}{|c|c|c|c|c|c|c|}
\hline Group & obs & Mean & Std. Err. & Std. Dev. & [90\% Conf. & Interval] \\
\hline $\begin{array}{l}\text { No calif } \\
\text { Califica }\end{array}$ & $\begin{array}{l}122 \\
104\end{array}$ & $\begin{array}{l}42.59836 \\
44.68269\end{array}$ & $\begin{array}{r}1.07758 \\
1.182021\end{array}$ & $\begin{array}{r}11.90226 \\
12.0543\end{array}$ & $\begin{array}{l}40.81222 \\
42.72079\end{array}$ & $\begin{array}{r}44.3845 \\
46.64459\end{array}$ \\
\hline combined & 226 & 43.55752 & .7976336 & 11.99106 & 42.24011 & 44.87494 \\
\hline diff & & -2.084332 & 1.599485 & & -4.726506 & .5578423 \\
\hline $\begin{aligned} & \text { diff } \\
\text { Ho: } & \text { diff }\end{aligned}$ & & if) - $m \in$ & $\begin{array}{l}\text { Califica) } \\
\text { Satterthwa }\end{array}$ & Is deare & of freedom & $\begin{array}{l}=-1.3031 \\
=217.479\end{array}$ \\
\hline $\begin{array}{r}\text { Ha: } \\
\operatorname{Pr}(T<t\end{array}$ & $\begin{array}{l}0 \\
.0970\end{array}$ & $\operatorname{Pr}$ & $\begin{array}{l}\text { Ha: diff ! } \\
|>| t \mid)=\end{array}$ & 1939 & $\begin{array}{r}\text { Ha: } \\
\operatorname{Pr}(T>t\end{array}$ & $\begin{array}{l}\text { liff }>0 \\
:=0.9030\end{array}$ \\
\hline
\end{tabular}

\subsection{Modelo logístico multinomial satisfacción con los ingresos en función a estar trabajando en 2011}

Multinomial logistic regression

Log pseudolikelihood $=-432.19118$
Number of obs = wald chi2(3) = Prob $>$ chi2 $=$ Pseudo R2=

\begin{tabular}{|c|c|c|c|c|c|c|}
\hline satisfaccion & Coef. & $\begin{array}{l}\text { Robust } \\
\text { Std. Err. }\end{array}$ & $z$ & $P>|z|$ & [95\% Conf. & Interval] \\
\hline $\begin{array}{l}1 \text { trabaja11 } \\
\quad \text { _cons }\end{array}$ & $\begin{array}{l}-.2905351 \\
-.4795731\end{array}$ & $\begin{array}{l}.3927303 \\
.3534048\end{array}$ & $\begin{array}{l}-0.74 \\
-1.36\end{array}$ & $\begin{array}{l}0.459 \\
0.175\end{array}$ & $\begin{array}{l}-1.060272 \\
-1.172234\end{array}$ & $\begin{array}{l}.4792021 \\
.2130875\end{array}$ \\
\hline $\begin{array}{r}\text { trabaja11 } \\
\text { _cons }\end{array}$ & $\begin{array}{r}-.9584479 \\
.5389965\end{array}$ & $\begin{array}{l}.3146749 \\
.2749735\end{array}$ & $\begin{array}{r}-3.05 \\
1.96\end{array}$ & $\begin{array}{l}0.002 \\
0.050\end{array}$ & $\begin{array}{r}-1.575199 \\
.0000584\end{array}$ & $\begin{array}{r}-.3416963 \\
1.077935\end{array}$ \\
\hline $\begin{array}{r}\text { trabaja11 } \\
\text { _cons }\end{array}$ & $\begin{array}{r}-3.023903 \\
.7396672\end{array}$ & $\begin{array}{l}.4135172 \\
.2656042\end{array}$ & $\begin{array}{r}-7.31 \\
2.78\end{array}$ & $\begin{array}{l}0.000 \\
0.005\end{array}$ & $\begin{array}{r}-3.834382 \\
.2190925\end{array}$ & $\begin{array}{r}-2.213424 \\
1.260242\end{array}$ \\
\hline
\end{tabular}

(satisfaccion $==2$ is the base outcome) 


\subsection{Modelos macroeconómicos de envío de remesas}

Dependent Variable: LREMESAS_C

Method: Least Squares

Date: 08/25/13 Time: 18:00

Sample: 20002012

Included observations: 13

\begin{tabular}{lrlrr}
\hline \hline \multicolumn{1}{c}{ Variable } & Coefficient & Std. Error & t-Statistic & Prob. \\
\hline \multicolumn{1}{c}{ C } & -0.001430 & 0.003186 & -0.448729 & 0.6623 \\
\multicolumn{1}{c}{ LPIB_S_C } & 1.960691 & 0.203463 & 9.636604 & 0.0000 \\
\hline \hline R-squared & 0.894092 & Mean dependent var & $-1.44 \mathrm{E}-05$ \\
Adjusted R-squared & 0.884464 & S.D. dependent var & 0.033759 \\
S.E. of regression & 0.011475 & Akaike info criterion & -5.956704 \\
Sum squared resid & 0.001448 & Schwarz criterion & -5.869789 \\
Log likelihood & 40.71858 & Hannan-Quinn criter. & -5.974569 \\
F-statistic & 92.86414 & Durbin-Watson stat & 2.307290 \\
Prob(F-statistic) & 0.000001 & & \\
\hline \hline
\end{tabular}

Dependent Variable: LREMESAS_C

Method: Least Squares

Date: 08/25/13 Time: 18:05

Sample: 20002012

Included observations: 13

\begin{tabular}{lrlrr}
\hline \hline \multicolumn{1}{c}{ Variable } & Coefficient & Std. Error & t-Statistic & Prob. \\
\hline \multicolumn{1}{c}{ C } & -0.000221 & 0.006582 & -0.033546 & 0.9738 \\
\multicolumn{1}{c}{ LPIB_US_C } & 1.509894 & 0.414220 & 3.645146 & 0.0039 \\
\hline \hline R-squared & 0.547084 & Mean dependent var & $-1.44 \mathrm{E}-05$ \\
Adjusted R-squared & 0.505910 & S.D. dependent var & 0.033759 \\
S.E. of regression & 0.023729 & Akaike info criterion & -4.503565 \\
Sum squared resid & 0.006194 & Schwarz criterion & -4.416650 \\
Log likelihood & 31.27317 & Hannan-Quinn criter. & -4.521430 \\
F-statistic & 13.28709 & Durbin-Watson stat & 1.375460 \\
Prob(F-statistic) & 0.003853 & & \\
\hline \hline
\end{tabular}




\section{Bibliografía}

Alarcón, R. et al. (2008). La crisis financiera en Estados Unidos y su impacto en la migración Mexicana. Recuperado de http://www. colef.mx/coyuntura/crisisfinanciera.pdf

Akerlof, G. (1970). The Market for "Lemons": Quality Uncertainty and the Market Mechanism. The Quarterly Journal of Economics, 84, 3, 488-500.

Aristy-Escuder, J. (2008). Flujos migratorios desde y hacia la República Dominicana. En A. Solimano. Migraciones Internacionales en América Latina. (pp. 395-448). México: Fondo de Cultura Económica.

Bean, C. (2009, 25 de agosto). The Great Moderation, the Great Panic and the Great Contraction." Annual Congress of the European Economic Association. (pp. 1-30). Barcelona.

Becker, G. (1962). Investment in human capital: a theoretical analysis. Journal of Political Economy, 70, 9-49.

Bernanke, B. (2013). The Federal Reserve and the Financial Crisis. (Lectures by Ben S. Bernanke). Princeton University Press.

Blinder, A. S. (1973). Wage Discrimination: Reduced From and Structural Estimates. The Journal of Human Resources, 8, 436-455.

Blinder, A. S. (2013). After the Music Stopped. The Financial Crisis, the Response, and the Work Ahead. Nueva York: The Penguin Books.

Camarota, S. \& Jensenius, K. (2009). Trends in Immigrant and Native Employment. Washington: Center for Immigration Studies.

Colectivo Ioé. (2012) Impactos de la crisis sobre la población inmigrante. Madrid: Organización Internacional para las Migraciones. 
Dehesa, G. De la. (2012). Spain and the Euro Area Sovereign Debt Crisis". En Cline, W. y G. Wolff (2012). Resolving the European Debt Crisis. (pp. 5-12). Washington: Peterson Institute for International Economics.

Duncan, N. \& B. Waldorf (2010), High Skilled Immigrant Recruitment and the Global Economic Crisis: The Effects of Immigration Policies. Indiana, EE. UU.: Purdue University.

Dustmann, C. et al. (2009). Employment, Wages and the Economic Cycle: Differences between Immigrants and Natives. London: Centre for Research and Analysis of Migration. [Discussion Paper N. $\left.{ }^{\circ} 09 / 06\right]$.

Estevão, M. \& Tsounta, E. (2011). Has the Great Recession Raised U.S. Structural Unemployment? [IMF Working Paper, WP/11/105]. Washington, D. C.: IMF

European Anti Poverty Network. (2012). Nuevas Propuestas para Nuevos Tiempos. Documento de EAPN-ES/ 2012. Barcelona: $\mathrm{El}$ autor.

Fligstein, N. \& Goldstein, A. (2011). The roots of the Great Recession. En D. Grusky (2011). The Great Recession. Nueva York: Russell Sage Foundation.

Hall, R. (2010). Why Does the Economy Fall to Pieces after a Financial Crisis? Journal of Economic Perspectives, 24, 4, 3-20.

Hernández, P. et al. (2011). An Estimate of the Potential Growth of the Spanish Economy. Documentos Ocasionales, N. 1104. España: Banco de España.

Hout, M., A. Levanon \& Cumberworth, E. (2011). Job Loss and Unemployment" en D. Grusky. The Great Recession. Nueva York: Russell Sage Foundation. 
Juan, A., De., Uría, F. \& Barrón, I., De. (2013). Anatomía de una Crisis. Cómo una mala gestión y la injerencia politica cambiaron la vida de todos y provocaron el rescate financiero. Deusto: Grupo Planeta.

Keeley, B. \& Love, P. (2010). From Crisis to Recovery. The Causes, Course and Consequences of the Great Recession. Paris: OECD Insights.

Mincer, J. (1974). Schooling, Experience and Earnings. New York: Columbia University Press.

Ministerio de Economía, Planificación y Desarrollo. (2011). Movimientos migratorios: desde y hacia la República Dominicana. (Tomo I y Tomo II). Santo Domingo: Fondo para el Fomento de la Investigación Económica y Social.

Mohapatra, S. \& D. Ratha (2010). Forecasting migrant remittances during the global financial crisis. Migration Letter, 7, 2, 9-20.

Oaxaca, R. (1973). Male-Female Wage Differentials in Urban Labor Markets. International Economic Review, 14. 693-705.

Orrenius, P. \& M. Zavodny (2009). Tied to the Business Cycle: How Immigrants Fare in Good and Bad Economic Times. Washington: Migration Policy Institute.

Papademetriou, D. \& Terrazas, A. (2009). Immigrants and the Current Economic Crisis: Research Evidence, Policy Challenges, and Implications. Washington: Migration Policy Institute.

Papademetriou, D. et al. (2010) Migration and Immigrants Two Years after the Financial Collapse: Where do We Stand? Washington: Migration Policy Institute and BBC World Service.

Pew Hispanic Center. (2010). Hispanics of Dominican Origin in the United States, 2008. Washington: Pew Research Center. 
Pew Hispanic Center. (2012). Hispanics of Dominican Origin in the United States, 2010. Washington: Pew Research Center.

Saenz, R. (2010). Latinos in the United States 2010. Washington: Population Reference Bureau.

Yang, D. (2004). Why Do Migrants Return to Poor Countries? Evidence from Philippine Migrants' Responses to Exchange Rate Shocks [Mimeo]. Michigan: University of Michigan.

Unites State Census Bureau. (2006). Hispanics in the United States. Washington: El Autor. 
P. S.: Agradezco la estrecha colaboración de Juan Pimentel y de Marina Ortiz. Así como el apoyo financiero del FIES para la realización de esta investigación. Todos los errores son de mi única responsabilidad. Este artículo fue presentado en el taller INTEC-Universidad de Londres The Dominican Republic's Economy celebrado en el Instituto de Estudios Latinoamericanos, Universidad de Londres, Reino Unido, el 7 de noviembre de 2014. Agradezco los comentarios de Susan Pozo y reitero que todo error queda bajo mi responsabilidad.

\section{Dr. Jaime Aristy-Escuder}

Es economista y matemático. En 1985 se graduó de licenciado en Economía mención de honor Summa Cum Laude en el Instituto Tecnológico de Santo Domingo. En 1989 recibió un doctorado en Economía de la Universidad de Barcelona, España. En 1994 obtuvo su título de magíster en Matemáticas Puras en la Pontificia Universidad Católica Madre y Maestra, (PUCMM). En 2003 se graduó de la Universidad de Chicago obteniendo un master of Science in Financial Mathematics.

Desde 1989 ha sido profesor de Economía Matemática y de Econometría en la PUCMM, INTEC y UNIBE, tanto en la maestría como a nivel de licenciatura. 
Entre 1994 y 2004 se desempeñó como director de Investigaciones de la Fundación Economía y Desarrollo. También ha sido consultor del PNUD, Banco Mundial, BID, Programa Mundial de Alimentos, UNICEF, CEPAL, y de la Agencia de los Estados Unidos para el Desarrollo Internacional, entre otras organizaciones.

El doctor Aristy Escuder ha escrito y colaborado en 10 libros publicados en la República Dominicana o por casas editoriales extranjeras, entre ellas el Fondo de Cultura Económica y McGraw-Hill. Además, es autor de varios ensayos sobre economía dominicana que han sido recogidos en revistas especializadas internacionales, algunos de los cuales han sido presentados en las Universidades de MIT, Harvard y de Londres.

En 1999 fue galardonado como Joven Sobresaliente por Jaycees'72 y en el 2011 recibió el premio de Egresado Destacado del INTEC. Es miembro de la American Economic Association y de la Econometric Society.

Recibido: 21-4-2015

Aprobado: 25-10-2015 
